\title{
MASTER
}

\section{A Survey of State Approaches To Solar Energy Incentives}

Steven B. Johnson
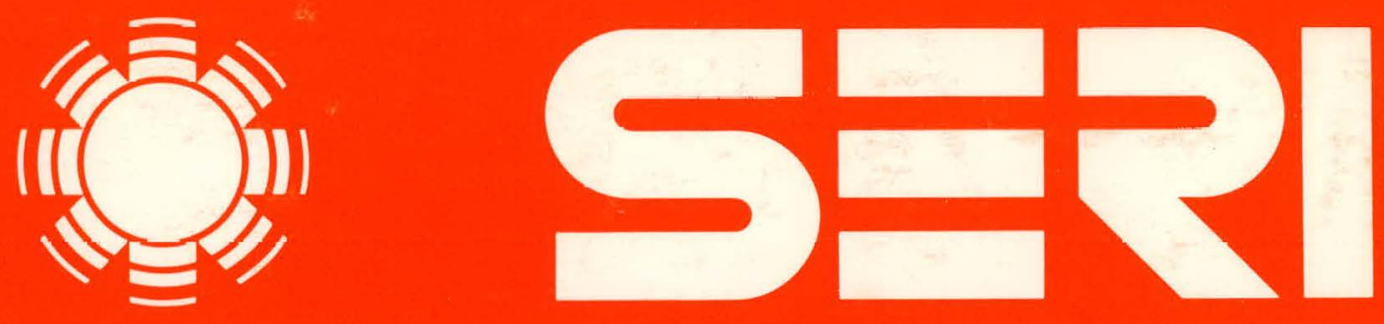

Solar Energy Research Institute

A Division of Midwest Research Institute

1536 Cole Boulevard

Golden, Colorado 80401

Operated for the

U.S. Department of Energy under Contract No. EG-77-C-01-4042

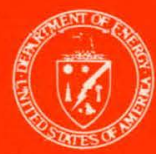




\section{DISCLAIMER}

This report was prepared as an account of work sponsored by an agency of the United States Government. Neither the United States Government nor any agency Thereof, nor any of their employees, makes any warranty, express or implied, or assumes any legal liability or responsibility for the accuracy, completeness, or usefulness of any information, apparatus, product, or process disclosed, or represents that its use would not infringe privately owned rights. Reference herein to any specific commercial product, process, or service by trade name, trademark, manufacturer, or otherwise does not necessarily constitute or imply its endorsement, recommendation, or favoring by the United States Government or any agency thereof. The views and opinions of authors expressed herein do not necessarily state or reflect those of the United States Government or any agency thereof. 


\section{DISCLAIMER}

Portions of this document may be illegible in electronic image products. Images are produced from the best available original document. 


\author{
Printed in the United States of America \\ Available from: \\ National Technical Information Service \\ U.S. Department of Commerce \\ 5285 Port Royal Road \\ Springfield, VA 22161 \\ Price: \\ Microfiche $\$ 3.00$ \\ Printed Copy $\$ 6.50$
}

\title{
NOTICE
}

This report was prepared as an account of rork sponsored by the United States Government. Neither the United States nor the United States Department of Energy, nor any of their employees, nor any of their contractors, subcontractors, or their employees, makes any warranty, express or implied, or assumes any legal liability or responsibility for the accuracy, completeness or usefulness of any information, apparatus, product or process disclosed, or represents that its use would not infringe privately owned rights. 
SER I /TR-62-265

UC CATEGORY: UC-59

A SURVEY OF STATE APPROACHES

TO SOLAR ENERGY INCENTIVES

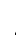

STEVEN B. JOHNSON

JULY 1979

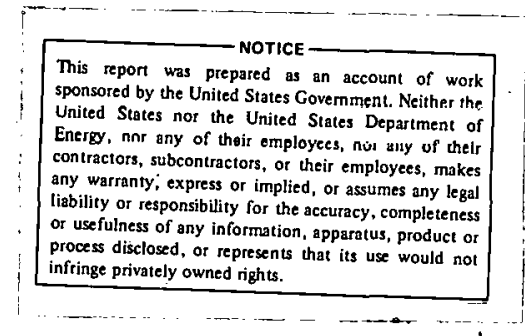

Solar Energy Research Institute

1536 Cole Boulevard

Gniden, Colnrado 80401

A Division oi Midwest Research Institute

Prepared for the

U.S. Department of Energy

ContractNo. EG.77. C. $01 \cdot 4042$ 
THIS PAGE

\section{WAS INTENTIONALLY \\ LEFT BLANK}




\section{FOREWORD}

This paper on state approaches to solar energy incentives was prepared by the Solar Energy Research Institute (SERI) to fulfill, in part, SERI's solar information dissemination function. The paper is part of the Market Development Branch Law Program, which in turn is part of the overall program of the Technology Commercialization Division.

This is the sixth of eight 1978 Summer Law Intern Papers sponsored by the SERI Law Program. The other seven address (1) the impact of the antitrust laws on the commercialization of solar heating and cooling, (2) licensing arrangements and the development of the solar energy industry, (3) problems in the administration of state solar legislation, (4) legal and institutional implications of providing financial incentives to encourage the development of solar energy technologies, (5) legal considerations in the development and implementation of biomass energy technologies, (6) land-use barriers and incentives to the use of solar energy, and (7) utility rates and service policies as potential barriers to the market penetration of decentralized solar technologies. These eight studies are meant to raise and discuss the primary legal issues that are, or will be, generated by the commercialization of solar technologies.

The author of this paper, Steven Johnson, was a student at the University of Colorado Law School while he was participating in the 1978 Summer Law Intern program. He is now a third-year student at the University of Colorado Law School. This paper has previously appeared, in edited form, as an article in Volume 1 of the Solar Law Reporter.

This paper was written in 1978 and updated in early 1979. Since that time many states have passed statutes that address solar energy. The reader is therefore encouraged to check the most recent laws passed by the states to ensure an up-to-date knowledge of state solar legislation.

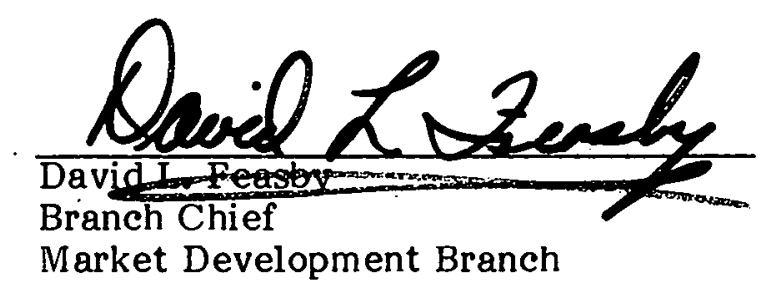

Approved for:

SOLAR ENERGY RESEARCH INSTITUTE

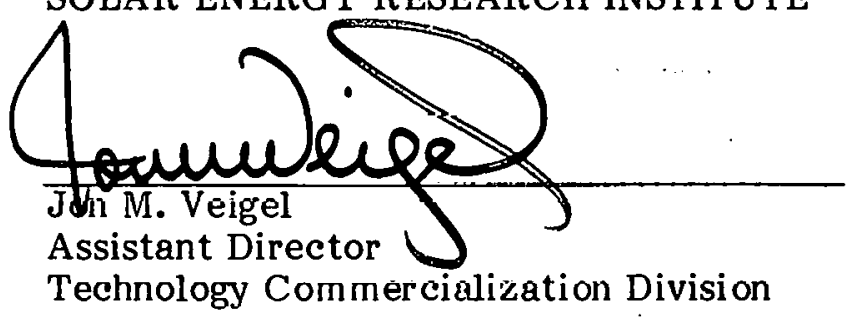


THIS PAGE

\section{WAS INTENTIONALLY \\ LEFT BLANK}




\section{SUMMARY}

As recently as 1973 , no states had enacted significant solar legislation. Since that time, the pace of consideration and passage of state statutes designed to encourage the application of solar technology has dramatically accelerated: A complex and extensive body of state solar law has now emerged, although it is still rapidly evolving. This paper is a comprehensive survey of that body of state statutes through early 1979.

Most such legislation falls into several broad categories. A large majority of the states have enacted financial incentives designed to stimulate solar energy use. Commonly, these incentives include preferential property tax treatment of solar systems, and income tax benefits to solar users. There are a wide variety of other tax breaks as well, including excise and franchise tax incentives. Some states have recently developed loan or grant programs for solar installations.

Other states have addressed aspects of real property and land-use planning law, which have served as barriers to either the installation of solar technology or access to sunlight. In addition to removing such obstacles as restrictive covenants and zoning limitations, the legislation of several states provides affirmative recognition of the potential of real property law to serve as a spur to solar development, through solar easements, planning and zoning, and public nuisance. There are a growing group of statutes governing building codes and standards for performance, testing, and materials.

A small number of states have legislated in the field of utility regulation. These statutes address important questions of nondiscriminatory rates for utility backup to solar systems and public utility commissions, and utility involvement in solar energy applications.

Appendix A provides state-by-state summaries of solar activities promoting solar energy, including $\mathrm{RD} \& \mathrm{D}$, policy and informational activities, life-cycle costing, state construction, the Solar Energy Research Institute site completion, and sponsorship of Sun Day. Appendices $\mathrm{B}$ and $\mathrm{C}$ of fer comments on finding the law relating to solar energy in any particular state, including information on major summary sources, state codes, research methodologies, and citation forms and pointers. 
THIS PAGE

\section{WAS INTENTIONALLY \\ LEFT BLANK}




\section{TABLE OF CONTENTS}

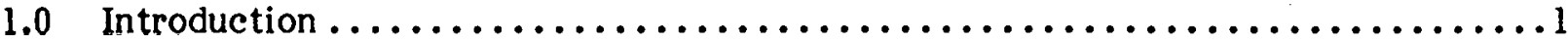

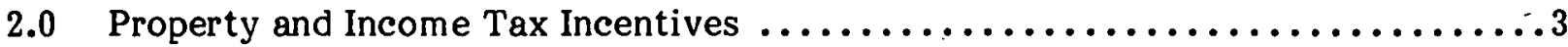

2.1 Property-Related Incentives $\ldots \ldots \ldots \ldots \ldots \ldots \ldots \ldots \ldots \ldots \ldots \ldots \ldots$

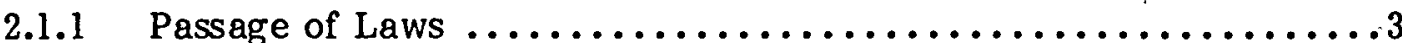

2.1.2 Eligible Technologies $\ldots \ldots \ldots \ldots \ldots \ldots \ldots \ldots \ldots \ldots \ldots \ldots \ldots \ldots \ldots$

2.1.3 Eligible Buildings..............................

2.1.4 Application Procedures and

Eligible Recipients ..........................

2.1.5 Installation Timing and

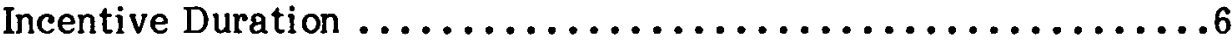

2.1.6 Exemptions Versus Credits $\ldots \ldots \ldots \ldots \ldots \ldots \ldots \ldots \ldots \ldots \ldots \ldots \ldots$

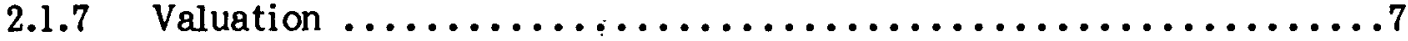

2.1.8 Measurement Formulae ...........................

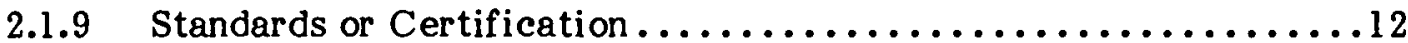

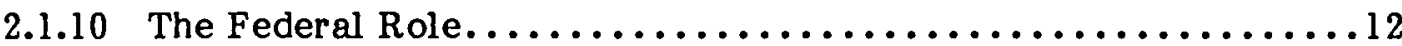

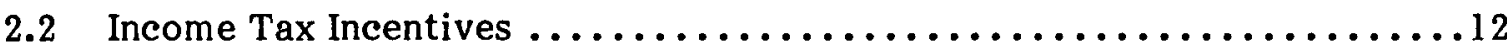

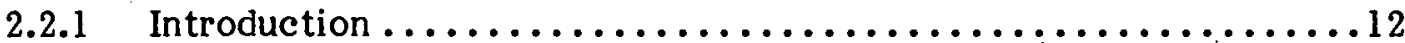

2.2.2 Eligible Structures and Taxpayers $\ldots \ldots \ldots \ldots \ldots \ldots \ldots \ldots \ldots \ldots$

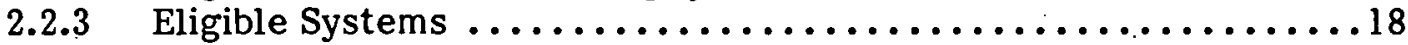

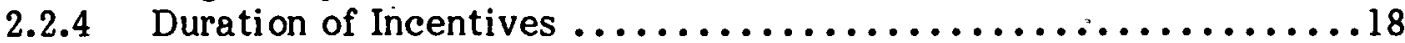

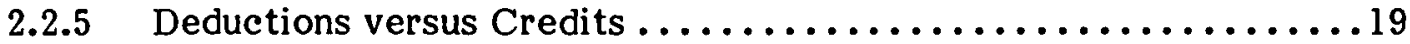

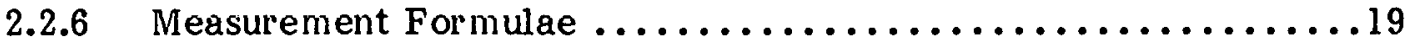

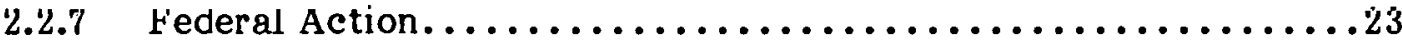

2.3. Excise Tax Incentives: Sales and Use, Transaction

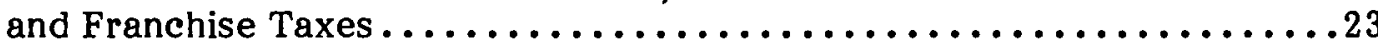

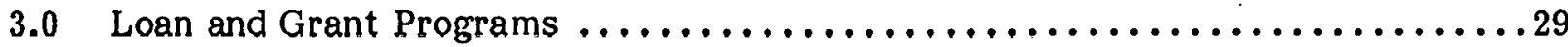

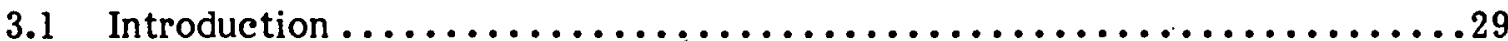

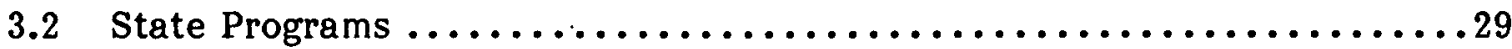

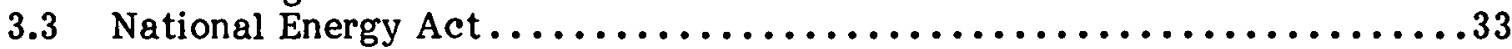

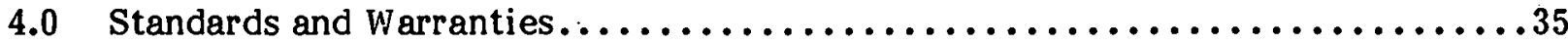

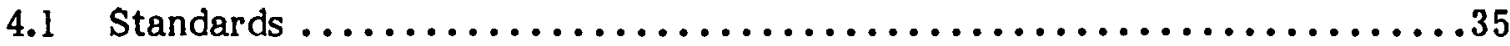

4.1.1 Policy and Authority..................................

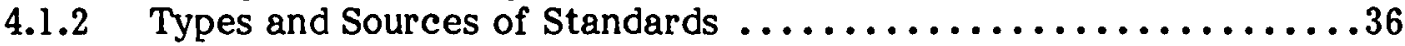

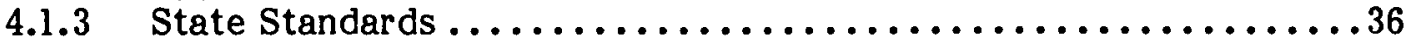


TABLE OF CONTENTS (concluded)

$\underline{\text { Page }}$

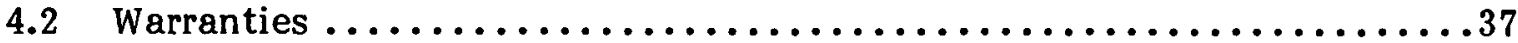

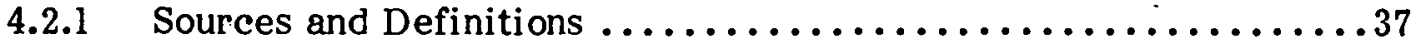

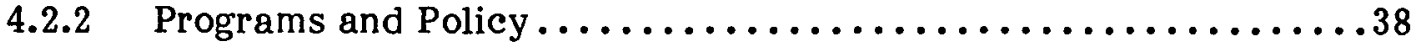

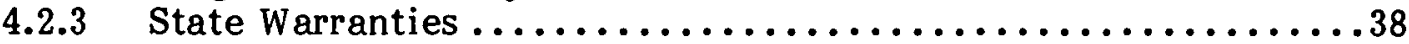

5.0 Building Codes $\ldots \ldots \ldots \ldots \ldots \ldots \ldots \ldots \ldots \ldots \ldots \ldots \ldots \ldots \ldots \ldots \ldots \ldots \ldots \ldots \ldots$

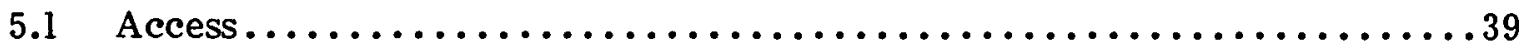

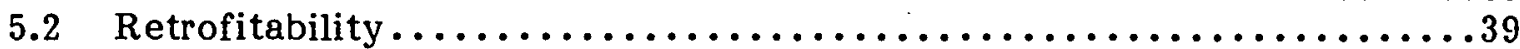

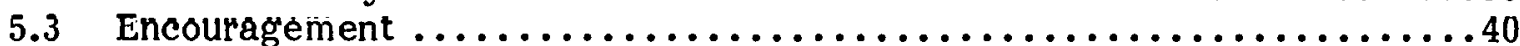

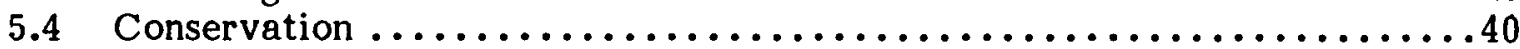

6.0. Access to Sunlight...................................

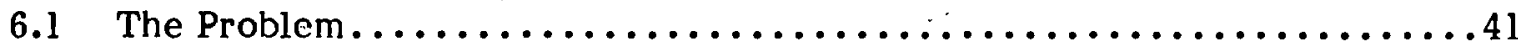

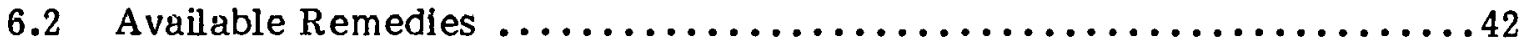

6.3 The Legislative Response............................

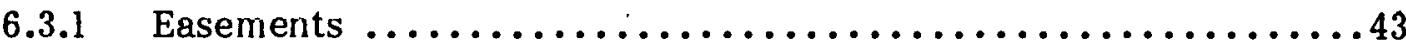

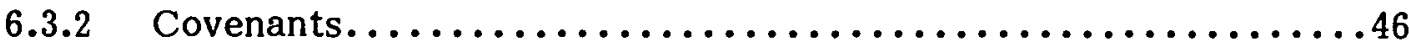

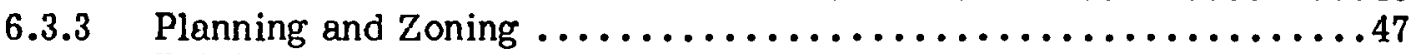

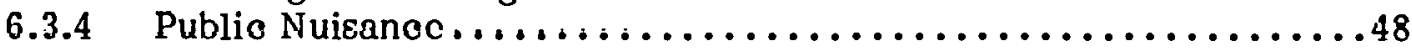

6.3.5 Solar Rights by Analogy to Water Law $\ldots \ldots \ldots \ldots \ldots \ldots \ldots \ldots$

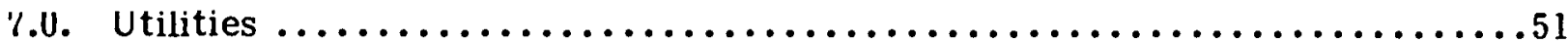

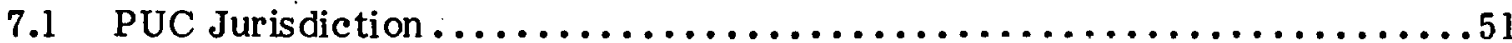

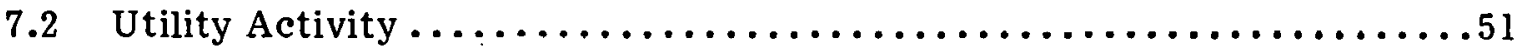

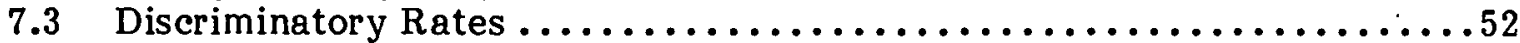

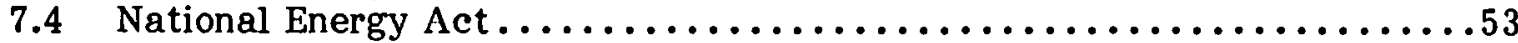

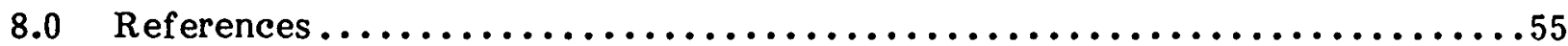

Appendix A: State Promotional Activities...................... A-1

Appendix B: Finding the Law..............................

Appendix C: State Codification and Legislation

Citations .................................. C-1 


\section{LIST OF TABLES}

\section{$\underline{\text { Page }}$}

Table

2-1 Real Property Tax Incentives $1 / 79 \ldots \ldots \ldots \ldots \ldots \ldots \ldots \ldots \ldots \ldots \ldots \ldots \ldots \ldots$

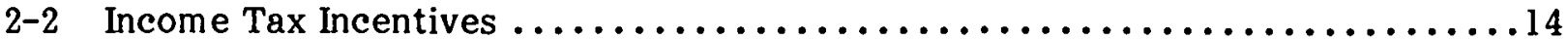

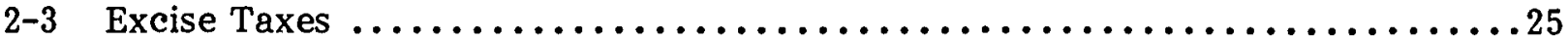

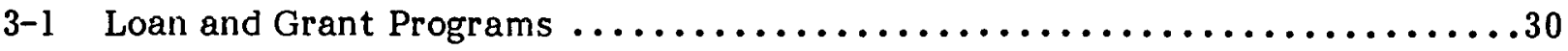




\section{SECTION 1.0}

\section{INTRODUCTION}

The constitutional framework of the United States is largely based on state government, the source and final repository of all political power not otherwise delegated to the Federal Government or reserved to the people [1]. This system of federalism is responsible for the popular conception of the states as "laboratories of democracy." Except for federal efforts in solar research, demonstration [2], and standards [3], virtually all of the pre-1979 incentives for the commercialization and exploitation of solar energy have originated with state and local government. This phenomenon is most appropriate considering the popular appeal of solar energy [4], the distinctly local and decentralizing impact of most available solar technologies, climatic variations, and even the diffuse nature of sunlight. While the preeminent role of the states may decline-especially in the case of financial incentives, due to the recent passage of laws collectively referred to as the National Energy Act [5]-the states and their citizens remain the leaders in encouraging solar energy development.

The following description and comparison of the legislative efforts of the states in the areas of property, income, excise; and franchise taxation; loans; standards and warranties; building codes; solar access; utilities; and promotional activities is conceptually oriented, and systematically assesses the laws that define some of the parameters of the solar experiments in the states. Administration of solar legislation is, with minor exceptions, not discussed [6]. 


\section{SझP|}




\section{SECTION 2.0}

\section{PROPERTY AND INCOME TAX INCENTIVES}

Financial incentives offer the quickest and the most effective means by which to encourage solar commercialization. Solar technologies are disadvantaged when they must compete economically with conventional energy sources such as coal, oil, or natural gas. In addition to price controls, these energy sources have received federal subsidies since 1947 of over $\$ 217.42$ billion [7], and are thus artificially cheap.

The existence of such subsidies alone can be used to justify solar subsidies at any governmental level. Even if one believes that the subsidies to conventional energy sources should instead be reduced in order to enhance competition in the market, powerful policy arguments remain for assisting an infant solar industry. To the extent that solar energy can reduce reliance upon dirty, expensive, capital-intensive, inefficient, or imported conventional sources of energy, beneficial effects may be expected with regard to national security, balance of payments, value of the dollar, capital availability, employment, and the environment. The ecological principle that species diversity enhances systemic stability is quite applicable to societal energy needs as well: multiple independent sources of common solar thermal technologies are virtually immune, given ample storage capacity, to breakdowns that increasingly plague integrated electrical grid systems.

Since the oil embargo of 1973-74, large numbers of state legislatures have asserted a public interest in the use of their revenue and police powers to encourage the employment of solar energy. This encouragement has most of ten taken the form of financial incentives or subsidies. The mechanisms include property tax exemptions or reduced assessments; income tax credits and deductions; rapid depreciation or amortization; franchise, sales, and use (excise) tax deductions; and low-interest or guaranteed loans. States vary considerably in providing incentives. Some states offer only one incentive; others a synergistic combination of several. Of course, there is also variation among states in the administration of the individual incentives.

\subsection{PROPERTY-RELATED INCENTIVES}

\subsubsection{Passage of Laws}

Solar property tax exemptions are the most popular financial incentive device. Twentyeight states are currently offering real property tax exemptions for solar energy systems. Florida and Texas voters approved constitutional amendment referenda allowing property tax exemptions in the November 1978 elections [8].

The necessity for such amendments in some states results from constitutional provisions that all occupation or real property taxes shall be levied or assessed in an "equal and unif orm" manner, with certain charitable exceptions [9]. Georgia ratified such an amendment in 1976 [10], allowing local adoption of the exemption. California voters rejected a proposed exemption in June 1978 [11], paralleling the Proposition 13 property tax revolt. Nebraska voters rejected a similar proposal in November 1978 [12]. 
Most states, however, are able to legislate exemptions to property taxes. This can be done under constitutional authorization, or by legislative definition of solar systems as personal property or as a separate classification of property, as Louisiana has done [13]. Perhaps the failure of more state legislatures to pass property tax exemptions reflects a hesitancy to disturb local revenues. Montana has replaced its property incentives with income tax credits [14], but not all states have income taxes.

All property tax exemptions can be portrayed as somewhat destructive of local governmental revenues, as well as discriminatory, as opposed to equal and uniform in effect. The New York legislature dealt with the local revenue objection by finding that a legislative exemption would not reduce "tax income to the community" [15]. Obviously as solar use increases, the increase in growth of local revenues may be slowed, but this is not the only impact to be considered. It has been pointed out that solar installation could reduce a community's overall expenditures by lessening net pollution, reducing fossil fuel expenditures, and encouraging more energy-efflclent zoning [16]. The discriminution concern may be obviated by the necessity to make classifications among different types of property, when constitutional barriers are faced.

\subsection{2 Ëligible Technologies}

In the case of property tax exemptions, the threshold issue is the proper choice and definition of eligible solar technology. This issue has two components. First, there must be a determination as to whether the solar system is "real property" subject to taxation. Second, the legislature must choose which technologies should be eligible.

Most common solar heating and cooling devices become permanent fixtures. As such, they are considered real property subject to property taxation when they are attached to a building, if their removal would damage the building's structure. Devices incorporated in the design or construction are also taxable realty by definition. Side-yard collectors and mobile solar devices are classified as tangible personal property, and their taxable status varies among the states. If permanently attached, although removable, they may in some cases be considered a real property improvement.

All state statutes include solar heating and cooling of buildings (SHACOB) equipment in their definitions of solar energy system or device, alternative energy device, or renewable energy resource, at least where heating and cooling is accomplished by means of flat-plate collector systems. Normally the entire "active" system (pipes, pumps, storage tanks, wiring, etc.) is included in the SHACOB exemption, while elements of a supplementary or conventional backup system are excluded. Only New Hampshire has limited its exemption for solar energy systems to collectors [17]. On the other hand, far fewer state statutes recognize the relatively exotic solar technologies such as windmills, biomass conversion, photovoltaics, thermal-electric, low-head hydroelectric, and water temperature gradient (see Table 2-1).

In addition to active $\mathrm{SHACOB}$ systems, many states have provided exemptions for the next most common solar technologies -- passive (structural) heating and cooling design and domestic water heaters [18]. The passive issue is particularly sensitive, for some of the techniques employed in passive design (i.e., high-mass walls, moveable walls, ventilation eaves, bead walls, moveable ceilings, earth berms, and film windows) incorporate structures or modifications of structures that are present in most houses. Passive design to promote energy conservation is most useful in planning a new house because it can substantially reduce the energy investment or backup heating and cooling equipment 
required. Passive design creates the problem of differentiating for tax incentive purposes between the uniquely solar characteristics, and those which are ordinarily present in an unmodified structure or in one not designed to capture and conserve solar energy.

Many states have restricted their definitions of eligible solar energy systems to those using incident sunlight "directly and exclusively" for solar heating and cooling. North Carolina explicitly excludes passive solar designs [19]. On the other hand, several states explicitly recognize and allow passive systems [20]. New Jersey includes passive solar design [21] in its definition as evaporative cooling, or nocturnal heat radiation, typically deriving from large thermal masses like those found in Harold Hay's roof pond or the Trombé wall [22]. States that might implicitly exclude passive design could do so through a requirement that the solar system "collect, transfer, and store" incident solar radiation through the use of solar "equipment." In general, only active solar heating systems mechanically transfer energy between collection and storage. Other indications of exclusion of passive systems are requirements of separate storage, or specific reference to equipment or devices that exclude purely passive structural building components.

Express inclusion of specific solar technologies in incentive statutes is recommended where there is a desire not to exclude such devices. This is especially important for technologies with immediate commercial viability, like water heaters. In those states which define solar equipment in accordance with federal performance standards, hot water systems are automatically eligible because they are included in the federal definition of "solar heating" or "solar heating and cooling" [23]. Some conventional heating systems heat both space and water at a single point, further confusing the issue. A possible reason for the paucity of explicit incentives for hot water heaters is that such systems are already economically viable in most parts of the country, based on life cycle costs. However, omission of water heating systems from incentive programs may also be due to ambiguous statutory definitions of eligible technology. Occasionally there is criticism of use of the term "hot water heater." While this term may seem redundant, solar water heaters are commonly backed up by conventional water heaters, which use them as storage tanks; literally speaking they are "hot" water heaters.

\subsubsection{Eligible Buildings}

With the exception of Nevada [24] and Louisiana [25], all state property tax incentives apply to commercial as well as residential buildings or structures. The term "commercial" includes industrial and, occasionally, agricultural structures. Georgia is alone in exempting equipment used directly in the manufacture of solar devices [26], a real boost to the numerous small businesses that compose much of the solar industry. By contrast, Michigan disallows an exemption for the property of corporations involved in the design or building of solar devices for resale [27]. Indiana has amended its property tax statute to exempt solar improvements on mobile homes [28]. However, statutory definitions of real property or administrative regulations could achieve the same result in some states [29].

\subsubsection{Application Procedures and Eligible Recipients}

In states that automatically exempt solarized structures from increased property taxes, anyone paying the tax bill could conceivably benefit, including lessees, tenants, or other occupants, as well as the owners. Other states require an application for exemption by 
the owner, on either an annual or permanent basis. South Dakota eliminates the exemption if title is transferred, unless the transferee is the first occupant in a residential building [30], though originally the only eligible recipient was the owner who also occupied the building [31]. In that state the administration of application procedures is typically complex: the owner must send for permanent application forms from the Department of Revenue; include information as to the type of system, cost, etc.; attach receipts; and file two copies with the county auditor and one with the Department of Revenue. The county assessor then verifies the statement, whereupon the auditor makes the deduction from the tax rolls.

Many states have strict application dates or deadlines. The value of such an application process is that it can generate information on the use of the incentive, and it allows monitoring of system conformance to state regulations and standards. In states that have complex procedures to assess solar energy systems, red tape may be hard to eliminate. However, some states provide an incentive by simply not assessing the solar energy system. In these states government red tape and expenses should be lower. Often, differences in assessment procedures are caused by variations in constitutional treatment of real property [32].

\subsubsection{Installation Timing and Incentive Duration}

Almost two-thirds of the 28 states with property tax exemptions have some kind of time limitation. Limitations on time of installation may precipitate solar investments sooner than would otherwise be the case, as well as protecting the state revenue from "suffering" in the indefinite future. Connecticut, Georgia, Maine, Michigan, Minnesota, New York, North Carolina, and Washington have enacted installation date limitations. No taxpayer has a guarantee of future availability of an incentive, since states or localities can always repeal exemptions. Built-in installation date limitations, a fixed duration of the incentive, or a date certain for its termination serve notice to potential solar purchasers that early acquisitions may be more cost-effective.

Another rationale for such time limitations, especially for the termination provisions, is that most eligible solar systems will eventually become more economically competitive with conventional energy sources as fuel prices rise due to oil price deregulation, cartel action, supply scarcity, or as mass production and technical advances lower solar system costs. When solar technologies (e.g., water heaters) demonstrate independent viability in the marketplace, the purely economic justification for the subsidy ceases. But other barriers, such as lack of public knowledge or acceptance by financial institutions, may persist several years af ter economic viability. Therefore, termination dates may reflect more than just the predicted attainment of economic viability by a solar energy system. Most termination dates range near the mid-1980s. Oregon's provision doesn't expire until 1998 [33]. Connecticut would allow the exemption for 15 years after 1991 [34], while New Hampshire offers a permanent exemption [35].

Limitations on duration range from 3 to 20 years, with 5 to 7 years being the norm. Massachussets amended its duration limit from 10 to 20 years in 1978 [36]. The most restrictive (three-year) duration period is found in Maryland [37]. South Dakota allows only three years of participation by corporations [38]. Both of these duration limits accompany credits instead of the more usual exemptions.

Three states have targeted the tax exemptions for installations made after a certain date, probably because most early purchasers who could afford solar devices were 
considered to have little need for an incentive applied retroactively to systems already in place. However, equitable considerations have prevailed in most states against such exclusions of prior installations.

\subsubsection{Exemptions Versus Credits}

As noted earlier, the usual method of structuring incentives is by an exemption from increased property tax assessment. In addition to Maryland and South Dakota, only Kansas and Nevada offer credits or refunds to property taxpayers. A 1977 Nevada statute appropriated $\$ 32,000$ for reimbursement to applicants [39]. While such a system generates increased administrative costs and delays the actual benefit, credits under any form of taxation are generally more efficacious and popular than are deductions.

\subsubsection{Valuation}

States vary in their property tax assessment procedures, relying on market data, income production, replacement-depreciation, or other indicia of property value. The procedures are not of ten apparent from the bill language; further code research for individual states is necessary to ascertain which technique is used. Most states relying on market data could simply choose to ignore the increase in value due to solar installations. In other words, a system would simply not be assessed, rather than being separately assessed and exempted. This technique is administratively simple, and is recommended in the model property tax exemption statute proposed by the authors of the American Bar Foundation study [40].

\subsubsection{Measurement Formulae}

Technically, exemptions from property value improvements are classified as part of the body of ad valorem taxation laws. Ad valorem taxes charge a fixed proportion of the value of the property [41]. The exemption is a privilege granted to a taxpayer/debtor on grounds of public policy, allowing retention of property or earnings [42].

The most common exemption (found in sixteen states) is for the entire cost, assessed value, or price of the solar system, depending upon the valuation procedure in the particular state. This measurement (see formula 2, Table 2-1) is of ten computed as the assessed value of the property with a solar energy system, minus the assessed value without the system. This is the most generous formula, assuming that the system works well enough so as not to decrease the market value of the property. Theoretically, the exemption could be largest for new homes using eligible passive systems, as opposed to retrofits of active systems onto homes with usable conventional heating and cooling systems. This is becuuse without the passive system, which also reduces the heating requirements of a home, large heating costs at low levels of efficiency would become nccessary, thereby reducing present marketability.

Most amendments to property and income exemptions broaden, rather than restrict, the size of the incentive. New York recently amended its formula to exempt the entire assessed value of the solar system [43], instead of subtracting the assessed value of a typical conventional system from the increased valuation due to the solar system (see formulas 1 and 2, Table 2-1). 
Table 2-1. REAL PROPERTY TAX INCENTIVES 1/79

\begin{tabular}{|c|c|c|c|c|c|c|}
\hline State & Ariz. & Colo. & Conn. & Fla. & Ga. & Hawaii \\
\hline Year(s) & 74 & 75 & 76,77 & 78 & 76 & 76 \\
\hline Law-Chapter No. & 165 & 344 & 409,490 & 354 & SR. 284 & 189 \\
\hline Const. Amend. & & & & 9 & 9 & \\
\hline Local Adoption & & & $\bullet$ & & & \\
\hline $\begin{array}{l}\text { Legal Codification } \\
\text { (Primary) }\end{array}$ & $\begin{array}{c}\text { ARS } \\
42-123.01\end{array}$ & $\begin{array}{c}\text { CRS } \\
39-1-104 \\
39-5-105 \\
\end{array}$ & \begin{tabular}{|c|}
$\mathrm{CSA}$ \\
$12-81(56)$ \\
\end{tabular} & $\begin{array}{c}\text { FSA } \\
193.622\end{array}$ & $\begin{array}{l}\text { GCA } \\
2-4604\end{array}$ & $\begin{array}{c}\text { HRS } \\
246-34.7\end{array}$ \\
\hline $\begin{array}{l}\text { System } \\
\text { SHACOB } \\
\quad \text { (Collectors Only) } \\
\text { Passive } \\
\text { Hot Water } \\
\text { Wind } \\
\text { Bio } \\
\text { PV } \\
\text { Hyd?n/Tr } \\
\end{array}$ & $\begin{array}{l}\bullet \\
\bullet \\
\bullet \\
\bullet\end{array}$ & 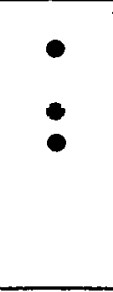 & $\begin{array}{l}\bullet \\
\bullet \\
\bullet \\
\bullet\end{array}$ & - & 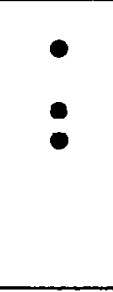 & $\begin{array}{l}\bullet \\
\bullet \\
\bullet \\
\bullet \\
\bullet \\
\bullet\end{array}$ \\
\hline $\begin{array}{l}\text { Building } \\
\text { Residential } \\
\text { Commercial } \\
\text { Other } \\
\end{array}$ & : & & ? & & : & \\
\hline $\begin{array}{l}\text { Procedure } \\
\text { Apply } \\
\text { Automitic } \\
\end{array}$ & $\bullet$ & - & $\bullet$ & & - & $\bullet$ \\
\hline $\begin{array}{r}\text { Install- } \begin{array}{l}\text { By } \\
\text { After }\end{array} \\
\end{array}$ & & & $\begin{array}{l}10 / 1 / 91 \\
10 / 1 / 77 \\
\end{array}$ & & & $\begin{array}{l}12 / 31 / 81 \\
6 / 30 / 76 \\
\end{array}$ \\
\hline $\begin{array}{l}\text { Duration or } \\
\text { Termination }\end{array}$ & $12 / 31 / 84$ & & 15 Yrs. & & 1986 & Open \\
\hline $\begin{array}{c}\text { Tax Exemption } \\
\text { (Deduction) or } \\
\text { Credit (Refund) } \\
\end{array}$ & - & $\bullet$ & - & & $\bullet$ & $\bullet$ \\
\hline $\begin{array}{l}\text { Valuation } \\
\text { Separnte } \\
\text { Non-Assessed }\end{array}$ & $\bullet$ & - & & & & \\
\hline $\begin{array}{l}\text { Measurement } \\
\text { Formula (Key) } \\
\end{array}$ & 2 & $5^{2}$ & 3 & 3 & 2 & 2 \\
\hline $\begin{array}{l}\text { Stendards or } \\
\text { Certification } \\
\end{array}$ & & & $\bullet$ & & & \\
\hline $\begin{array}{l}\text { Actual Use } \\
\text { Min. Energy Req. }\end{array}$ & & & & & & 0 \\
\hline $\begin{array}{l}\text { Federal } \\
\text { Preemption }\end{array}$ & & & & & & \\
\hline
\end{tabular}

Notes:

1 Manufacturing Equipment

$25 \%$ of Actual Value

$335 \%$ of tax refunded

$470 \%$ heating load capability for buildings or additions

5 excludes waterwheels

6 excludes corps in solar business 
Table 2-1. REAL PROPERTY TAX INCENTIVES 1/79 (continued)

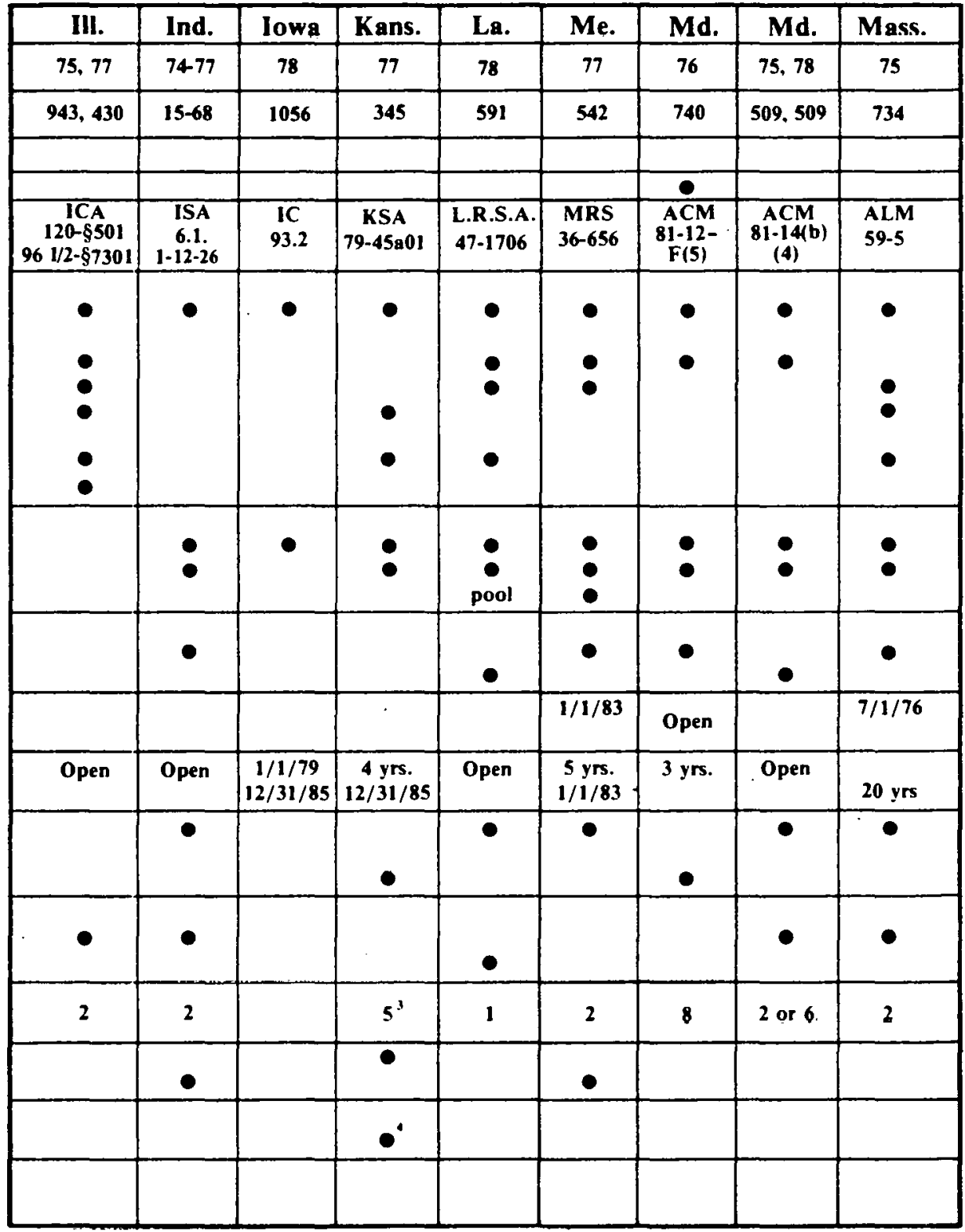

7 HUD Standards

8 Res., Comm. Then a 3 yr. declining rate $(75,50,25 \%)$ applies.

9 Res. Minimum-actual installed cost Commercial-50\% of actual installed cost

10 Excludes either whole or partial amount of assessed value, which includes installation costs.

"For supplemental (49\% max.) SES. 
Table 2-1. REAL PROPERTY TAX INCENTIVES 1/79 (continued)

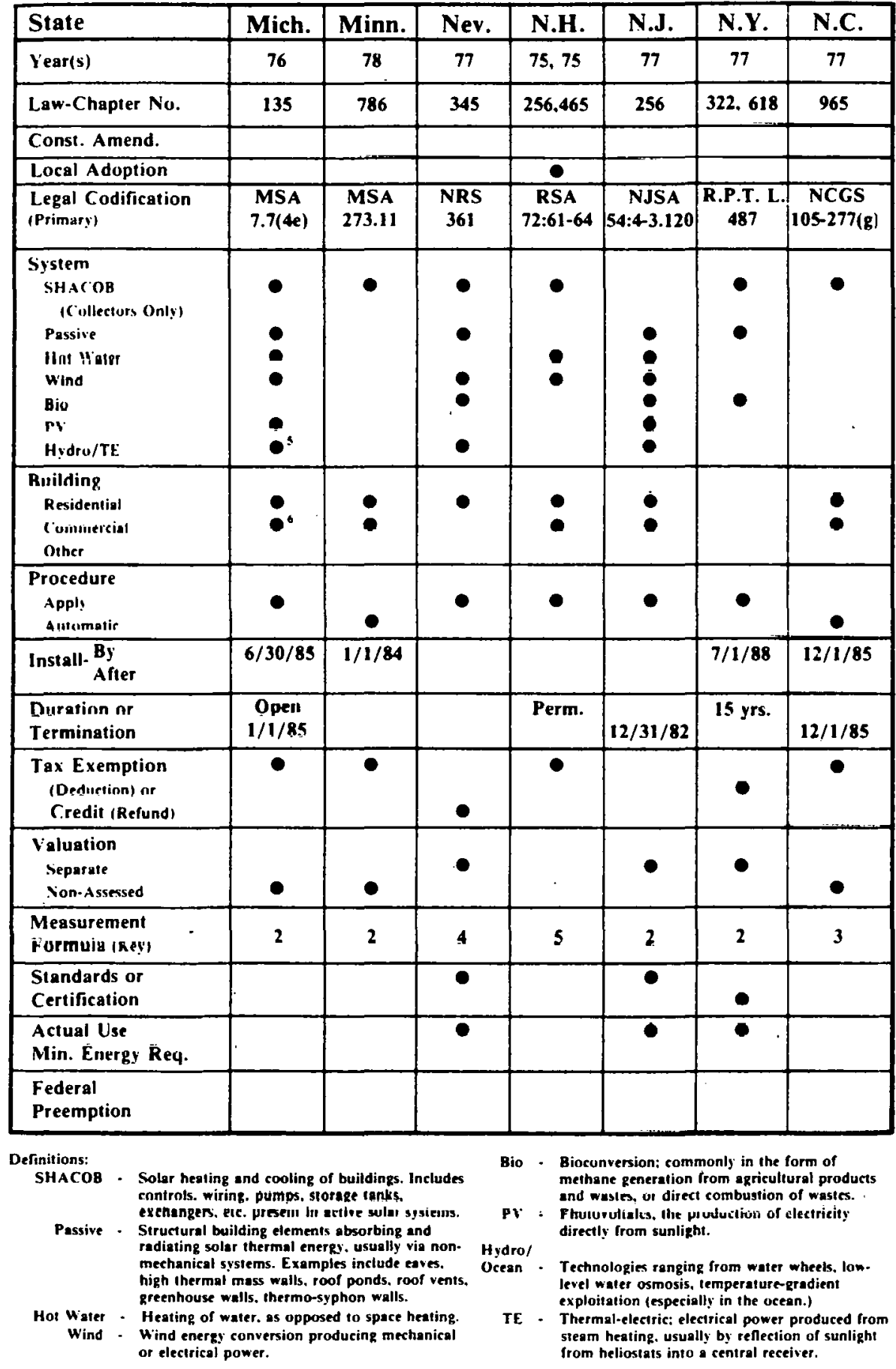


Table 2-1. REAL PROPERTY TAX INCENTIVES 1/79 (concluded)

\begin{tabular}{|c|c|c|c|c|c|c|c|c|}
\hline N.D. & Ore. & R.I. & S.D. & Tenn. & Tex. & Vt. & Vir. & Wash. \\
\hline 75 & 75.77 & 77 & 78 & 78 & 77 & 76 & 77 & 77 \\
\hline \multirow[t]{3}{*}{508} & 460,196 & 202 & 74 & 837 & SJR 53 & 226 & 561 & 364 \\
\hline & & & & & - & & & \\
\hline & & & & & & - & 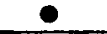 & \\
\hline $\begin{array}{r}\text { N D.C } \\
57.02-08\end{array}$ & $\begin{array}{l}\text { O.R S } \\
307.175\end{array}$ & $\begin{array}{c}R I \\
44-3-19\end{array}$ & \begin{tabular}{|c|} 
S.D.C.L. \\
$10-6-$ \\
$35.8-.18$ \\
\end{tabular} & $\begin{array}{l}\text { T.C.A. } \\
\text { 67-511 }\end{array}$ & $\begin{array}{c}\text { Tex.Con } \\
\text { art.VIII } \\
52(a) \\
\end{array}$ & $\begin{array}{l}\text { V.S.A. } \\
\text { 53-15 }\end{array}$ & $\begin{array}{c}\text { R.C. } \\
58-16.4\end{array}$ & $\begin{array}{l}\text { R.C.W.A. } \\
84.36-410\end{array}$ \\
\hline - & $\begin{array}{l}0 \\
0 \\
0 \\
0\end{array}$ & $\bullet$ & $\begin{array}{l}\bullet \\
\bullet \\
0 \\
0 \\
0 \\
0\end{array}$ & - & - & $\begin{array}{l}0 \\
0 \\
0 \\
0 \\
0\end{array}$ & $\begin{array}{l}\bullet \\
\bullet \\
\bullet \\
\bullet\end{array}$ & $\begin{array}{l}0^{\prime \prime} \\
0^{\prime}\end{array}$ \\
\hline : & • & • & - & & & ? & & • \\
\hline \multirow[t]{2}{*}{$\bullet$} & - & - & - & & & - & - & - \\
\hline & & & & & & Open & Open & $12 / 31 / 81$ \\
\hline $\begin{array}{l}5 \text { yrs. } \\
\text { Open }\end{array}$ & 1/1/98 & 4/1/97 & $\begin{array}{l}5,3^{\circ} \\
\text { yrs }\end{array}$ & $1 / 1 / 88$ & . & Open & 5 yrs. & 7 yrs. \\
\hline$\bullet$ & & $\bullet$ & & $\bullet$ & & - & $\bullet$ & $\bullet$ \\
\hline - & - & - & - & - & & - & $\bullet$ & $\bullet$ \\
\hline \multirow[t]{2}{*}{2} & 2 & 6 & $1,5^{10}$ & 2 & & 5 & $5^{\prime \prime}$ & 2 \\
\hline & $\bullet$ & $9^{8}$ & & - & & & - & $\bullet$ \\
\hline & & & & - & & & - & - \\
\hline & & & - & & & & & \\
\hline
\end{tabular}

Measurement Formulat - Exemption Equals:

1. Total cost/value/price $(C / V / P)$ (as assessed).

. Difference between $C / V / P$ of solar and conventional systems

3. Lesser of 2. and set dollar amount.

4. Set percentage of $C / V / P$.

5. Other - local variation or annually declining rate.

6. Maximum assessment equals value of conventional system necessary

to serve the building.

administrative interpretation and/or tegulations.

especially in the area of ctipible technulopies. 
Formula 2, which subtracts the value of a conventional system from total valuation, is sometimes phrased to require the assessor to value the property "as if it had a conventional system." In contrast to the exemption-from-increased-valuation formula (see formula 1, Table 2-1) considered previously, this could discriminate against new homes using passive systems that have only supplementary conventional heating and cooling systems, in favor of retrofit of older properties with full-size conventional backup systems. Only three states now use this formula. A variation of this formula used by Rhode Island [44] provides for a maximum assessment equal to the value of a conventional system necessary to serve the building (see formula 6 , Table 2-1). In contrast to formula 2, formula 6 favors new buildings using passive design.

Another formula (see formula 4, Table 2-1) that is used occasionally exempts a set percentage of the value of the system. Colorado was the first state to use this formula, requiring valuation at no more than $5 \%$ of actual value [45]. Kansas allows a $35 \%$ credit for five years [46].

A major formula variation is the annual declining rate (see formula 5, Table 2-1). South Dakota allows a complete exemption for residential buildings for five years, then applies a three-year schedule decreasing the exemption to $75 \%, 50 \%$, and $25 \%$ of the base credit [47]. For commercial property the declining schedule applies after only three years. Declining rates are frequently used in income tax incentives. They are premised on anticipated future increases in the prices of other competing fuel sources, which act to progressively lessen the economic need for solar subsidies.

\subsubsection{Standards or Certification}

Certification of eligible systems is a common provision designed to assure that exemptions are nonfraudulent, and/or to ensure that the system will perform well enough to justify the subsidy. In the latter case, certification is dependent upon material or performance standards. The standards are usually promulgated by state revenue agencies with assistance from state energy offices. At least two states have legislatively adopted the HUD reference standards (see Table 2-1).

\subsubsection{The Federal Role}

South Dakota [48] has determined that federal energy income tax incentives [49] will reduce the need for state-level property tax incentives. Some other states are expected to reduce this type of subsidy as federal assistance becomes publicized and is perceived to displace state or local property tax relief by making total governmental support appear overly generous.

\subsection{INCOME TAX INCENTIVES}

\subsubsection{Introduction}

Instead of merely removing potential costs barriers, as in the case of property tax incentives, income tax measures are positive inducements to "go solar" that also redistribute income in the process. This factor, combined with the limited number of states with income taxes, may account for the lesser number of income tax as opposed to property 
tax incentives. There are presently 22 separate solar income tax laws passed in a total of 16 states. (see Table 2-2).

\subsubsection{Eligible Structures and Taxpayers}

With the exception of express solar equipment depreciation and amortization deductions [50] that apply exclusively to corporations (in Massachussetts, Arizona, and Kansas), virtually all of the income tax incentive laws seem to be targeted primarily at occupants of residential structures or individual homeowners. Many of the states (Alaska, Arizona, Idaho, Montana, Oklahoma, and Oregon) offering income tax incentives restrict the availability of straight credits or deductions to residential dwellings, excluding industrial or commercial buildings. While this dichotomy can be justified for populist or budgetary reasons, or out of sympathy for the residential energy consumer faced with expensive fossil fuels and limited income, some doubt exists as to the efficacy of exclusively noncommercial incentives in causing substantial change in building design. A 1974 study found that successful innovations in building design have always been introduced first in public and commercial buildings and then in custom houses, befure tlie mass residential housing market is affected [51]. Only a small fraction of housing is custom-built. States considering solar/income legislation might attempt to take advantage of this "trickledown" demonstration effect, and allow commercial as well as residential deductions or credits.

In addition to residential and commercial buildings, several states have provided deductions or credits for other types of structures and uses of solar energy. An Arkansas law broadly refers to "any structure using solar heating" [52]. California explicitly recognizes condominium owners as eligible on a pro-rated basis [53]. New Mexico includes solar-powered irrigation systems, while California includes solar-heated pools [54]. North Carolina has recognized individually metered family units in multi-dwelling buildings as eligible, if the installer owns or controls the unit and has paid the majority of the proportional cost [55]. Most states limit residential eligibility to principal dwellings, occasionally specifying that the dwelling situs be in the state.

The eligible taxpayer is usually a resident individual. Often the taxpayer must stand in a certain legal or financial relationship to the property, such as being an owner or contracl purchaser. Residency must generally coincide with completed installation of a solar system for most deductions, especially in the case of deductions for primary dwellings.

Oregon is unique in explicitly providing incentives for both nonresidents and secondary dwellings [56]. However, the lawws of several other slules cuuld be inter:preted to include secondary dwellings, where no limitation to principal dwellings is specified, and where taxpayers are not expressly limited to one exemption per year. Alaska has joined Oregon in allowing for credits by nonresident taxpayers [57]. About one-half of such states have made provisions for the claiming of deductions when the property is held jointly or communally, and when taxes are filed separately. Usually the deduction or credit can be claimed in whole, or proportionately by any co-owner. New Mexico is an exception to this rule [58].

Even in jurisdictions allowing multi-year income tax incentives, few states have explicitly considered continuing incentives for subsequent purchasers or transferees. Perhaps the reason is that once the initial installation is made, the main purpose of the incentive has been achieved. Most states still require installation by the taxpayer as a precondition to a claim, thereby excluding transferee eligibility. However, California has rejected its earlier original use requirement [59]. 
Table 2-2. INCOME TAX INCENTTVES

\begin{tabular}{|c|c|c|c|}
\hline State & Alas. & Ariz. & Ariz. \\
\hline Year(s) & 77 & 75.76 .78 & 77.78 \\
\hline $\begin{array}{l}\text { Lawisi } \\
\text { Chapter No. }\end{array}$ & 94 & 93.129 .112 & 81.112 \\
\hline $\begin{array}{l}\text { Legal Codification } \\
\text { (Primary) }\end{array}$ & $\begin{array}{l}\text { AS } 4.3 .20 \\
0.39(d)(4)\end{array}$ & $\begin{array}{l}\text { ARS 4.3- } \\
123.37\end{array}$ & $\begin{array}{l}\text { ARS 4.3- } \\
128.03 .04\end{array}$ \\
\hline $\begin{array}{l}\text { Systen } \\
\text { SHACOB } \\
\text { Passicic } \\
\text { Hor Water } \\
\text { Wind } \\
\text { Bis } \\
\text { P' } \\
\text { Hydro TE } \\
\end{array}$ & $\begin{array}{l}\bullet \\
\bullet \\
\bullet \\
\bullet \\
\bullet\end{array}$ & $\begin{array}{l}\bullet \\
\bullet \\
: \\
: \\
\bullet \\
\bullet\end{array}$ & $\begin{array}{l}\bullet \\
: \\
\bullet \\
\bullet\end{array}$ \\
\hline Criteria/Regs & & & $\bullet$ \\
\hline $\begin{array}{l}\text { Building } \\
\text { Residential } \\
\text { Commercial } \\
\text { Other } \\
\end{array}$ & $\bullet$ & $\bullet$ & $\bullet$ \\
\hline $\begin{array}{l}\text { Duration/or } \\
\text { Termination } \\
\end{array}$ & $\begin{array}{l}12 / 31 / 76 \\
12 / 31 / 82 \\
\end{array}$ & $12 / 31 / 84$ & $\begin{array}{l}12 / 31 / 77 \\
12 / 31 / 84 \\
\end{array}$ \\
\hline $\begin{array}{l}\text { Deduction/or } \\
\text { Credit }\end{array}$ & - & $\bullet$ & $\bullet$ \\
\hline $\begin{array}{l}\text { Measurement } \\
\text { Formuia }\end{array}$ & No. 1 & $\begin{array}{l}36 \mathrm{mo} . \\
\text { amort. }\end{array}$ & No. 2 \\
\hline \multicolumn{4}{|l|}{$\begin{array}{l}\text { Actual Energ! lise } \\
\text { Min. Encrg! Rey. }\end{array}$} \\
\hline \multicolumn{4}{|l|}{ Federal Displacement } \\
\hline $\begin{array}{l}\text { Eligible Taxpayer } \\
\text { Residential Individual } \\
\text { Installer (Ouner } \\
\end{array}$ & $\bullet$ & $\bullet$ & - \\
\hline $\begin{array}{l}\text { Depreciation/ } \\
\text { Amortization } \\
\end{array}$ & & or $\bullet$ & \\
\hline In licu or & & & $\bullet$ \\
\hline Carryover. & & & 5 yrs \\
\hline $\begin{array}{l}\text { Costs } \\
\text { Installation } \\
\text { Supplemental Equip. } \\
\text { Remodellng } \\
\end{array}$ & $\bullet$ & $\bullet$ & - \\
\hline Situs In State & $\bullet$ & $\bullet$ & $\bullet$ \\
\hline $\begin{array}{l}\text { Expenditures/Instal- } \\
\text { lation/After }\end{array}$ & $12 / 31 / 76$ & & \\
\hline Apply: & & & \\
\hline
\end{tabular}

1. $10 \%$ of expenses of installation, maximum \$200. Also $5 \%$ of residential fuel costs (wood) (Alaska).

2. $35 \%$ of cost, declining $5 \%$ per year, until 1984, maximum $\$ 1000$. Also $25 \%$ of cost of insulation, winddriven turbine, ventilation, or passive roof vent, maximum $\mathbf{S 1 0 0}$ (Ariz.).

3. Deduct entire cost; exclude interest. finance charges, acquisition, installation.

(Ark.)

4. $55 \%$ of cost, maximum $\$ 3000$. In multi- 
Table 2-2. INCOME TAX INCENTTVES (continued)

\begin{tabular}{|c|c|c|c|c|c|}
\hline Ark. & Cal. & Colo. & Hawaii & Idaho & Kansas \\
\hline 77 & 76.77 .78 & 77 & 76 & 76 & 76 \\
\hline 535 & 168.1082 .1159 & 512 & 189 & 212 & 434 \\
\hline $\begin{array}{l}\text { ASA 84- } \\
2016.8-10\end{array}$ & $\begin{array}{l}\text { Rev \& Tax } \\
\$ 17052.5\end{array}$ & $\begin{array}{l}\text { CRS } 39 . \\
22-11.3(4)(C)\end{array}$ & HRS 2.35-12 & $\begin{array}{l}\text { IC } 6.3- \\
3022 \mathrm{C}\end{array}$ & $\begin{array}{l}\text { KSA 79-32. } \\
166-167\end{array}$ \\
\hline$\bullet$ & $\begin{array}{l}\bullet \\
\bullet \\
\bullet \\
\bullet\end{array}$ & $\stackrel{\bullet}{\bullet}$ & 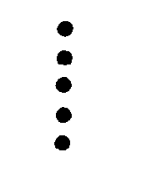 & $\begin{array}{l}\bullet \\
\bullet \\
\bullet \\
\bullet\end{array}$ & $\begin{array}{l}\bullet \\
\bullet \\
\bullet \\
\bullet\end{array}$ \\
\hline$\bullet$ & $\bullet$ & & & & $\bullet$ \\
\hline$\bullet$ & $\bullet$ & : & $\bullet$ & $\bullet$ & $\bullet$ \\
\hline $\begin{array}{l}1 / 1 / 77 \\
\text { open }\end{array}$ & $1 / 1 / 81$ & $\begin{array}{l}1 / 1 / 77 \\
\text { open }\end{array}$ & $\begin{array}{l}6 / 30 / 76 \\
12 / 31 / 81\end{array}$ & & $\begin{array}{l}12 / 31 / 75 \\
7 / 1 / 83\end{array}$ \\
\hline - & $\bullet$ & $\bullet$ & - & $\bullet$ & $\bullet$ \\
\hline \multirow[t]{3}{*}{ No. 3} & No. 4 & No. 3 & No.s & No. 6 & No. 7 \\
\hline & $\bullet$ & $\bullet$ & $\bullet$ & & $\bullet$ \\
\hline & $\bullet$ & & & & \\
\hline \multirow[t]{2}{*}{$\begin{array}{l}\bullet \\
\bullet \\
\end{array}$} & $\bullet$ & $:$ & : & $\bullet$ & 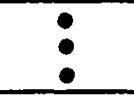 \\
\hline & $\bullet$ & $\bullet$ & $\bullet$ & & \\
\hline No & Ves & & & & 4 yrs-ind. \\
\hline$\bullet$ & $\bullet$ & $\bullet$ & & $\bullet$ & • \\
\hline \multirow[t]{2}{*}{$\bullet$} & - & & & & \\
\hline & & $1 / 1 / 77$ & $12 / 31 / 74$ & & \\
\hline & & & & & \\
\hline
\end{tabular}

dwelling houses or commercial buildings where cost exceeds $\$ 12,000,25 \%$ of the cost. Federal credits claimed shall reduce California credits to equal total credit of 55\%. Grants are excluded from cost basis.
5. $10 \%$ of total cost of device.

6. $40 \%$ of cost for year of purchase, $20 \%$ for 3 years thereafter, maximum $\$ 5000$ for any one year (entire cost over 4 years).

7. $25 \%$ of cost, maximum $\$ 1000$ for individuals. Maximum $\$ 1000$ per 
Table 2-2. INCOME TAX INCENTTVES (continued)

\begin{tabular}{|c|c|c|c|c|c|}
\hline & State & Kansas & Mass. & Mont. & Mont. \\
\hline & Year(s) & 77.78 & 76 & 77 & 77 \\
\hline & $\begin{array}{l}\text { Law(s) } \\
\text { Chapter No. }\end{array}$ & 346.409 & 487 & 574 & 576 \\
\hline & $\begin{array}{l}\text { Legal Codification } \\
\text { (Primary) }\end{array}$ & $\begin{array}{l}\text { KSA 79-32. } \\
\text { 168: 79-1118 } \\
\end{array}$ & $\begin{array}{l}\text { AL.M c63 } \\
\$ 38 \mathrm{H} \\
\end{array}$ & $\begin{array}{l}\text { RMC } 87 \\
7414 \\
\end{array}$ & $\begin{array}{l}\text { RMC 84- } \\
7403 \\
\end{array}$ \\
\hline & $\begin{array}{l}\text { System } \\
\text { SHACOB } \\
\text { Passive } \\
\text { Hot Water } \\
\text { Wind } \\
\text { Bio } \\
\text { PV } \\
\text { Hydro TE } \\
\end{array}$ & $\begin{array}{l}\bullet \\
\bullet \\
\bullet \\
\bullet\end{array}$ & $\bullet$ & $\begin{array}{l}\bullet \\
\bullet \\
\bullet \\
\bullet \\
\bullet \\
\bullet\end{array}$ & $\begin{array}{l}\bullet \\
\bullet \\
\bullet \\
\bullet \\
\bullet\end{array}$ \\
\hline & Criteria/Regs & $\bullet$ & - cert. & $\bullet$ & $\bullet$ \\
\hline & $\begin{array}{l}\text { Ruilding } \\
\text { Residential } \\
\text { Commercial } \\
\text { Other } \\
\end{array}$ & $\bullet$ & $\bullet$ & - & $\bullet$ \\
\hline & $\begin{array}{l}\text { Duration/or } \\
\text { Termingtion }\end{array}$ & $\begin{array}{l}12 / 31 / 75 \\
7 / 1 / 83\end{array}$ & & $\begin{array}{l}12 / 31 / 76 \\
12 / 31 / 82 \\
\end{array}$ & $\begin{array}{l}12 / 31 / 96 \\
\text { open }\end{array}$ \\
\hline & $\begin{array}{l}\text { neduction/or } \\
\text { Credit }\end{array}$ & $\bullet$ & $\bullet$ & $\bullet$ & $\stackrel{\bullet}{\bullet}$ \\
\hline & $\begin{array}{l}\text { Measurement } \\
\text { Formula } \\
\end{array}$ & No.T & No. 3 & No. 8 & No. 9 \\
\hline & $\begin{array}{l}\text { Actual Energy Use } \\
\text { Min. Energy Req. }\end{array}$ & $\bullet$ & & & \\
\hline & Feoefal Ulspiatenuent & & & $\bullet$ & \\
\hline & $\begin{array}{l}\text { Eligible Iaxpayer } \\
\text { Residential individual } \\
\text { Installer Ow'ner } \\
\end{array}$ & 0 & $\div$ & $:$ & $\because$ \\
\hline & $\begin{array}{l}\text { Uepreciation/ } \\
\text { Amortization } \\
\end{array}$ & $\begin{array}{r}60 \mathrm{mo} . \\
-\quad \text { amort. } \\
\end{array}$ & $:$ & & \\
\hline & In 1.ipen nr & No & - & & \\
\hline & Carryover & No & & $4 \mathrm{yrs}$ & \\
\hline & $\begin{array}{l}\text { Costs } \\
\text { Installation } \\
\text { Supplemental Equip. } \\
\text { Remndeling } \\
\end{array}$ & $\bullet$ & $\bullet$ & $\bullet$ & $\cdot \bullet$ \\
\hline & Situs In State & & $\bullet$ & & \\
\hline & $\begin{array}{l}\text { Expenaiture/lusial } \\
\text { lation/After }\end{array}$ & & & & \\
\hline & Apply & & & ?: & $\bullet$ \\
\hline 8. & \multicolumn{2}{|c|}{$\begin{array}{l}\text { building or metered residence in N.C. } \\
\text { Maximum of } \$ 2000 \text { for Oregon. } \$ 3000 \\
\text { for businesses in Kansas. } \\
10 \% \text { of first } \$ 1000 ; 5 \% \text { of next } \$ 3000 \text { of } \\
\text { cost, less grants received. Similar federal } \\
\text { credits result in halving Montana's } \\
\text { contributions, whether or not the credits } \\
\text { are claimed. } \\
100 \% \text { of first } \$ 1000 \text { (res)or } \$ 2000 \text { (comm) } \\
\text { expended }\end{array}$} & \multicolumn{3}{|c|}{$\begin{array}{l}50 \% \text { of next } \$ 1000 \text { (res)or } \$ 2000(\mathrm{comm}) \\
\text { expended } \\
20 \% \text { of next } \$ 1000 \text { (res) or } \$ 2000 \text { (comm) } \\
\text { expended } \\
10 \% \text { of next } \$ 1000 \text { (res) or } \$ 2000 \text { (comm) } \\
\text { expended } \\
\text { Expenditures shall not include offsetting } \\
\text { grants. } \\
\text { Maximum } \$ 1800 \text { (res) or } \$ 3600 \text { (comm). } \\
5 \% \text { of cost per year for } 2 \text { years. }\end{array}$} \\
\hline
\end{tabular}


Table 2-2. INCOME TAX INCENTIVES (concluded)

\begin{tabular}{|c|c|c|c|c|c|}
\hline N.M. & N.C. & N.D. & Ok. & Ore. & Wisc. \\
\hline 75.77 & 77 & 77 & 77 & 77 & 77 \\
\hline $\begin{array}{l}12.170 \\
114\end{array}$ & 792 & 537 & 209 & 196 & .313 \\
\hline $\begin{array}{l}\text { NMSA } 72 . \\
15 A-11.3-11.4\end{array}$ & $\begin{array}{l}\text { NCGS } \leqslant \text { 10S } \\
-151.2, \cdot 130.23\end{array}$ & $\begin{array}{l}\text { NDCC 57- } \\
38-01.8\end{array}$ & $\begin{array}{l}68 \text { OS } \\
I \$ \$ 2.357 .1-.3\end{array}$ & $\begin{array}{l}\text { ORC } \$ \$ 469.010 \\
-.140 .316-116\end{array}$ & $\begin{array}{l}\text { W.S.A. } \$ 71.04 \\
(1621.71 .09(12)\end{array}$ \\
\hline 0 & - & - & - & ? & $\dot{0}$ \\
\hline HL:DO cert. & OHID & & - & ('ert. & \\
\hline $\begin{array}{l}\text { irrig. } \\
\text { pool }\end{array}$ & 9 & 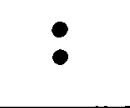 & $\bullet$ & $\bullet$ & $\begin{array}{l}\text { Credit } \\
\text { Depi. }\end{array}$ \\
\hline $\begin{array}{l}\text { open } \\
\text { pool } 1 / 1 / 78\end{array}$ & $\begin{array}{l}1 / 1 / 7710 \\
\text { open }\end{array}$ & open & $12 / .31 / 77$ & $\begin{array}{l}1 / 1 / 78 \\
1 / 1 / 85\end{array}$ & $12 / 31 / 84$ \\
\hline$\bullet$ & $\bullet$ & $\bullet$ & $\bullet$ & - & $\begin{array}{ll}\text { (Res.) } \\
\text { (Comm.) }\end{array}$ \\
\hline \multirow[t]{2}{*}{$\begin{array}{l}\text { pool max. S25K } \\
\text { No. } 7\end{array}$} & No. 7 & No. 10 & No. 11 & No. 7 & No. 12 \\
\hline & & & - & - 10\% & \\
\hline \multicolumn{6}{|l|}{ - } \\
\hline : & - & 0 & $\dot{0}$ & 9 & \\
\hline & & & & & $\begin{array}{l}5 \mathrm{yr} . \\
\text { or }\end{array}$ \\
\hline \multirow[t]{2}{*}{ Refund } & $3 \mathrm{yrs}$ & & 5 yrs & 5 yrs & Refund \\
\hline & - & Ni & - & 0 & 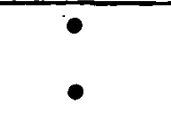 \\
\hline \multirow[t]{3}{*}{$\bullet$} & - & & & & 0 \\
\hline & & & & & $+120 / 77$ \\
\hline & & & & - & $\bullet$ \\
\hline
\end{tabular}

11. $25 \%$ of cost, maximum $\$ 2000$ per individual.

12. The following percentage of total costs (if they exceed $\$ 500$ ) for a minimum credit of $\$ 10.000$ for structures appearing on the tax roll: prior to $-4 / 20 / 77$ - after 77 and 78

79 and 80

$30 \%$

81 and 82

$20 \%$

83 and 84

$24 \%$

$18 \%$

$16 \%$

$12 \%$

Note: The author's statuatory interpretation may not always be consistent with administrative interpretutions and/or regulations, especially in the areas of eligible technologies. 
One side effect of a provision favoring transferees might be to raise the market value of the affected property, which could be marginally counter-productive as an incentive unless a solar property tax exemption also exists. Only eight states (Arizona, Colorado, Hawaii, Kansas, Massachussetts, North Carolina, North Dakota, and Oregon) currently offer both income and property tax measures. However, a policy allowing transferees to take advantage of income tax incentives offered in conjunction with property incentives could prove beneficial, since an owner who was considering moving might be more likely to invest in a solar system if the tax benefits were marketable.

Statutory provisions accompanying the incentive can deter the initial installation in cases where the recipient must be the installer, or where the installer is a developer but is unable to claim multiple credits. California allows a builder of unsold housing either to take the credit or to pass it through to the purchaser [60]. Assistance for housing built by developers promises to be of enormous benefit to solar commercialization, and deserves far greater consideration than that evidenced to date. Presently, eligibllity provisions like Oregon's, limiting a taxpayer to a single credit, could deter developers from installing solar systems in large-scale projects.

\subsubsection{Eligible Systems}

Of the various solar technologies eligible for income tax credits or deductions, solar heating and cooling of buildings (SHACOB) and water heating predominate. The two types of systems are either explicitly listed or implied in the various definitions of solar energy systems, alternative energy devices, and solar equipment. SHACOB and solar hot water have achieved greater market penetration to date than the other lesser known solar technologies. The subsidies for solar hot water should be particularly effective because the cost of an average system for a one to two family building $(\$ 1,000-\$ 2,000)$ is low enough, so that even a small price offset may provide the marginal stimulation necessary to instigate consumer purchases [61].

Wind energy conversion systems are potentially eligible for income tax incentives in eleven states. Bioconversion is generally included by the northern and western states (including Alaska, Arizona, Hawall, Idalio, Montana, North Dakota, Oregon, and Wisconsin) where appropriate agricultural applications and organic materials or wastes are readily available. Idaho provides deductions for the costs of heat pumps and burning of wood or wood products, as well as fireplaces with built-in metal heat exchangers. Hydropower, as an indirect form of solar energy, is allowed for by Alaska (tidal), Montana ("low-head" or small-dam hydroelectrlclty), and Oregon (sea-thermal gradient) (see Table 2-2).

\subsubsection{Duration of Incentives}

About one-half of the states with income tax incentives limit the duration of availability of the income tax incentive by including termination dates. These dates generally apply to the existence of the incentive, and not to installation or application timing. On the average, these states have chosen a termination date of 1983. California's program has the shortest statutory existence, and expires on 1 Jan 81 [62]. Oklahoma has the longest program, which lasts until 31 Dec 87 [63]. Although termination dates can be criticized because they require further legislation to continue the incentive, they do serve notice to potential solar purchasers to act quickly or risk losing the incentive, perhaps stimulating consumer demand faster than under an open-ended program. Another function of built-in 
expiration dates, analogous to sunset laws, is to force a review of the economic rationale for the existence of the subsidy. Proponents of continuation must then justify the program in order to continue the status quo.

States offering closed and open schedules might consider statutory provisions for monitoring and reporting of the utilization and efficacy of the incentives, including numbers and amounts of credits used, their distribution by income class, dwelling type, location of solar equipment, and administrative costs. Enforcement agencies in such states may informally assess the value of the incentive, but formal reporting requirements could form a rational basis for amendments or termination. Only California [64] and Arizona [65] statutorily provide for such monitoring and reporting, and these are states with definite termination dates.

\subsubsection{Deductions versus Credits}

Income tax incentives occur in two primary forms: deductions and credits. The primary distinction between the two is that the credit is applied against the total tax bill or net tax, while the deduction generally is applied against the gross taxable income, and affects the taxpayer's liability indirectly.

Deductions are also used for depreciation (the expensing of value lost through use of capital), and for rapid amortization (the extinguishing of tax liability through periodic payments). When deductions other than accelerated depreciation or amortization are allowed to corporations, they are known as investment tax incentives. Five states have expressly stated that use of either investment credits or deductions is in lieu of use of normal depreciation by businesses. Kansas has expressly allowed rapid amortization in addition to the deduction it offers [66].

Credits are favored by twelve states; general (nondepreciation) deductions of various kinds have been enacted by five states. There are several possible reasons for this preference for credits. First, the credits do not require itemization. Second, the amount of incentive available under a deduction will vary with tax rates, tax brackets, other available income, and additional factors which are unrelated to the solar device expense. A high-income-bracket applicant could benefit more (absolutely) by a deduction than might one who needs the incentive more, if the tax rates are progressive. In contrast, credits are considered more egalitarian. Third, credits are more commonly carried over if they exceed the tax liability of the applicant, which is a real possibility for low-income taxpayers.

Whenever the credit exceeds tax liability, potential for a rebate is created. A rebate is a powerful and immediate reinforcement for the solar consumer. Rebates could eliminate the need for a carryover, and are most effective in quickly reducing front-end costs, the greatest obstacle to solar purchasers. Only New Mexico [67] and Wisconsin [68] currently offer refunds when the tax credit exceeds the tax liability. Rebates accompanying tax credits are favored by the Solar Fnergy Industries Association [69].

\subsubsection{Measurement Formulae}

This segment compares the different approaches used by the states having income tax credits, deductions, and depreciation/amortization schemes. These basic formulae are discussed in the following paragraphs. The formula numbers referred to are described in the legend to Table 2-2. 


\section{Formula 1}

Alaska offers a residential fuel conservation credit for $10 \%$ of system expenses, with a maximum of $\$ 200$. Expenses include "installation of alternate sources of power generation not dependent upon fossil fuel." Presumably this includes costs such as labor, remodeling, and financing. This latter type of provision is found in only three other states-Colorado, Hawaii, and Wisconsin. Nonretroactive provisions are criticized by some authors [70]. Alaska also offers a 5\% residential fuel credit for the costs of wood, among other conventional fuels [71]. Installation expenditures must have occurred af ter 31 Dec 76. Such a nonretroactive provision is found in only three other states-Colorado, Alaska, and Wisconsin.

\section{Formula 2}

Arizona offers nondependent taxpayers one credit per residence equal to $35 \%$ of solar system cost, declining at $5 \%$ per year until 31 Dec 84 , with a total maximum of $\$ 1,000$. A five-year carry-over is provided [72]. In addition, a credit of $25 \%$ ( $\$ 100$ maximum) is provided for residential insulation, wind-driven turbine ventilators, and passive roof vents [73]. The distinctive features of this formula are two-fold. First, it is the only formula to distinguish between solar technologies by providing different benefits based on different costs for active and passive heating and cooling devices. Second, the incentive is spread over time, with two results. Solar consumers purchasing relatively inexpensive solar devices (e.g., hot water heaters) receive a potentially greater benefit by early acquisition (at least three years before termination), so that the formula can yield the maximum benefit. A formula that reduces tax liability a small amount each year while extending the benefit over time, will relatively favor lower income groups. The credit might exceed their tax liability in the absence of a carry-over provision, however, extended duration of the incentive does not solve the primary problem of front-end costs.

Arizona also allows a 36-month period to amortize the adjusted bassis of the costs of acquisition. This period was originally set at 60 months [74]. The election of amortization is in lieu of both depreciation and credit offerings [75].

\section{Formula 3}

Arkansas, Colorado, and Massachussetts allow deductions from gross income of the entire cost of the eligible solar device, including installation costs, but excluding interest and finance charges. Arkansas restricts the deduction for energy saving equipment to the year of purchase, and allows extremely broad administrative discretion in agency rule making [76]. The lack of specific definitions or examples of qualifying solar heating and cooling equipment in the Arkansas law is typical of many of the statutes considered herein.

Colorado also offers a deduction for the cost (including installation, construction, remodeling, and acquisition) of "alternative energy devices" that are in service in an occupied building. Heat pumps and fluid reservoirs are included in this definition [77]. The income tax deduction is uniquely considered a standard deduction for resident individuals [78], for most such deductions are itemized. Corporations are not entitled to depreciation if the deduction is taken [79]. 
The Massachussetts deductions for solar- or wind-powered "climatic control" or "water heating units" apply to corporations only, and are in lieu of depreciation [80]. Provision is made for taxation of capital gain or loss upon sale of the solar-equipped building, whereby the deduction is disregarded and straight-line depreciation is used as a computing basis. Labor costs are included, and performance certification is required.

\section{Formula 4}

Calif ornia offers a generous but short-lived income tax package [81]. The state allows a credit of $55 \%$ (maximum $\$ 3,000$ ) of the cost, including labor, installation, and energy conservation measures such as insulation, but excluding interest charges. Conservation measures are eligible if they reduce back-up or total costs, and can be installed up to two years after the solar system. In a nonsingle family dwelling where the cost exceeds $\$ 12,000$, the credit is $25 \%$. An open carry-over is provided until the credit expires on 1 Jan 81. In 1976 Calif ornia began offering a credit of $10 \%$, with a maximum of $\$ 1,000$, but amended the law in 1977 and 1978 to allow the greater credits [82]. Credits for the cost of purchasing solar easements are included since the passage of the Solar Rights Act of 1978 [83].

\section{Formula 5}

Hawaii simply allows a credit of $10 \%$ of the total cost of a "solar energy device," with an open carry-over period. The device must have been installed after $31 \mathrm{Dec} 74$ in order to qualify [84].

\section{Formula 6}

Idaho allows a deduction of the entire cost of the solar device over a four-year period [85]. Forty percent of the cost may be deducted in the year of purchase, and $20 \%$ per year in each of the following three years. There is a maximum limit of $\$ 5,000$ for any one year's deduction. The high first year deduction is well-suited to lowering front-end costs, and the extended time period assists low income purchasers. The deduction is limited to residential uses because state law already allows favorable depreciation treatment for income-producing property.

\section{Formula 7}

Kansas, New Mexico, North Carolina, and Oregon offer variations of a formula based on a $25 \%$ credit with a maximum of $\$ 1,000$. Kansas increases the maximum to $\$ 3,000$ for commercial applications [86]. The four-year carry-over for principal dwellings is not available for the commercial credits. Owners of income-producing property are expressly encouraged to amortize over 60 months in addition to use of the credits.

New Mexico [87] limits the applicability of its $25 \%$ ( $\$ 1,000$ maximum) credit to costs of equipment for solar heating or cooling of a residence, or solar heating of a swimming pool. Alternatively, the state offers a credit of $\$ 25,000$ (maximum) available over a three-year period, for a design-approved solar-powered irrigation pump system constructed on the taxpayer's or a partnership's property. The excess of credits over tax liability may be funded. 
North Carolina [88] does not distinguish between commercial and residential applications in its formula. It allows installation costs and a three-year carry-over for any single building or separately metered residence where the owner/controller pays the fuel bills.

In contrast to North Carolina, Oregon [89] limits its credit to one per taxpayer, rather than one per building. Under this statute, the system must provide $10 \%$ of the total energy requirements of the house in order to be certified. In addition, Oregon, as well as New Mexico and North Carolina, requires certification under the federal performance criteria [90]. Oregon's 10\% energy contribution provision could require detailed monitoring of solar energy installations, thus generating comprehensive data on the efficacy of solar installations. A large volume of installations, however, is likely to create administrative problems in ensuring the accuracy of monitoring.

\section{Formulae 8 and 9}

In 1977, Montana simultaneously passed two bills [91]. that created both income tax credits and deductions while terminating that state's solar property tax incentive. The legislative purpose was to encourage use of "alternative energy sources" through incentives requiring individual "initiative" [92].

Formula 8, Montana's credit system, allows a residential tax credit of $10 \%$ of the first $\$ 1,000$, and $5 \%$ of the next $\$ 3,000$ of the cost (including installation) of any "recognized non-fossil form of energy generation" which is "non-nuclear" [93]. 'I'he maximum available credit is $\$ 250$, with a four-year carry-over. However, similar federal credits have been passed, reducing the allowable credit to $5 \%$ on $\$ 1,000$ and $2.5 \%$ on the next $\$ 3,000$, whether or not the federal credits are claimed.

Formula 9, the Montana deduction provision, provides deductions upon application for residential or commercial "energy-related investments." The schedule tor residential capital expenses is: $100 \%$ of the first $\$ 1,000$ expended; $50 \%$ of the next $\$ 1,000 ; 20 \%$ of the next $\$ 1,000$; and $10 \%$ of the next $\$ 1,000$ expended; with a maximum deduction of $\$ 1,800$. For nonresidential buildings the business investment tax schedule becomes: $100 \%$ of the first $\$ 2,000 ; 50 \%$ of the next $\$ 2,000 ; 20 \%$ of the next $\$ 2,000$; and $10 \%$ of the next $\$ 2,000$; with a maximum of $\$ 3,600$. Deductible expenditures do not include offsetting grants or federal credits [94]. Presumably, subsidies may not be claimed under both formulae 8 and 9 by a residential owner.

\section{Formula 10}

North Dakota [95] allows a credit of $5 \%$ per year for two years of the cost of a "solar or wind energy device" which converts the "natural energy of the sun or wind." Eligible costs of acquisition and installation do not include alterations to the building structure. There is neither a maximum credit nor a carry-over provision. This relatively simple statute is the shortest such measure on record, creating no additional administrative machinery. The size of the North Dakota credit is one of the smallest available. By comparison, Hawaii offers $10 \%$ in one year; Alaska's credit is a maximum of $\$ 200$; and Montana's credit is a maximum of $\$ 250$, in addition to deductions. A study for the Federal Energy Administration by the National Conference of State Legislatures concluded that "regardless of system costs, incentives are not effective unless they create perceived discounts in excess of $25 \%$ " [96]. 


\section{Formula 11}

Oklahoma [97] offers a direct credit of $25 \%$ of the cost (including installation) of a solar energy system. This is a variation of formula 7 ; it is distinguished by a $\$ 2,000$ maximum, instead of $\$ 1,000$. As introduced, the bill allowed only an $8 \%$ credit [98]. A five-year carry-over for the credit is accompenied by a lenient definition of costs, including remodeling. Certification is required by the Department of Revenue, and field inspections by the Corporations Commission are authorized.

\subsubsection{Federal Action}

The most pertinent solar feature of the National Energy Act (NEA) is the Residential Energy Credit [99]. The credit is available to any "renewable energy source," including solar, wind, and geothermal energy equipment used in a taxpayer's principal residence. A refund up to $30 \%$ of the first $\$ 2,000$ and $20 \%$ of the next $\$ 8,000$ of system cost is provided. A credit is also allowed for energy conservation expenditures such as insulation, were incurred from 20 April 77 to 1 Jan 86. This credit allows $15 \%$ of the first $\$ 2,000$ expended.

California, New Mexico, and Montana are the only states which explicitly anticipated the availability of federal income tax credits under the National Energy Act of 1978. Nine other states passed income tax incentive legislation in 1977, just prior to the NEA. They either ignored the possibility of federal action, decided state incentives were independently needed, or preferred to respond retroactively, if at all.

California provides that if federal credits were forthcoming for eligible systems, the state's share would be reduced so that the maximum credit would not exceed 55\% (including carry-overs) [100]. New Mexico denies the residential building/pool/irrigationpump credit if any form of federal benefit is claimed on a federal tax return [101]. Montana simply halves its credit to $5 \%$ on the first $\$ 1,000$, and $2.5 \%$ of the next $\$ 3,000$ if a federal credit similar in kind (though not necessarily in amount) is made available, whether or not the federal credit is claimed [102]. Montana's deduction is unaffected, since only grants (federal, state, or private) are excluded from the costs eligible for the deduction.

\subsection{EXCISE TAX INCENTIVES: SALES AND USE, TRANSACTION AND PRANCHISE TAXES}

Excise taxes are generally synonomous with privilege taxes [103], which include sales, use, franchise, and transaction taxes. The sales tax is levied by state and local governments upon a purchase of, or on gross receipts from the sale of goods sold in-state. The use and consumption tax applies to goods being transported or stored in-state and which are not taxable via sales in the in-state chain of distribution. The franchise tax is defined as a tax on the privilege of corporate existence in a state. The transaction tax is closely related, and applies to the privilege of conducting business in the state [104].

Sales taxes are of particular importance because they are not of ten subject to the uniformity clauses present in most state constitutions [105], thus avoiding the constitutional obstacles confronting property tax exemptions. Although large-scale solar technologies may possibly be included in existing sales tax exemptions for building materials, utility energy supplies, industrial plants, energy use in manufacturing, or retail sales of energy 
(e.g., natural gas and electricity), it is usually held that exemptions must be conferred in plain terms [106]. The extent to which such exemptions apply is therefore unclear. Further, sales taxes do not generally apply to services [107], so labor costs for transportation, installation, and remodeling are automatically not taxed. In contrast, property and income taxes generally include such costs, so explicit exemptions, deductions, or credits are required.

The amount of any excise tax exemption varies considerably with the tax structures of the individual states. Such incentives are generally less substantial than the property, income, and loan incentives. Their economic impact becomes more significant when viewed in combination with the other incentives, especially when it is realized that excise tax exemptions-like income tax credits, generally reduce front-end costs, while most property tax incentives generally reduce constant costs. Noneconomic benefits of such tax breaks include publicizing solar energy, and enhancing industry credibility.

Only eight states (Arizona, Connecticut, Georgia, Maine, Massachussetts, Michigan, New Jersey, and Texas) have passed forms of excise tax exemptions. Except for Arizona and Michigan, the other six states have also provided for some type of sales tax exemption. Only Arizona and Michigan offer transaction or business activities tax exemptions. Texas is the only state to exempt corporations from franchise privilege taxes. Use, storage, and consumption tax exemptions are provided for in five of the eight states. The salient characteristics of the excise tax exemptions are listed in Table 2-3. Unique aspects and pertinent details of the laws of each state are discussed in the following paragraphs.

Arizona's transaction privilege tax exemption [108] allows corporations to avoid this tax. It applies to a wide variety of solar technologies and applications, including heat storage and irrigation. The use tax exemption [109] on tangible personal property repeats this same broad definition of "solar energy devices."

Connecticut offers a combination of sales and use tax exemptions [110], which apply only to solar "collectors" [111]. The state sales tax is currently $7 \%$, and the exemption has open duration.

Georgia passed one of the earliest sales tax exemptions in 1976. Georgia's measure originally favored solar "purchasers," but was amended to apply to the owner of the property to which the solar equipment is attached. This provision ensures that Georgia will not subsidize systems that could be inställed out of stule, or that dealer's of solar energy devices would be exempt from sales taxes on every device purchased for resale. To qualify, the owner must have his system certified and apply for a rebate [112].

Maine [113] passed a sales and use tax refund with its property tax exemption. Until 1983, the Office of Energy Resources will certify "solar energy equipunent" upon application. The applicant must include information on type of equipment, manufacturer; cost, seller, and use as a prerequisite to this exemption.

Massachussetts restricts its sales exemption to retail sales of solar equipment for use in an individual's principal residence [114]. The system may be either primary or auxiliary.

Michigan offers a sales or use tax combination [115] similar to Maine's and Connecticut's. The package has the longest statutorily determined duration (until 1985), and was one of the earliest such measures (1976). Eligible passive designs must not be similar to those found on unmodified (nonsolar) homes. Massachusetts has a similar 
Table 2-3. EXCISE TAXES

\begin{tabular}{|c|c|c|c|}
\hline State & Ariz. & Conn. & Ga. \\
\hline $\begin{array}{l}\text { Laws } \\
\text { Chapter No. }\end{array}$ & 42. 112 & 457 & 1030,1309 \\
\hline Year & 77. 78 & 77 & 76.78 \\
\hline $\begin{array}{c}\text { Codification } \\
\text { (Primary) }\end{array}$ & $\begin{array}{l}\text { ARS\$̧\&42- } \\
1312.01(A)(9), \\
42-1409(B)(9)\end{array}$ & $\begin{array}{l}\text { CGSA } \S \\
12-412 \text { (dd) }\end{array}$ & $\begin{array}{l}\text { GACA } \$ 92- \\
3403 \mathrm{a}(\mathrm{c}) \\
(2)(2.1)\end{array}$ \\
\hline $\begin{array}{l}\text { Eligible System } \\
\text { SHACOB } \\
\text { Passive } \\
\text { Hot Water } \\
\text { Wind } \\
\text { PV/TE } \\
\text { Hydro } \\
\text { Pump/Heat } \\
\text { Storage }\end{array}$ & $\begin{array}{l}8 \\
8 \\
8 \\
8 \\
8\end{array}$ & 0 & 0 \\
\hline $\begin{array}{l}\text { Type Excise } \\
\text { Sales } \\
\text { Transaction } \\
\text { Franchise } \\
\text { Use }\end{array}$ & - & 0 & $\bullet$ \\
\hline $\begin{array}{l}\text { Eligible } \\
\text { Owner } \\
\text { Purchaser } \\
\text { Seller } \\
\text { Corporation }\end{array}$ & - & - & • \\
\hline Refund & & & $\bullet$ \\
\hline $\begin{array}{l}\text { Duration } \\
\text { Effective } \\
\text { Expires }\end{array}$ & $\begin{array}{l}1977 \\
12 / 31 / 84\end{array}$ & $\begin{array}{l}1977 \\
\text { open }\end{array}$ & $\begin{array}{l}1978 \\
\text { open }\end{array}$ \\
\hline $\begin{array}{l}\text { Eligible Use } \\
\text { Residential } \\
\text { (Principal) } \\
\text { Agricultural } \\
\text { Industrial } \\
\text { Commercial }\end{array}$ & $\begin{array}{c}8 \\
\text { (Irrig.) } \\
8\end{array}$ & 8 & 8 \\
\hline $\begin{array}{l}\text { Apply } \\
\text { Certification }\end{array}$ & & & 8 \\
\hline
\end{tabular}


Table 2-3. EXCISE TAXES (concluded)

\begin{tabular}{|c|c|c|c|c|}
\hline Me. & Mass. & Mich. & N.J. & Texas \\
\hline 542 & 989 & 132,133 & 465 & 584 \\
\hline 77 & 77 & 76 & 77 & 77 \\
\hline $\begin{array}{l}\text { MRS } \$ 36- \\
1760-37\end{array}$ & $\begin{array}{l}\text { ALMc64H } \\
\text { §b(dd) }\end{array}$ & $\begin{array}{l}\text { MSA } \$ \$ 7.525 \\
\text { (8), } 7.555 \\
\text { (110) }\end{array}$ & $\begin{array}{l}\text { N.J.S.A. } \\
\text { C..54:32-B(fn }\end{array}$ & $\begin{array}{c}\text { Tax-Gen. } \\
\text { tit. } 122 \mathrm{~A}, \\
\{13.03 .1(1) \\
\end{array}$ \\
\hline 8 & $\begin{array}{l}8 \\
8 \\
8\end{array}$ & $\begin{array}{l}8 \\
8 \\
8 \\
8\end{array}$ & 8 & $\begin{array}{l}8 \\
8 \\
8 \\
8\end{array}$ \\
\hline - & $\begin{array}{c}\bullet \\
\text { (Retail) }\end{array}$ & $\bullet$ & - & 0 \\
\hline 0 & $\bullet$ & 0 & $\bullet$ & $\bullet$ \\
\hline - & & & & \\
\hline $\begin{array}{l}1977 \\
1 / 1 / 83\end{array}$ & $\begin{array}{l}1 / 30 / 78 \\
\text { open }\end{array}$ & $\begin{array}{l}5 / 27 / 76 \\
1 / 1 / 85\end{array}$ & $\begin{array}{l}7 / 1 / 78 \\
\text { open }\end{array}$ & $\begin{array}{l}8 / 29 / 77 \\
\text { open }\end{array}$ \\
\hline 8 & $\bullet$ & $\begin{array}{l}9 \\
0\end{array}$ & 8 & 8 \\
\hline 8 & & & - & \\
\hline
\end{tabular}

1 Excludes buildings owned by businesses in the solar resale business. 
qualification. The exemption suprisingly excludes equipment used on buildings that are owned by corporations engaged in the resale of solar devices.

New Jersey provides a sales and use tax exemption [116] for solar devices or systems that meet standards set by New Jersey's Department of Energy.

Texas is the only state offering a franchise tax exemption [117]. It applies to corporations engaged "exclusively" in the manufacture, sale, or installation of "solar energy devices," which are broadly defined. The exclusive condition would seem to deny the benefit to many large diversified corporations, although they would not be as substantially affected by the break (which exempts a $\$ 55$ minimum tax, or $\$ 4.25$ per $\$ 1,000$ of gross proceeds). 
SझP缍

1 


\title{
SECTION 3.0
}

\author{
LOAN AND GRANT PROGRAMS
}

\subsection{INTRODUCTION}

Loan incentives in the form of subsidized low interest loans and guaranteed or insured loans have a great potential to reduce both front-end and life cycle costs of solar systems [118]. Low interest loans administered by private or government agencies and financed by tax funds or tax-exempt revenue bonds can substantially cut long-term financing costs associated with the more expensive solar technologies. Guaranteed or insured loans can increase capital availability, allowing solar consumers to finance a larger share of the purchase, thereby reducing the critical initial cost. Low interest loans can more equitably benefit low income groups which are of ten charged higher interest rates. This benefit may be partially offset, because when similar interest payments are deducted from taxes, the benefit is relatively greater for those persons in the higher tax brackets.

\subsection{STATE PROGRAMS}

Eight states currently offer ten different loan or grant programs. With the exception of Montana, all of the programs were enacted in 1977 or 1978. Important features of each program are listed in Table 3-1; additional details and unique aspects are discussed in the following paragraphs.

Alaska has established an alternative power resource revolving loan fund in its Department of Commerce and Economic Development [119]. The loans are targeted for development of means of energy production including "windmills, water, and solar power devices." Thirty percent of purchase, construction, and installation costs may be loaned. The Department is required to develop eligibility guidelines.

California's original loan program [120] is a demonstration program benefitting victims of disasters result in a state of emergency being declared on or after 1 July 77. The 1978 legislation [121] was a response to the Santa Barbara fire in the summer of 1977. A $\$ 200,000$ loan fund is administered by the Department of Housing and Community. Development for solar improvements to damaged property on the original site. The program stresses solar water heaters, and seeks to generate data for the State Energy Resources Conservation and Planning Department on the energy-saving potential of solar equipment. Any tax credits available are assigned to reducing the loan balance. California had earlier attempted to implement a more comprehensive program financing residential installations of insulation and solar systems, to be administered by the State Energy Resources Conservation Development Commission and the Housing Finance Authority [122]. However, a $\$ 25$ million bond proposal to finance the program was defeated in the November 1976 election.

California also has a purchase program for military veterans [123]. Under the 1978 act, the market value limit of $\$ 43,000$ on buildings purchased by the Department of Veterans' Affairs for resale to veterans is raised to $\$ 48,000$ when "solar energy heating devices or equipment" are present as improvements in the building. 
Table 3-1. LOAN AND GRANT PROGRAMS

\begin{tabular}{|c|c|c|c|c|}
\hline State & Alaska & California & California & lowa \\
\hline Year & 1978 & 1978 & 1978 & 1978 \\
\hline $\begin{array}{l}\text { Law } \\
\text { Chapter No. }\end{array}$ & 29 & 1 & 1. 1243 & 1086 \\
\hline $\begin{array}{c}\text { Codification } \\
\text { (Primary) }\end{array}$ & $\begin{array}{l}\$ \S \S \mathbf{4 5 . 8 8} \\
010-.040\end{array}$ & $\begin{array}{l}\text { Health \& } \\
\text { Safety } \$ \S \\
41260-65 \\
50680-85 \\
\end{array}$ & $\begin{array}{l}\text { Mil. \& Vet. } \\
\$ \$ 987.64-92\end{array}$ & $\begin{array}{c}\text { 1.C. } \\
\S \S 220.1 \cdot .12\end{array}$ \\
\hline $\begin{array}{l}\text { Loan } \\
\text { Maximum } \\
\text { Interest } \\
\text { Fee } \\
\text { Repayment }\end{array}$ & $\begin{array}{l}\$ 10.000 \\
8 \% \text { max. } \\
20 \text { years }\end{array}$ & $\begin{array}{c}\text { (DEMO) o } \\
\$ 2.000 \\
0 \\
2 \% \\
30 \text { mos. }\end{array}$ & & \\
\hline Grant & & & 0 & \\
\hline $\begin{array}{l}\text { Source \& Type } \\
\text { Tax Fund } \\
\text { Bonds } \\
\text { Private }\end{array}$ & Dept.Comm.Mtg. & $\bullet$ & $\bullet$ & $\ddot{9}$ \\
\hline Tnsure & & & & \\
\hline $\begin{array}{l}\text { Eligible } \\
\text { Recipient }\end{array}$ & open & $\begin{array}{l}\text { disaster } \\
\text { victiiits } \\
(7 / 1 / 77 \text { on })\end{array}$ & Veterans & $\begin{array}{l}\text { Low/med. } \\
\text { income. } \\
\text { elderly. } \\
\text { disabled }\end{array}$ \\
\hline $\begin{array}{l}\text { Eligible Systems } \\
\text { SHACOB } \\
\text { Hot Water } \\
\text { Wind } \\
\text { PV } \\
\text { Bin/Hydro } \\
\text { Heat Pumn } \\
\text { Passive/Conservation }\end{array}$ & 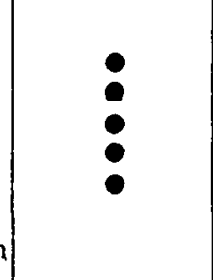 & $\begin{array}{l}0 \\
0 \\
0 \\
0\end{array}$ & $\begin{array}{l}0 \\
0 \\
0 \\
0\end{array}$ & $\begin{array}{l}\bullet \\
\bullet \\
\bullet\end{array}$ \\
\hline Building & & Res. & Res., Ag. & Res. Rehab. \\
\hline Duration Program & & 1980 & open & open \\
\hline Min. Energy Req. & & & & \\
\hline Standards & 0 & & & - State \\
\hline $\begin{array}{ll}\text { Key: } & \text { Res. - Residentia } \\
& \text { Rehab. - Rehab }\end{array}$ & bilitation & $\begin{array}{l}\text { g. - Agricultura } \\
\text { nd. - Industria! }\end{array}$ & \multicolumn{2}{|c|}{$\begin{array}{l}\text { Fed. - Federal } \\
\text { Cert. - Certification } \\
\text { Mtg. - Mortgage }\end{array}$} \\
\hline
\end{tabular}


Table 3-1. LOAN AND GRANT PROGRAMS (concluded)

\begin{tabular}{|c|c|c|c|c|c|}
\hline Mass. & Minn. & Montana & Oregon & Oregon & Tennessee \\
\hline 1977 & 1977 & 1975 & 1977 & 1977 & 1978 \\
\hline 28. 73 & 401 & 548 & 315 & 732 & 884 \\
\hline $\begin{array}{c}\text { ALM c168 } \\
\$ 35(10)\end{array}$ & $\begin{array}{c}\text { MSA 462A } \\
.05(14-15)\end{array}$ & $\begin{array}{l}\text { MRCA } 84 \\
7405\end{array}$ & $\begin{array}{l}\text { ORS\$ } \\
407(2)\end{array}$ & $\begin{array}{l}\text { Const. Amend } \\
\text { lincodified }\end{array}$ & $\begin{array}{l}\text { TCS } \$ \$ 1,3- \\
2303.2316\end{array}$ \\
\hline \begin{tabular}{|c|}
$\$ 15.000$ (bks) \\
$\$ 2000$ add (other) \\
Prevailing \\
\\
Max. 10 yrs.
\end{tabular} & $\begin{array}{c}\text { Market value } \\
\text { Varies }\end{array}$ & 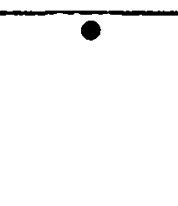 & $\begin{array}{l}\$ 3000 \\
\text { (add.) } \\
\text { Varies } \\
30 \text { yrs. }\end{array}$ & - & Varies \\
\hline & - & & & & \\
\hline - & - & utility & $\bullet$ & - & \\
\hline & & & & & 0 \\
\hline Anyone & $\begin{array}{l}\text { Low/med. } \\
\text { income; } \\
\text { Owners }\end{array}$ & & $\begin{array}{l}\text { Loanee, war } \\
\text { Vet Fund }\end{array}$ & $\begin{array}{l}\text { Utility } \\
\text { and/or } \\
\text { Designee }\end{array}$ & $\begin{array}{l}\text { Low or Mod. } \\
\text { Income }\end{array}$ \\
\hline $\begin{array}{l}0 \\
: \\
: \\
0 \\
0\end{array}$ & - & 0 & $\begin{array}{l}0 \\
\bullet \\
0 \\
0\end{array}$ & $\begin{array}{l}\bullet \\
\bullet \\
\bullet \\
\bullet \\
\bullet\end{array}$ & $\begin{array}{l}0 \\
0 \\
0\end{array}$ \\
\hline & Res.. Rehab. & Res. & Res. & Res.. Ag. & $\begin{array}{l}\text { Ind. Kes/ } \\
\text { Res. Rehab }\end{array}$ \\
\hline \multirow[t]{3}{*}{ open } & open & & open & 30 years & open \\
\hline & & & $10 \%$ & & - \\
\hline & & & Cent. & & red. \\
\hline
\end{tabular}


Iowa has authorized its housing finance authority to make "property improvement loans" for the improvement or rehabilitation of (1) housing deemed substandard in its structural, plumbing, heating, cooling, or electrical systems; or (2) any housing to increase its "energy efficiency" or to "finance solar or other renewable energy systems for use in that housing" [124]. The state may condition the loan upon bringing the building into compliance with the thermal efficiency standards in the state building code.

Massachusetts' loan provision [125] increases the maximum amounts and repayment period for mortgage loans financed by private institutions other than banks, on the condition that at least $\$ 2,000$ of the loan is for the purpose of financing the purchasing and installation of a solar, wind-powered, or heat pump system. The maximum repayment period for loans is extended to 10 years. Maximum amounts for qualifying solar loans are increased to $\$ 7,000$ for cooperative banks and trusts, and to $\$ 9,500$ for credit unions. In 1978 , Massachussetts authorized bank loans of up to $\$ 15,000$ for purchase and installation of solar, wind-powered, or heat pump systems [126].

Minnesota amended the specific powers of its Housing Finance Agency to allow grants for repayment of loans, and to provide loans for rehabilitation of residential buildings occupied by persons of low or moderate income, if one purpose of the loan is to "accomplish energy conservation related improvements" [127]. This phrase is not statutorily defined, but a good argument can be made that it functionally includes solar systems. A related bond measure raises $\$ 175,000$ for rehabilitation loans in general [128].

Since 1975, Montana has allowed electric or natural gas utilities to extend credit to customers to pay for "installation of energy conservation materials in a dwelling" [129]. The customer can repay the debt through monthly bills, with a maximum interest charge of $7 \%$ on the declining balance. The utility is reimbursed for the difference between $7 \%$ and the prevailing interest rates on home improvement loans through a credit against its license tax liability. An "energy conservation purpose" is defined as "reducing waste or dissipation of energy, or reducing the amount of energy required to accomplish a given quantity of work" [130]. While this certainly applies to weatherization techniques like insulation and storm windows, conceivably energy-efficient solar technologies or passive methods could fit the latter part of the definition.

Oregon has enabled a recipient of a 30 -year, $\$ 42,500$ War Veteran's Loan to receive a subsequent loan up to a maximum of $\$ 3,000$ for the "purpose of installing an alternative energy device for a home" [131]. The device must be certified for compliance with standards authorized under the act which require the system to produce at least $10 \%$ of the total energy consumption of the home. Oregon also passed a constitutional amendment [132] that would put into effect a law [133] changing the limits on offering general obligation bonds for state power development. The bonds would be available to. individuals or electric utilities, alone or in combination, for undertaking "alternative energy projects." Eligible projects include "conversion or development of an energy resource into a usable non-electric form of energy" [134].

Tennessee has empowered its Housing Development Agency to facilitate or to directly make loans for energy saving improvements and solar hot water heaters to low and moderate income persons and families in residential housing [135]. For insured residential rehabilitation construction loans, the costs are to be included in the loan only "if feasible" [136]. Repayment schedules for loans to low or moderate income recipients are intended to conform to savings reflected in their utility bills. Energy-conserving designs are to be given "maximum consideration." Standards identifying reliable and efficient solar hot water heaters are to be provided by the appropriate federal agency. 


\subsection{NATTONAL ENERGY ACT}

The National Energy Act has several provisions designed to stimulate private lending and lessen the need for additional state loan programs [137]. In addition to $\$ 800$ grants to low income families and farmers for weatherization, loan insurance for energy conserving improvements (including active or passive solar methods) will be available under Title I of the National Housing Act. Limits on federal mortgage insurance are increased $20 \%$ where a building has solar equipment installed.

Another section of the Act authorizes the Government National Mortgage Association (GNMA), under the direction of the Secretary of Energy, to purchase loans that are made to low and moderate income families for the installation of energy conserving improvements in one- to four-family dwellings owned by such families. The loan cannot exceed $\$ 2,500$ and must have a repayment term of 5 to 15 years. The total amount of outstanding loans the Secretary is authorized to purchase will be determined by appropriation acts, but shall not exceed $\$ 3$ billion. The GNMA is further authorized to purchase similar loans when the Secretary finds that insufficient credit for such loans is available on a national basis. For these unsubsidized loans the amount appropriated cannot exceed $\$ 2$ billion [138].

A more simple and effective system could be devised by establishing a direct-loan federal bank, whose loans would be unrelated to existing federal assistance programs. Financing could derive from the subsidies enjoyed by other energy services or taxes, upon removal of price controls. 
SEPI暲 


\section{SECTION 4.0}

\section{STANDARDS AND WARRANTIES}

There is a small body of state legislation authorizing or requiring solar standards apart from standards related to the tax incentives previously considered; e.g., standard compliance as an eligibility requirement for an income tax credit. In general, standards apply directly to solar equipment, while the closely related building codes apply to building characteristics that affect solar utilization. The major overlap between standards and codes occurs when the solar system is passive or structurally integrated into a new building, in which case an energy conservation code could dictate the performance standards necessary for the solar system.

Warranties are related to standards in that both warranties and standards are designed to inform the purchaser of the existence, or absence, of qualities or characteristics of the merchandise. But warranties are a seller's obligation, while standards are the state's assurance to the consumer of the quality or performance of the product. Warranties may also be required in association with performance standards or performance test certification.

\subsection{STANDARDS}

\subsubsection{Policy and Authority}

The role of standards in commercialization of solar energy is almost as controversial as the question of utility involvement. Consumers expect reliability, durability, and efficiency from solar systems in order to insure that the systems will effectively generate life-cycle savings. Manufacturers face a proliferation of nonuniform standards; compliance in design, testing, and certification can be an expensive proposition [139]. The protlem is cumpunuled by uncertaintles as to the potential scope of application, since some statutes contain ambiguous definitions.

National regulatory schemes such as the Housing and Urban Development (HUD) Minimum Properly Stundards (MPS) for Solar Heating and Domestic Hot Water [140], and the National Aeronautics and Space Administration (NASA) National Bureau of Standards (NBS) Interim Performunce Criteria [141] may facilitate national marketing. The MPS apply to all housing constructed under HUD mortgage insurance and low-rent housing programs. The Interim Performance Criteria are still provisional, apply only to federal demonstration programs, and are to some degree insensitive to regional variations in appropriate technology.

In addition to adoption of federal standards, state and local action has been limited-but diverse. The result has been the creation of varying regulatory schemes that have become the basis of consumer expectations, as well as market obstacles to solar manufacturers.

Legal challenges to state standards are increasingly likely as more national firms and distributors enter the solar market and confront a multiplicity of state and local standards. State and local standards may be attacked as an unconstitutional interference with interstate commerce. But legislative findings of necessity for the protection of 
public health, safety, and public revenues, when coupled with Congressional acquiesence, are given great weight by the courts. In such circumstances, courts are likely to presume constitutionality. The solar industry would prefer to create national trade association standards, instead of facing more state or federal regulations.

\subsubsection{Types and Sources of Standards}

There are three major types of standards: testing, materials, and performance. Testing standards control the process of ascertaining compliance with materials and performance standards. Materials standards specify certain types and qualities (such as durability) of equipment components, and are likely to be complemented by building codes. Performance standards address the operational characteristics of equipment in terms of efficiency and output. They are the most realistic and functional standards, theoretically accommodating a wide variety of technologies.

Standards commonly have three sources: (1) equipment definitions in tax incentive legislation, or de facto standards [142]; (2) explicit mandates in standard legislation; and (3) relevant sections of building codes.

\subsubsection{State Standards}

While it is difficult to distinguish certain standards from codes, the equipment/building dichotomy provides a convenient distinction. In the case of passive solar systems, however, equipment is governed by standards; buildings by codes.

Apart from states that have passed tax incentive-related standards, only five states have passed distinct "standard" legislation: California, Connecticut, Florida, Minnesota, and New Mexico [143].

California has authorized the State Energy Resources Conservation and Development Commission to "develop and adopt, on or before November 1, 1978, in cooperation with affected industry and consumer representatives, regulations governing equipment associated with the collection, transfer, and storage and control of solar energy" [144].

The Commission is required to hold public hearings prior to rule making. Authorized regulations may include minimum standards for testing, inspection, certification, sizing, and installation of solar devices. Enforcement and compliance verification procedures include accreditation of laboratories, certification, on-sile inspections, submission of test data, and prohibitions on the sale of solar devices that do not meet safety and durability requirements. The Commission must consider the costs and benefits of the standards and regulations, and may not interfere with a system developed and installed on private property. It will also develop designs for prototype passive houses for mass market deployment. Federal standards are suggested as guidelines.

In contrast to the legislative specificity of the standards in the California statute, Connecticut has delegated broad authority to its Commissioner of Planning and Energy Policy [145]. The Commissioner's duties are "by regulations, to establish standards for solar energy systems, including experimental systems, which offer practical alternatives to the use of conventional energy with regard to current technological feasibility and the climate of this state." 
Where there is no administrative history of rule making in a regulated area, the need for specific legislative standards is especially important. The wide latitude that exists with regard to regulatory details could allow the Commissioner to adopt either material or performance standards. Further, the words "practical alternative" could be interpreted to have an economic as opposed to technical meaning, limiting the number of technologies susceptible to regulation. The condition of suitability to local climate could limit the types of systems to be considered, or result in the adoption of standards that are distinctly local, potentially impeding the flow of interstate commerce. Reference to federal standards would minimize this problem.

Florida's Solar Energy Center was authorized by the Solar Energy Standards Act of 1976 to "develop standards for all solar energy systems manufactured or sold in the state" [146]. The standards are designed to ensure that the systems represent a "high level of quality of materials, workmanship, and design." Establishment of performance criteria is also required.

The Center has adopted a Bturoutput test for flat-plate collectors that is designed to be compatible with national standards, while using the conditions of a Florida day as a measure. Performance testing capabilities are developed within the center, which may charge fees for the service. A unique statutory provision, also administratively adopted in Calif ornia, allows reciprocity in accepting results of tests conducted elsewhere, if the criteria conform to Florida's. Finally, the Florida legislature amended the certification procedure in 1978 to make certification and the display of certification labels mandatory [147].

Minnesota has authorized the Building Code Division of the Department of Administration to establish rules concerning "quality and performance standards" to be incorporated into the state building code. The criteria are to be in "reasonable conformance" with the Interim Performance Criteria of NASA and NBS. The Minnesota energy agency is to be consulted prior to standards modification, which may occur after 1976, as new technologies and materials become available. The standards are designed to "insure that within the existing state of development, solar energy systems... are effective and represent a high quality of material, workmanship, design, and performance" [148]. In contrast to Florida, the standards apply to systems "sold and installed" in-state, not just those sold or manufactured in-state. Vendors need not display the result of quality standard testing, but are required to inform a "bona fide potential purchaser" of such results.

New Mexico has delegated to the Regents of the state university the tasks of developing "solar equipment performance standards for solar energy development," and "test[ing] solar heating and cooling systems" [149]. This bare-bones mandate accompanied an initial appropriation of $\$ 500,000$, which will also be used for other solar promotional activities.

\subsection{WARRANTIES}

\subsubsection{Sources and Definitions}

Like standards, warranties serve to create and reinforce consumer expectations as to product reliability. By assuring consumer confidence in the solar industry, warranties can stimulate market devclopment for solar products, provided that warranty costs are not prohibitive. 
The term warranty generally refers to a seller's obligations to the purchaser with respect to the quality of merchandise. Implied warranties for solar "goods" can exist, despite the absence of an express warranty, in the majority of states adhering to the Uniform Commercial Code (UCC). Warranties of fitness for a particular purpose [150], or of general merchantability [151] may be implied.

Express warranties are affirmations of fact that become part of the basis of the bargain of purchase and sale. They arise by writing, promises, descriptions, or proferring samples [152]. Express warranties are most of ten used to limit the seller's liability by serving as replacements for broader implied warranties. The federal Magnuson-Moss Warranty Act requires full disclosure of the extent of a seller's obligations under a written warranty [153]. Unlike the UCC, violations under this Act are of ten resolved in nonjudicial forums, increasing the practicality and availability of a consumer's remedy. However, the definition of a consumer under Magnuson-Moss includes only a buyer for personal, family, or household use; a buyer for commercial applications is unprotected.

\subsubsection{Programs and Policy}

Warranty programs are in place in California (tax-related), in New York and under the HUD Cycle 4 Hot Water Initiative. But warranties have been criticized as too difficult to enforce, too expensive to apply, and too burdensome for small companies seeking market entry. Problems with installations are a major reason for poor performance of solar energy systems, but warranties rarely cover installation. Moreover, solar energy systems of ten have components made by several different manufacturers. Therefore, an owner of such a system which is malfunctioning must deal with numerous manufacturers. Enforcing a warranty under these conditions is extremely hard since it may not always be clear which component is failing to perform. Proposals are being made to establish a voluntary National Solar Warranty Insurance Program, which would establish meaningful warranties and back them up in case the system vendor fails to live up to their terms [1541,

\subsubsection{State Warranticu}

New York is the first and only state to pass a Solar Energy Products Warranty Act [155]. Recognizing the limitation of the Magnusun-Muss Aet protections to noncommercial users, the legislature declared that warrunty protections "should be made available to all purchasers of solar energy products in this state, regardless of use."

The Act requires all solar purchases to be made in writing and signed by both parties. It does not require that a warranty be provided, but the absence of a warranty must be conspicuously noted. The main requirement provides thut the contract shall contain a projection of the minimum thermal performance characteristics of the system, and the supplemental energy required.

The New York law is unlike a standard in that it does not require conformance to any performance level, but rather publicizes the performance level achieved under the mandatory testing procedures that will be prescribed by the Commissioner of Energy. The tests are to rely on local conditions of mean solar radiation and ambient temperatures, as listed in the HUD Intermediate Minimum Property Standards for Solar Heating and Domestic Hot Water. System owners are authorized to bring suit for actual damages under the Act, if the state attorney general has not commenced proceedings. Attorney's fees are also recoverable under the Act. 


\section{SECTION 5.0}

\section{BUILDING CODES}

Building codes have been described as "barriers" and "burdens" upon innovative energy technologies and conservation techniques by two leading studies of the subject [156]. As with standards, a major problem is the diversity of codes. This nonuniformity stems primarily from local variation in code content, despite the existence of at least five national building code organizations and statewide codes in several states. Local codes that follow national trade group codes do not always (or quickly) reflect recent amendments accomodating new technologies or policies.

Specific code provisions can impede installation of noncomplying solar systems. Where codes are not directly applicable, local enforcing officials are left with wide discretion. Even when codes are explicit or directly applicable, lack of familiarity with solar systems by code officials can cause misinterpretation or overprotection of perceived local customs and property values. Yet, codes can be a positive factor in solar commercialization, particularly when provisions facilitate access to sunlight or retrofitability of houses.

Across the country, code officials are confronting relatively new solar energy applications on an administrative level. Not many state legislatures have yet addressed the issue with regard to publicly owned buildings. The major state emphasis has been on adoption of statewide energy conservation codes in response to federal legislation. Such codes infrequently apply to active systems for solar heating and cooling of buildings. The indirect effect of these conservation codes, especially upon passive design and technologies, is a complex subject beyond the scope of this paper, with the exception of one example (Utah) discussed in Segment 5.4. Otherwise, conservation codes are included only where solar energy is explicitly referred to.

\subsection{ACCESS}

In 1976, California passed a law that allows any city or county to require that new residential buildings subject to the state housing laws be "constructed in a manner permitting installation of solar heating, including, but not limited to, a roof pitch and directional alignment suitable for retrofitting" with solar devices [157]. Normally, California cities and counties are required to adhere to the regulations of the Commission of Housing and Development, which in turn rely on a private uniform code. San Diego County has recently passed an ordinance, over construction industry objection, requiring southern roof aspects on new homes [158]. Local freedom exists as to the choice of range of permissible roof pitches and alignments, so long as efficiency of collection is maximized.

\subsection{RETROFITABILITY}

In contrast to the California approach stressing the potential access to sunlight, Florida has facilitated mechanical retrofitability by requiring plumbing hookups in new residential construction for solar hot water equipment. The provisions are mandatory, as opposed to the California local option. This is perhaps due to the less radical effect of plumbing retrofitability on aesthetics and zoning height limits. The 1974 Florida law applies only to new single-family buildings and prohibits their construction if the 
plumbing design does not include "the provision of readily accessible piping to allow for pipe fittings that will allow easy future connection into the system of solar water heating equipment." The legislative intent was to "minimize the cost of rearranging plumbing should solar water heaters be added to buildings" [159]. An administrative interpretation now requires that a common " $T$ " pipe be accessible from the inlet water pipe of the conventional water heater.

\subsection{ENCOURAGEMENT}

Nevada has authorized energy conservation standards that apply to all buildings in the state. The Public Works Board was directed to establish provisions for granting "design and construction allowances to the extent solar, geothermal, wind or other nondepletable energy sources are used to supply all or a part of the energy requirements of a public or private building" [160]. Conservation standards governing space heating, ventilation, airconditioning of buildings, and water heating were to be established by 1 Jan 78 . Buildings erected after 1 July 78 are subject to the new standards, which must be incorporated into the building codes of any city or county. Cities and counties are authorized to adopt more stringent standards.

\subsection{CONSERVATION}

In Utah, the 1976 legislature required the State Building Board to adopt an energy conservation construction code to promote the use of "energy systems that will provide satisfactory effects with less energy, with alternative energy sources, and with reasonable costs" [161]. In the following year, an amendment extended the scope of application of the standards to "any buildings requiring a building permit from any political subdivision," as well as to state education facilities or state-owned buildings [162]. These energy conservation construction provisions will indirectly affect solar energy development. 


\section{SECTION 6.0}

\section{ACCESS TO SUNLIGHT}

\subsection{THE PROBLEM}

Whenever a solar device or system is planned or installed, the owner confronts the problem of ensuring access to sunlight. Direct access to solar radiation is at least as essential to proper performance as design, materials, installation, or maintenance. Access is reflected in many factors affecting the desirability and suitability of solar applications. Life-cycle cost-benefit analysis is predicated upon effective use over a substantial period of time. Tax benefits are occasionally conditioned upon actual use or minimum energy requirements (see Tables 2-1 and 2-2). Capital availability for financing solar home mortgages or loans could be constricted due to lender/insuror uncertainty as to the estimated payback period and total energy savings achieved as reflected in the ultimate market value of the house. Even partial diminution of access to sunlight caused by growing vegetation or new buildings could adversely affect operation of or plans for a solar system.

The potential severity of the access problem varies with both the local density of development and with the specific technology. Densely developed areas hold the largest number of potential land-use conflicts, because most solar applications will be roof top retrofits amid buildings of various heights in zoning areas allowing future high-rise construction. However, the immediate magnitude of the problem in such areas is very small due to the smaller number of actual solar applications.

In less-dense suburban/residential areas, potential shading problems are not as likely to be encountered because of the historical effect of restrictive height and set-back zoning restrictions. Vegetation problems are likely to be more severe in low density areas. Wind energy systems requiring horizontal easements for wind corridors present a different set of access issues due to directional variation and other factors, and are welldiscussed in the Mayo study [163].

In both high and low density situations, the potential access problem for solar thermal applications will be minimized if the technology is relatively mobile and less consumptive of surface area. Side-yard solar hot water heaters may give rise to fewer access disputes compared to larger stationary active or passive systems. More efficient collector systems and passive designs can cut the total surface area or profile required for the same energy output.

Newly designed buildings with integrated solar systems present an opportunity to avoid shading problems by proper location, assistance from zoning laws, and solar "building envelope" codes. Existing buildings in areas subject to infilling are most vulnerable to sunlight interruption. There is very little empirical information available as to the magnitude of the shading problem. Several aerial surveys indicate that actual shading problems are not very great in Colorado Springs, Colorado (low density) and Long Island, New York (medium-high density), although in the latter case, half of the buildings were unsuitable for retrofit with roof top solar hot water heaters due to structural or other problems [164].

The access problem, then, is a long-term one. It has little immediate significance in the context of overall interference with energy consumption, because the present use of 
solar energy is relatively small. However, the potential problem is large and almost universal due to the diagonal nature of sunshine across traditionally vertical property boundary dimensions [165]. As dependence on solar energy increases, interference with solar access could be devastating to planning, economics, or even comfortable survival. The severity of the problem where it does exist, coupled with a certain theoretical complexity and appeal, accounts for the excessive numbers of law review commentaries devoted solely to solar access problems.

\subsection{AVAILABLE REMEDIES}

The common law in America affords little protection from supply interruption for an existing solar application. American property law generally rejects the English Doctrine of Ancient Lights, which only allowed continued access to enough indirect light to illuminate an interior living area. Most jurisdictions have followed the famous Fontaincbleau case [166] in finding this doctrine ill-suited to the growth-oriented economy and lower population density of America. Similarly, "prescriptive easement.s" to light and air are not generally accepted in the United States, although occasionally a prescriptive scenic easement is allowed [167].

A third possible remedy for obstructed access to sunlight or wind is available in the law of nuisance. To prove "private" nuisance, one must generally show a continuous and substantial invasion of an interest in land of a nature that would be labeled "unreasonable" by community standards. Irreparable damage must also be evident, and the hardship imposed by the nuisance must be greater than the hardship that would be imposed by enjoining the defendant's nuisance. Moreover, an injunction forbidding further interference is unavailable in many jurisdictions, which rely on monetary damages as a remedy. The private nuisance approach to preventing interference with access to sunlight was rejected in Fontainebleau and in several analogous radio and TVwave interference cases [168].

A "public" nulsance arises from interference with general community-wide interests. California has already acted by declaring shading of solar collectors to be a public nuisance [169]. A private suit asserting a public nuisance arising from blocked sunlight would be difficult to maintain unless the actual injury is widespread and the obstruction is not authorized by zoning regulations. Most legal authors seem pessimistic about the viability of nuisance actions, according to a survey by the Environmental Law Institute [170]. Of course, legislation declaring that interference with sunlight falling on solar collectors is a public nuisance, is an obvious possibility that could be considered as a valid exercise of the police power for the protection of public health, safety, and welfare, if retroactive application was preventer.

'l'hus, continued access to sunlight for an owner of a solar system will necessarily depend upon explicit private contractual agreements or new forms of statutory protection. Traditionally, landowners have negotiated easements or restrictive covenants with neighbors for a variety of purposes, including placement of utility lines and protection of scenic views. Easements and covenants are of ten created by a developer for the benefit of each lot prior to subdivision and sale. Solar easements or covenants are similarly capable of private creation and enforcement.

There are important problems associated with easements and covenants, however. They can be prohibitively expensive in the case of airspace in high rise areas where development is still possible. Leasing the easement for shorter periods may then become a cost- 
effective alternative. Easements are considered to be encumbrances on land titles, conceivably reducing the market value of the burdened land and restricting the transferability of title or freedom of alienation of future owners. And of course, the problem of the unreasonable holdout may always arise.

Similarly, restrictive covenants and housing associations function like private zoning laws, and can potentially be used to defeat proposed solar applications on aesthetic grounds. However, the first case contesting an aesthetic covenant's negative application to a solar system has just resulted in the demise of the covenant as being antagonistic to public policy. This California case may have a significant impact upon future controversies in this area [171]. Even if covenants favored solar access and included rights to sunshine flowing across the property of each southern neighbor, the southernmost resident in the association might still be left unprotected.

\subsection{THE LEGISLATIVE RESPONSE}

State legislation regarding solar access has been primarily concerned with regulating the creation and recording of private voluntary easements and covenants. To date, twelve states have passed laws governing the content and recording of solar easements: Colorado, California, Florida, Georgia, Idaho, Illinois, Kansas, Maryland, Minnesota, New Jersey, North Dakota, and Virginia. Criticism of these laws has centered on the idea that they are premature due to the absence of widespread solar utilization, and/or unnecessary, because private easements for access to sunlight could be voluntarily created regardless of the existence of such laws. Proponents argue that the legislative recognition of easements will (1) facilitate private enforcement, (2) provide a more uniform system of conveyancing and recording that lessens any adverse effects upon title or marketability, and (3) cause the parties to deliberate more fully the details and consequences of such transactions.

Four states (Connecticut, Minnesota, Oregon, and California) have passed laws incorporating solar considerations into zoning and land-use planning processes. Public zoning and land-use planning, coupled with proper orientation of the structure or appropriate placement of collectors, is a very promising means of guaranteeing solar access for newlybuilt structures in the future, but will have little effect upon existing buildings. California's nuisance law, discussed in Segment 6.3.4, is in effect a land-use planning device.

Finally, New Mexico has passed a controversial law declaring access to solar energy to be a property right that is henceforth governed by the principle of prior appropriation. The 18 various laws relating to access will be discussed and compared in detail in the following segments.

\subsubsection{Easements}

Colorado passed the first law governing solar easements in 1975 [172]. The law requires that the easement be created in writing (to satisfy the statute of frauds), and be subject to the same conveyancing and recording requirements as other easements [173]. The minimum contents of the writing that creates the easement are: (1) vertical and horizontal angles, expressed in degrees, at which the solar easement extends over the real property subject to the easement; (2) any terms or conditions of grant or termination; and (3) provisions for compensation of the owner of the benefited property in the event 
of interference with the enjoyment of the easement, or for compensation of the owner of the burdened land for maintaining the easement.

The Colorado statute is a prototype law, serving as a model for many of the other laws considered below. Even though the law requires that the easement include the vertical and horizontal angles of the solar easement, there is no agreement on the point from which the easement angles are to be measured, which is important in the case of movable collectors where the angle of collection can be changed.

A general rule for proper collector tilt (vertical angle) is that it should equal the site latitude plus or minus $10^{\circ}$. Collectors should be oriented (horizontal angle) at true south, plus or minus $20^{\circ}$.

Calif ornia passed a comprehensive Solar Rights Act in late 1978, which rerognized solar easements as "the right of receiving sunlight upon or over land" [1741. Minimum provisions for a valid easement include a description of the dimensinns of the pasement in "measureable terms." This can be by angular degrees, as Colorado's statute requires, or by times of day during which the collector is to be unshaded, or both. Another requirement is specification of restrictions placed on vegetation or structures that might interfere with sunlight. The vegetation provision is reinforced by the Shade Tree Control Act, which is discussed in the following paragraphs. Solar energy systems for which easements may be created include active solar heating and cooling (SHAC) systems and passive structural design features which have a useful life of at least three years.

Florida's 1978 law establishing mandatory solar equipment standards also provided for the creation of solar easements and remedies for interference with them as part of the general real property law $[1751$. In addition, Florida requires a description of (1) the properties involved, (2) the existing boundaries and setbacks required by zoning, and (3) the point from which the angles are to be measured. The law was effective beginning 1 Oct 78, and applies to structures on which building commenced after that date.

Georgia passed a Solar Easement Act of 1978, which included a declaration encouraging solar energy that should be useful in judicial recognition of a legislative policy facilitating valid solar easements [176]. It requires at minimum that the easement dosuments include a "definite and certain description of the airspace affected by such easement," but does not provide a standard type of measurement. The only other boiler plate is a listing of terms of easement grant or termination.

Idaho also passed a solar easement law in 1978 [177]. It is virtually identical to the Colorado law except that it adds a section governing transfers of easements, which states that the easement "shall be presumed to be attached to the land on which it was first created, and shall be deemed to pass with the property when title is transferred." In property law parlance the easement is thus considered to be appurtenant to the servient estate, with the burden "running with the land," so that a future inheritor or grantee is assured of the continued existence of the easement.

It is questionable whether this provision should be a requirement. Even if it were not required by Idaho law, the parties could still agree to a long-term solar easement, but they would also have the choice of not encumbering the land on a long-term basis. Most easement owners probably should seek a long-term guarantee that extends over the life of the solar system or structure, but they may wish to negotiate separately with a future owner, perhaps at a lower price. 
Illinois has taken an indirect and cumbersome approach to recognizing and regulating "solar skyspace easements." In the Comprehensive Solar Energy Act of 1977, Illinois accomplished its regulatory purpose merely by defining the content of a solar skyspace easement, without indicating whether the easements are subject to conveyancing laws, tax credits, or exemptions [178].

First, such an easement is stated to be part of a solar energy system, which includes "any legal, financial, or institutional orders, certificates, or mechanisms, including easements, leases, and agreements, required to ensure continued access to solar energy, its source, or its use ..."[179]. "Solar skyspace" is defined as "the maximum three-dimensional space extending from a solar energy collector to all positions of the sun necessary for efficient use of the collector" [180]. The solar skyspace is divided into heating and cooling categories: "heating" skyspace means the maximum three-dimensional space extending from a solar energy collector to all positions of the sun between 9 a.m. and 3 p.m. Local Apparent Time from September 22 through March 22 of each year; cooling skyspace only encompasses the hours from $8 \mathrm{a} . \mathrm{m}$. to $4 \mathrm{p} . \mathrm{m}$. between March 23 and September 21. It may be questioned whether some heating might not be needed during the statutory cooling period and vice versa due to common climatic fluctuations. Under the Illinois arrangement, water heaters, tracking collectors, and solar greenhouses, which can use sunlight at hours other than those indicated, are not adequately provided for. The reference to Local Apparent Time is useful, however, where Daylight Savings Time is relied upon.

Finally, the statute defines an Illinois "solar skyspace easement" as:

a right, whether or not stated in the form of a restriction, easement, covenant, or condition, in any deed, will or other instrument executed by or on behalf of any owner of land or solar skyspace or in any order of taking, appropriate to protect the solar skyspace of a solar collector at a particularly described location to forbid or limit any or all of the following where detrimental to access to solar energy: (a) structures on or above ground; (b) vegetation on or above the ground; or (c) other activity. [181]

The statute also requires specification in three-dimensional terms of the skyspace in which all obstructions are prohibited, and requires statement of any performance criteria for adequate collection at the particular location [182].

Just what constitutes an "order of taking" within the meaning of this law is unclear; is it an order pursuant to the power of eminent domain? A notable omission is failure to require the inclusion of specific conditions upon which the easement is to be granted or terminated. A further provision of the law requires the Energy Resources Commission to study "solar skyspace protection" [183].

Kansas has passed a law providing for the creation, recording, and content of solar easements that is quite similar in form to the prototype Colorado version [184]. The legislative history of the bill indicates that compensation provisions in the event of interference were considered but rejected, and that efforts failed to make the recording provision optional instead of mandatory [185].

Maryland considered but rejected the conventional approach of specification of the contents of a solar easement. Instead it passed a law in 1977 that simply designated the "reservation of exposure of solar energy devices" as a valid purpose of any restriction (easement, covenant, condition, etc.) on the use of land or water [186]. This concise 
language (exposure of a device) is identical to that used in the Colorado and Kansas statutes. Many passive solar applications that do not involve "devices" are left uncovered by the act.

Minnesota included a comprehensive section on solar energy in a 1978 law affecting most types of energy [187]. Solar easements are defined as a "right" in any form, expressed in any type of legal instrument, obtained for the purpose of "ensuring adequate exposure of a solar energy system ...." Recording and conveyancing laws are made applicable. An interesting variation is that the easement is permanent for both the properties burdened and benefitted, except when conditions of termination are expressly included in the document.

Minimal contents include a very flexible description of the easement, either in (1) traditional angles, (2) other methods of defining the three-dimensional space burdened, or (3) the place and times of day in which an obstruction to direct sunlight is prohibited or limited. Other provisions require inclusion of any terms of grant, termination, or compensation after obstruction or maintenance efforts. This law is the only one to explicitly allow the restriction to be enforced by injunctions, although this may not be of major significance since traditionally all easements have been enforced in equity. Another unique and beneficial provision is that depreciation caused by the burden of a solar easement may be reflected in reduced valuation and property taxes, but not appreciation to the dominant estate.

New Jersey passed a solar easement statute in 1978 which recognizes solar easements, and subjects them to the same legal requirements as other easements. The statute is typical of the Colorado-type laws in the descriptive information it requires [188].

North Dakota has adopted the Colorado approach virtually verbatim [189]. One difference, laudable for the sake of statutory clarity and grammatical completeness, is the inclusion of the following direct object: "exposure of a solar energy device to the direct rays of the sun." This is consistent with North Dakota's definition of solar energy devices, which does not include wind or water technologies.

Virginia also has followed the Colorado approach in its entirety [190]. In the legislative findings and intent section, which is lengthier than the easement section, the legislature expressed its desire to give "legal standing to solar easement agreements for the purpose of guaranteeing the exposure of solar energy equipment. . . to incident sunlight during the entire year." This encouragement of year-long access contrasts markedly with Illinois' semi-yearly approach.

\subsubsection{Covenants}

Restrictive covenants that cause an increase in the cost of a solar system, a decrease in its efficiency, or that preclude solar systems have been made unenforceable by the California legislature [191]. The statute declares all covenants, restrictions, or conditions in any deed, contract or security affecting the transfer or sale of, or any interest in, real property which "effectively prohibits or restricts the installation or use of a solar energy system" to be void. An exception is provided for "reasonable restrictions" which do not give rise to such barriers. The range of permissible restrictions is thus highly limited. Although retroactive applicability may seem a significant infringement upon private contractual freedom, and arguably a deprivation of property without "due process," it remains to be seen whether marketability of houses proximate to solar systems actually declines under this law. 


\subsubsection{Planning and Zoning}

Planning and zoning for solar access can work as a reinforcement to or substitute for express voluntary private agreements such as easements or covenants. Particularly in areas of new development, traditional zoning tools can ensure proper height and setback limitations and can mandate the use of restrictive covenants to adequately protect individual solar or wind access rights. Assessment of solar energy impacts could be required of all applicants for zoning variances, building construction, or remodeling permits.

Because many future solar applications will be in new buildings due to the large potential for passive design, conservation, and life-cycle costing, solar-conscious zoning and landuse planning are particularly important for growing states and localities. This promises to be a burgeoning area of solar law. The importance of solar energy in the context of zoning and planning laws is not yet reflected in the legislative activity by the states; only four states have addressed the issue, in contrast to the 12 which have confirmed and regulated the right to create private easements, covenants, or other agreements. Zoning and planning law changes are inherently more pervasive, destabilizing, and unpredictable in actual impact than are easement laws. The potential for zoning mistakes is as large as the promise of enlightened zoning. Knowledgeable legal scholars have thus prudently suggested that a "sharp scrutiny" be given to all such proposed solar access laws [192].

Connecticut passed a law in May 1978, allowing planning and zoning bodies to adopt regulations encouraging the use of solar energy and energy-efficient patterns of development [193]. This local prerogative approach is consistent with the local option property tax incentive authorized by the state. Authorized ways of implementing the state's pro-solar policy are merely listed in the following general categories: municipal zoning regulations; Planned Unit Developments (PUDs) and Transferable Development Rights (TDRs); local master development plans; subdivisions; and regional comprehensive plans.

Minnesota combined its 1978 property tax and solar easement provisions with planning and zoning legislation [194]. Paralleling the Connecticut approach, but in a more authoritative and detailed manner, the comprehensive law independently addresses each of the same planning devices as Connecticut, plus several others.

Local zoning boards in Minnesota are authorized to establish districts for the "protection and encouragement of access to direct sunlight for solar energy systems." Boards of adjustment may consider inability to use solar energy systems a hardship in the granting of variances. The zoning bodies are authorized to use traditional land-use controls (height, setback, bulk, size, lot percentage regulations, etc.) for the purpose of assuring "access to direct sunlight."

Suhdivision regulations arc allowed to serve the purpose of "protecting and assuring (sic) access to sunlight," and to use all of the previously mentioned land-use controls, plus restrictive covenants, to achicve that end. Regivilul planning commissions are to address the access issue in comprehensive development planning. The actual plans may include "methods for protection and assuring access to direct sunlight." Local land-use plans must include an "element for protection and development of access."

Oregon was the first state to comprehensively address solar access in the context of planning and zoning laws. The 1975 statute adds "incident solar energy and utilization" to the mandatory considerations required for all comprehensive plans, zoning, and sub- 
division ordinances and regulations [195]. County planning commissions may recommend to county governing bodies ordinances "protecting and assuring access to incident solar energy," including height and setback limits. City planning commissions are authorized to suggest plans including "appropriate public incentives for overall energy conservation." City councils are granted authority to regulate setbacks, a power they did not expressly possess before. The setback regulations "may also consider site slope and tree cover, with regard to solar exposure."

A further proviso provides that "the council shall not unreasonably restrict constiuction where site slope and tree cover make incident solar energy collection unfeasible, except an existing solar structure's sun plane shall not be substantially impaired." This section commendably recognizes that natural conditions (slope and vegetation) can influence the proper placement of a solar structure, which in turn could cause violation of height, setback, or bulk controls. Where it is simply not feasible for a new building to be oriented for solar energy, solar-inspired zoning controls may be inapplicable. But, the new building may not infringe on a northern neighbor's solar uccess even if it will not be benefited by or oriented in accord with the zoning controls. Such infringement could otherwise easily occur on a north sloping hill. The force of this consideration is emphasized by a last provision, to the effect that "the powers given in this section shall be exercised so as to preserve constitutional rights," presumably a reference to property rights which may be infringed or "taken" when zoning operates in a discriminatory or confiscatory manner.

California also addressed planning and zoning concerns in its Solar Rights Act of 1978 [196]. Subdivision design must now reflect future passive or natural heating or cooling opportunities on required maps. Examples include allowance for southern exposure, or lot configurations that can exploit shade and prevailing breezes. Local climate, contour, and lot configurations are factors to be considered. Limitations on the subdivision design begin with feasibility, defined to include successful accomplishment in a timely manner taking into account economic, environmental, social, and technological factors. Other limitations include the proviso that the design not cuuse a reduction in allowable densities or building area. Conversion of buildings to condominlums is exempted from the law's application.

A unique provision in the California law allows localitles to require, as a condition of approval of a subdivision design, the "dedication" of solar easements for each lot by the lot to the south. The developer has always had this option under common law, and could achieve the same result by creating sulur cuvenants beforc oolo. The locality cnuld also reach this end by proper zoning of subdivisions. Since the "dedicator" may not also be required to install solar systems, this provislon uppear's anticipatory. Yot the actual cost to the developers of such a preliminary action will probably be less than the aggregate cost of individual transactions creating easements.

\subsubsection{Public Nuisance}

A legislative declaration of certain types of interference with solar access as a public nuisance is a viable solution to many access problems. California has taken the initiative in this area by dealing with one aspect of the problem, that of shade control [197]. Recognizing that shade trees and shrubs can have beneficial effects upon energy conservation, the law nonetheless provides for protection of existing solar collectors from new or subsequent shading of more than $10 \%$ of its absorption surface area between 10 a.m. and 2 p.m. The law applies to active or passive collectors, and to thermal or electrical applications. 
The protected collector must be located over $5 \mathrm{ft}$ from the property boundary, and must be elevated by $10 \mathrm{ft}$, although lowering is permitted if the setback is correspondingly increased 3 times. In other words, a ground-level collector must be $(3 \times 10+5) \mathrm{ft}$, or at least $35 \mathrm{ft}$ from the neighbor's land. More significantly, a county or city can opt out of the state's statutory jurisdiction. After 30 days notice of a complaint, the prosecutor is required to enforce the act, which provides that separate violations for each day of illegal shading are punishable by a fine of up to $\$ 500$. Defendants can include the owner, lessee, or other person maintaining the tree. A remarkable provision allows someone who plans a "passive or natural system," which presumably incorporates shade trees, to seek a special exemption in court. Why the exception should be judicially granted is unclear. Also, trees grown as commercial crops and trees planted as replacements for previously existing trees are exempt. The court would assert its equitable power to grant an exception only upon a showing that the tree would provide a "greater net energy savings than the active system" to be impacted.

The California measure is a laudable attempt to ensure real energy savings instead of merely promoting the latest technology. There are fears that public nuisance measures won't be effective unless applied retroactively, which would upset private planning. Yet the small number of existing solar installations indicates that this concern may be insignificant at present, whatever its long-term effects. One criticism is that this period of immunity should be longer for previously growing trees. However, this possible loss of future growth must be balanced against the reliance on future access by the collector owner and the financial and energy investment represented in the system. Another potential problem is the rigidity of the setback requirement, which may be unrealistic for collectors situated on land with steep slopes.

\subsubsection{Solar Rights by Analogy to Water Law}

New Mexico's novel approach to solar access [198], based on an analogy to western water law [199], declares property rights in sunlight that may be appropriated on a first-come, first-served basis. The Solar Rights Act defines the property right as "an unobstructed line-of-sight path from a solar collector to the sun, which permits radiation from the sun to impinge directly on the solar collector." Disputes are to be resolved by applying the water law concepts of beneficial use and prior appropriation.

Beneficial use is declared the "measure and the limit" of the solar right, which may vary seasonally. The solar right is created by the intent to appropriate actual use of sunlight, and "priority in time shall have the better right" in disputes. The state and political subdivisions may further declare the right if a proposed collector site is blocked from the sun.

The statute is clearly controversial, and has been criticized by some legal scholars [200] as unconstitutional, impractical, and containing inconsistent and unnecessary provisions based on fallacious assumptions concerning water law. These weighty objections will be explained briefly. First, the permit system might become unmanageable if too many landowners applied, especially if conditional decrees pending future beneficial use were granted (as is possible in the water laws). But similar criticisms may apply to programs of state certification of solar devices or tax exemptions requiring individual application.

Second, the Act may be inconsistent. It purports to promote the use of solar energy primarily for economic benefits, when the practical result of the Act could be interpreted to allow, for example, a small collector at the base of a north-facing hill to block 
a large and valuable construction project to the south along the top of the hill. The easy answer is that the solar right could then be purchased, though possibly at an exorbitant price, assuming that the solar right owner chooses to sell.

Third, a resultant drop in the values of "up-sun" (cf. upstream) lands might violate the due process and equal protection clauses of the United States Constitution. The scheme could be construed as a taking without compensation instead of a valid regulation, if the diminution in value is great enough, and if alternative uses are nonexistent. Fourth, the provision protecting "existing" solar rights from the impact of the Act appears unnecessary, for a situation where one collector would shade another collector on separate land is virtually nonexistant.

Why distinguish between citizens on the basis of prior appropriation when sunlight is not that scarce? Unless conditional decrees for future use are granted, a premature rush to erect collectors of any type, or struciluiress that are designed to preempl un eusentul might ensue. Finally, the choice of water law analogies is based on the renewability of sun and water. However, the entire existence and need for the prior appropriation water system is based on scarcity of water and diversion (consumption). The riparlan rights model which compares the reasonableness of competing uses might be a more costeffective system in the case of solar rights.

In effect, the New Mexico system recognizes a solar easement based on prior, though possibly short-lived use of sunlight, thus going far beyond the period for prescriptive easements (10-20 yrs) and the Doctrine of Ancient Lights, both of which have been rejected in most states. An instant or even prospective right to light is purportedly created. In the time required to properly assess the administration of the system, a court case testing the constitutionality of the statute will probably be brought by a preempted developer. Even if the statute survives such a test, it is evident, in the words of the authors of the Environmental Law Institute (ELI) study, "a simpler, more certain, and more equitable approach is necessary" [201]. 


\section{SECTION 7.0}

\section{UTILITIES}

The relationship between utilities and use of solar technology presents complex and controversial issues which will only be outlined below. Three major issues are public utility commission (PUC) jurisdiction, utility activity, and discriminatory rate making. Only seven states have directly legislated in this area, though PUCs are confronting similar issues in rule-making proceedings at a less conspicuous but more widespread level. The most significant single event in this area has been the passage of the National Energy Act.

\subsection{PUC JURISDICTION}

The issue of PUC jurisdiction concerns the propriety and extent of state regulation of solar energy technologies. Industrial and decentralized community solar installations of ten involve sharing or selling of power. If an apartment building has a shared solar system, is the building owner a "utility" impressed with a "public interest"? Should such applications be controlled by PUC licensing, a process that involves lengthy hearings on site selection, rate making, and territorial jurisdiction?

Hawaii has decided generally to exempt from PUC jurisdiction and regulation facilities which produce, transmit, or furnish power produced primarily from "non-fossil fuel sources for its internal uses," although excess power must be purchased by local utilities, at rates to be arbitrated by the PUC-if necessary [202]. The Hawaii legislature expressly intended to aid the state's sizeable sugar industry by allowing it to burn its waste product (bagasse) in an unrestricted manner. By allowing unrestricted competition in power production for the sugar industry, the evolution of bioconversion technology may be hastened.

California passed a 1978 law establishing the basis of PUC regulation of public utilities' involvement with solar energy development [203]. The legislative purpose was to "ensure that the solar energy industry develops in a manner which is competitive and free from the potential dominance of regulated electrical and gas corporations." Utilities are required to apply for permission to "manufacture, lease, sell, or otherwise own or control any solar energy system" not used for experimental or demonstration purposes. Authorization is expressly contingent upon a PUC finding that competition and growth in the solar energy industry will not thereby be restricted, and that development and use of solar in the state will be accelerated by the program.

\subsection{UTILITY ACTIVITY}

The range of possible utility involvement with solar energy is the subject of intense debate. Some see solar energy as a means of gaining independence from utilities, and resist utility involvement. Others welcome utility participation in solar development. This question is the direct subject of legislation in five states. Arkansas has authorized its PUC to allow utilities to invest in, service, and charge for energy conservation programs that are defined to include solar energy [204]. Among the eligible technologies are "wind power, geothermal energy, biomass conversion, or the energy available from municipal, silvicultural, or agricultural wastes." 
Illinois has also allowed existing utilities to participate in fostering the use of solar energy [205]. The "funding and provision" of solar systems has been declared to be a "valid service and purpose" of a utility within its service area, with the proviso that these activities shall not constitute a monopoly.

Montana has chosen to go beyond mere authorization of utility involvement, and has provided positive incentives for direct activity [206]. The law now permits utilities to extend credit to customers for solar installations in return for compensating increases in service charges and new credits on the utility license tax [207].

Calif ornia has also provided some incentive for utility investment in renewable energy sources [208]. A 1976 law allows the PUC to authorize rates of return of $0.5 \%$ higher than normal for investments in solar, geothermal, and hydroelectric resources. The renewable energy resource must have a lower cost per unit of energy over the system's life than do conventional sources.

Kansas allows a similar rate-making incentive to encourage investment in solar, geothermal, wind, or biomass energy technologies [209]. The rates can be increased from 0.5-2\%, but only for applications for commercial purposes.

\subsection{DISCRIMINATORY RATES}

Arkansas, California, and Montana justify utility involvement on the theory that longterm growth of peak capacity requirements and demand load can be attenuated by promotion of solar and conservation technologies, reducing long-term capital costs and rate increases. However, fears have been expressed by the utility industry that intermittent use of backup electrical energy by solar users may occur at cold or cloudy periods when peak generating load is greatest. In most states, health, property, or building codes unnecessarily require full-scale residential backup systems, as do the HUD Minimum Property Standards. The result is a large potential use of conventional energy by solar users. Some utilities are concerned that widespread use of solar devices could contribute to peak load management problems, requiring increased capacity above lower levels of flucturting demand.

Since new plants are the costliest, it is argued that rates reflecting the cost of new service should be higher for solar customers. Also, since solar customers would use less total energy while still requiring a full demand load, the cost of delivery of energy would be higher per unit. The concern with "discriminatory" rate making against solar customers by utilities is thus quite real.

The conflict over the role of utilities in solar commercialization may be mitigated by three developments. One is the improvement and development of passive and conservation technologies, including the energy storage devices that accompany most active SHACOB systems, which would reduce peak load management problems. Expanded rock, liquid, or chemical storage capacity could be assisted by electrical or natural gas backup heating at off-peak periods.

Another development is the rise in the number of municipal utilities that do not operate under a profit motive. Private utilities pay dividends to taxpayers and charge rates that are partially based on their amount of capital and capital construction. Apart from conservation legislation, only if peak demand growth exceeds generating capacity increases do private utilities have a real incentive to reduce absolute demand. Municipal 
utilities do not share the same built-in growth incentive as profit-making utilities, although sometimes municipal utility revenues subsidize other city programs. They generally require lower rates of return and can be expected to be less hostile toward solar users. The third development is the rise of legislation forbidding discriminatory rates charged against solar users.

Illinois has recently passed such antidiscriminatory rate legislation [210]. A general statutory ban on preferential or prejudicial rates was amended to prohibit the charging of higher service or commodity (electricity or gas) rates to any customer using solar energy. The law will expire five years after its enactment in 1977. At the same time, Illinois passed a Comprehensive Solar Energy Act directing the Energy Resources Commission and the Illinois Commerce Commission to study the relationship of public energy supplies to solar energy. The study will encompass (1) rate schedules that encourage the use of solar energy and help provide supplemental energy, and (2) power plant site selection criteria that include the potential of solar use in load forecasts. A separate study will assess regulatory and enforcement mechanisms for joint solar energy systems and utility deployment of solar systems [211].

Iowa has prohibited municipal, corporate, or cooperative electric or gas utilities from making "discriminatory rates or charges" or otherwise causing "prejudice or disadvantage" to a user of renewable energy sources [213].

\subsection{NATIONAL ENERGY ACT}

The National Energy Act includes several provisions affecting utilities, specifically incorporated in the Public Utility Regulatory Policies Act of 1978 [214]. Utilities are encouraged, through state energy agencies or PUCs, to implement energy conservation programs for existing residential buildings, including installation of solar and wind power devices [215]. Rate structures are to be redesigned in order to encourage efficient use of energy, including nondiscriminatory rates for small power production facilities [216]. These measures may mean that there will be less incentive for similar legislation at the state level, and may cause and fund extensive readjustments in the administrative regulations and policies of most PUCs [217]. 
SEPl 


\section{SECTION 8.0}

\section{REFERENCES}

1. U.S. Const. amend. X. Federal elements in the national government, such as electoral representation and the existence of concurrent state judicial jurisdiction, are additional examples of the fundamental role of the states in the constitutional framework of the United States.

2. Major federal laws include:

Solar Heating and Cooling Demonstration Act, Pub. L. No. 93-409, Sept. 3, 1974, 42 U.S.C. $\$ \$ 5501$ et seq.

Solar Energy Research Development and Demonstration Act, Pub. L. No. 93-473, Oct. 26, 1974, 42 U.S.C. $\$ \$ 5551$ et seq.

Federal Nonnuclear Energy Research and Development Act, Pub. L. No. 93-577, Dec. 1974,42 U.S.C. $\$ \$ 5901$ et seq.

3. U.S. Dept. of Commerce, Intermediate Minimum Property Standards for Solar Heating and Domestic Hot Water Systems. Washington, D.C.; March 1977; NBSIR 77-1226 (unpublished). Authorized under 42 U.S.C. $\$ 3535$ (d), 12 U.S.C. $\$ 17516,5$ U.S.C. $\$ 552(a) ; 24$ C.F.R. $\$ 200.929(6)(4)$; (incorporated by reference); amended in 42 Fed. Reg. 33898 (July 1, 1977).

See also U.S. Dept. of Commerce, National Bureau of Standards, Intermediate Minimum Property Standards Supplement: Solar Heating and Domestic Hot Water Systems, Vol. 5 (supersedes NBSIR 77-1226). Washington, D.C.: U.S. Dept. of Housing and Urban Development; 1977. Avail. GPO, SD Catalog No. 4930.2; U.S. Dept. of Commerce, National Bureau of Standards, Intermediate Standards for Solar Domestic Hot Water Systems/HUD Initiative. Washington, D.C.: National Bureau of Standards; 1977; NBSIR 77-1272. Avail. NTIS, PB 271758.

4. Harris Survey reports that Americans favor expansion of solar energy use by 94 to $2 \%$, the highest priority granted to any energy source. Quoted in Solar Energy Intelligence Report, Vol. 4 No. 24, 6/12/78, at 175 .

5. See especially The Energy Tax Act of 1978, Pub. L. No. 95-618, 92 Stat. 3174, in Congressional Index No. 97, Nov. 16, 1978.

6. John Ashworth, Bruce Green, et al. have prepared a limited case study on the administration of state legislation in selected states. See "The Implementation of State Solar Incentives: A Preliminary Assessment," Analysis and Assessment, Solar Energy Research Institute, Jan. 1979. This author agrees that "[ $t]$ he implementation process is an important determinant of the final form and of the effectiveness of a state incentive for solar energy. Implementation is particularly important for determining which technologies and components are eligible for an incentive ...." Id. at 1. See also Warren, "Common Problems in Drafting State Solar Legislation," l Solar L. R. 157 (1979). 
7. B. W. Cone, D. L. Brenchley, V. L. Brix, et al., An Analysis of Federal Incentives Used to Stimulate Energy Production: An Executive Summary. Richland, WA: Battelle Pacific Northwest Laboratories; March, 1978; PNL-2410. p. 276. Avail. NTIS.

8. S.J.R. No. 53, 1977 Texas Gen. Laws, amending Tex. Const. art. VII, $\$ 2(a)$; Ch. 354, 1977, Fla. Gen. Laws, amending Fla. Const. art. 7, $\$ 4(b)(3)$, codified at Fla. Stat. $\$ 193.622$ (Supp. 1978).

9. E.g., Tex. Const. art. VIII, $\$ 2(a)$.

10. S. R. 284, Res. 167, Ch. 1465, 1976 Ga. Laws. Passage amended Ga. Const. art. VII, $\$ 1$, Par. IV.

11. California Proposition 3, June 6, 1978; Senate Const. Amend. No. 15, 1977; Ch. 103,1977 Cal. Stats.

12. Ch. 323,1978 Neb. Laws.

13. Ch. 59l, 1978 La. Acts; to be codified at La. Rev. Stat. Ann. $\$ 47-1706$.

14. Ch. 548, 1975 Mont. Laws, repealed by Ch. 576, 1977 Mont. laws; to be codified at Mont. Rev. Codes Ann. \$ 84-7403.

15. Ch. 322, \$ 1, 1977 N.Y. Laws; N.Y. Real Prop. Tax Law $\$ 487$ (Supp. 1977).

16. William A. Thomas, A. Miller, and Robbins, Overcoming Legal Uncertainties About Use of Solar Energy Systems, Chicago: American Bar Foundation; 1978; pp. 75-76 [hereinaf ter cited as Thomas].

17. N.H. Rev. Stat. Ann. \$\$ 72:61-68, I (Supp. 1977).

18. See tax and loan tables (Tables 2-1 and 3-1) in this article.

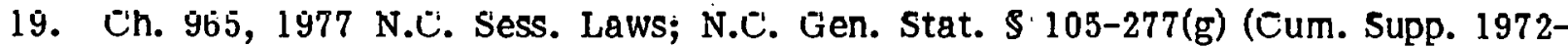
1977).

20. E.g., Cal. Rev. \& Tax Code $\$ 17052.5$ (West Cum. Supp. 1977-1978).

21. Ch. 256, $\$ 11977$ Laws of New Jersey; N.J. Rev. Stat. $\$ \$ 54: 4-3.113$ (West Supp. 1977).

22. The Harold Hay roof pond is in essence a large bag of water perched on the roof of a structure. During the day it blocks sunlight and absorbs heat, cooling the house. At night it is insulated by a top-cover (a semi-passive feature) and radiates heat into the house below.

The Tromé wall is a French invention using windows which allow exposure of a darkened heavy cinder block or concrete wall to the sunlight. A vent system allows air, heated by the wall, to circulate throughout the structure when desired. See also D. L. Buchanan, Solar Energy Research Institute, Program Evaluation Branch, Annual Review of Solar Energy. Golden, CO: SERI; Nov., 1978; SERI/TR-54-066, pp. 81-82. Avail.: NTIS. 
23. 42 U.S.C. $\$ \$ 5502.1-.2,5506$ (1977).

24. Ch. 345, $\$ 1,1977$ Nev. Stats.; Nev. Rev. Stat. $\$ 361.795(1)$ (1977).

25. Ch. 591, 1978 La. Sess. Laws; to be codified at $\$ 47-1706$.

26. Thomas, note 16 supra.

27. Ch. 135, $\$ 4,1976$ Mich. Pub. Acts; Mich. Stats. Ann. $\$ 7.7(4 e)(11)$ (Callaghan 1978).

28. Ch. 68, 1977 Ind. Acts; amending Ch. 15, 1974 Ind. Acts; Ind. Code \$ 6-1.1-12-27 (1977).

29. For example, Maine exempts solar energy equipment, without reference to where it is located. See Ch. 542, 1977 Me. Acts; Me. Rev. Stat. Ann. $\$ 656$ (1) H (West Cum. Supp. 1964-1978).

30. Ch. 74, $\$ 8,1978$ S.C. Sess. Laws; S.D. Comp. Laws Ann. $\$ 10-6-35.8$.

31. Ch. 111,1975 S.D. Sess. Laws.

32. See text accompanying notes 8 through 16 , supra.

33. Ch. 196, 1977 Or. Laws; Or. Rev. Stat. $\$ 307.175$ (1977).

34. Ch. 409, $\$ 2,1976$ Conn. Pub. Acts, as amended by Ch. 490, 1977 Conn. Pub. Acts; Conn. Gen. Stat. Ann. $\$ \$ 12-81(56-57)$ (West Cum. Supp. 1972-1977).

35. N.H. Rev. Stat. Ann. $\$ 72: 61-68$, I (Supp. 1977).

36. Ch. 388, 1978 Sess. Laws, Mass. Ann. Laws, Ch. 9 , $\$ 5$.

37. Chl. 740, 19'/b Md. Laws; Md. Ann. Code (1975) art. 81, $\$ 12-F(5)$ (Michie Cum. Supp. 1975-1977).

38. Ch. 74, $\$ 6,1978$ S.D. Sess. Laws; S.D. Comp. Laws Ann. $\$ \S 10-6-35.8$ to -35.18 (Supp. 1978).

39. Ch. 345,1977 Nev. Stats., to be codified at $\$ 199.120(3)$.

40. Thomas, note 22 supra, at 79 .

41. 51 Am. J. 1st Tax $\$ 26$, (Americen .Jurisprudence).

42. 31 Am. J. 2d Exemp $\$ \$ 1,2$.

43. This is listed in Table 2-1 as Formula 2. See Ch. 618, 1977 N.Y. Laws, amending Ch. 322, 1977 N.Y. Laws; N.Y. Real Prop. Tax Law $\$ 487$ (Supp. 1978).

44. Ch. 202, 1977 R.I. Pub. Laws; R.I. Gen. Laws \$ 44-3-19 (Cum. Supp. 1970-1977). 
45. Ch. 344, 1975 Colo. Sess. Laws; Colo. Rev. Stat. $\$ 39-1-104$ (Cum. Supp. 19731976).

46. Ch. 345, $\$ 1,1977$ Kansas Sess. Laws; Kan. Stat. Ann. $\$ 79$ (a)(01-02) (1977).

47. Ch. $74, \S 6,1978$ S.D. Sess. Laws; S.D. Comp. Laws Ann. $\$ 10-6-35.8$ to 35.18 (Supp. 1978).

48. Id.

49. See note 5 , supra.

50. E.g., Ch. 487, 1976 Mass. Laws; Mass. Ann. Laws Ch. $63 \$ 38 \mathrm{H}$ (Michie/Law Co-op 1978).

51.. Rnoz, Allen and Hamilton, "Solar Energy Utilization in Florida," cited in Solar Energy Commercialization at the State Level: The Florldu Bului Energy Watcr Heater Program, Florida Solar Energy Center, March, 1977; FEA/G-77/270. p. 24. Avail.: NTIS; PB 270158.

52. Ark. Stat. Ann. $\$ 84-2016.8$ (Cum. Supp. 1960-1977).

53. Cal. Rev. \& Tax. Code $\$ 17052.5(4)$ (West Cum. Supp. 1977-1978).

54. N.M. Stat. Ann. \$ 72-15A-11.3 - 11.4 (Cum. Supp. 1953-1977); Cal. Rev. \& Tax Code $\$ 234$ (West. Supp. 1970-1977).

55. N.C. Gen. Stat. $\$ \$ 105-151.2$ (Cum. Supp. 1962-1977).

56. Or. Rev. Stat. $\$ 316$ (1977).

57. Alaska Stat. $\$ 43.20 .039(c)$.

58. N.M. Stat.' Ann. \$ 72-15A - 11.3 (Supp. 1975).

59. Ch. 1082, 1977 Cal. Stats., amending Ch. 168, 1976 Cal. Stats.

60. See Ch. 1159, 1978 Cal. Stats.; Cal. Rev. \& Tax Code $\$ 1 \% u 5 \% .5$ (West CuII. Supp̈. 1977-1978).

61. A figure of $\$ 1,700$ for $84 \mathrm{ft}^{2}$ feet of double glazed collector area with liquid storage and gas or electric backup (1977 dollars) is estimated in Flaim, Silvio J. et al., Economic Feasibility and Market Readiness of Eight Solar Technologies, Interim Draft Report, June, 1978. SERI-34. p. 28.

62. Ch. $1082, \$ 4,1977$ Cal. Stats.

63. Ch. 209, $§ 3,1977$ Okla. Sess. Laws; Okl. Stat. Ann. tit. 68 2357.3.

64. Ch. $1082, \S 5,1977$ Cal. Stats.

65. Ch. 81, \$ 6, 1977 Ariz. Sess. Laws; Ariz. Rev. Stat. $\$ 42-123.01$ (Supp. 1957-1978). 
66. Kan. Stat. Ann. $\$ 79-32-168$ (1977).

67. N.M. Stat. Ann. $\$ \$ 72-15 A-11.3(F)$ to $-11.4(G)$ (Supp. 1975).

68. Wisc. Stat. Ann. $\$ 71.09(12)(b)$ (West Cum. Supp. 1969-1977).

69. Testimony of Sheldon Butt, President, Solar Energy Industries Assoc.; Joint Hearing Before the Subcommittee on Energy Production and Supply, Subcommittee on Energy Research and Development of the Committee on Energy and National Resources, and the Select Committee on Small Business, U.S. Senate, Golden, Colorado, June 1, 1977, 95 th Cong., Ist Sess.

70. Thomas, note 16 supra, at 80 .

71. Alaska Stat. Ann. $\$ 43.20 .038(a)(b)(1977)$.

72. Ariz. Rev. Stat. $\$ 43-128.03(a)-(c)$ (Cum. Supp. 1957-1978).

73. Id. $\$ 43-128.04$.

74. Ch. 93, 1975 Ariz. Sess. Laws, amended by Ch. 129, 1976 Ariz. Sess. Laws; Ariz. Rev. Stat. 43-123.37 (1957-1978).

75. Ariz. Rev. Stat. $\$ 43-123.37$ (Supp. 1977).

76. Ark. Stat. Ann. \$ 84-2016.8-.10 (Supp. 1977).

77. Colo. Rev. Stat. $\$ \$ 39-22-113(4)(c)($ I)-(III) (Supp. 1977).

78. Id. $§ 39-22-112)$.

79. Id. $\$ 39-22-304(3)$.

80. Mass. Ann. Laws. Ch. 63, $\$ 38 \mathrm{H}(\mathrm{b})(1)$ (Michie/Law Co-op 1978).

81. Cal. Rev. \& Tax Code $\$ 17052.5$ (West Cum. Supp. 1977-1978).

82. Ch. 168, 1976 Cal. Stats., amended by Ch. 1082, 1977 Cal. Stats., amended by Ch. 1159,1978 Cal. Stats.; Cal. Rev. \& Tax Code $\$ 1705 \% .5$.

83. Ch. 1154, 1978 Cal. Stats.; Cal. Civ. Code $\$ \$ 801,-.5$ (West Cum. Supp. 19771978).

84. Haw. Rev. Stat. $\$ 235-12$ (1976).

85. Idaho Code $\$ 63-3022 C$ (Supp. 1978).

86. Kan. Stat. Ann. $\$ \$ 79-32-166-67$ (1977).

87. N.M. Stat. Ann. \$\$ 72-15A-11.2-11.4 (Cum. Supp. 1953-1977).

88. N.C. Gen. Stat. $\$ \$ 105-130.23,151.2$ (Cum Supp. 1962-1977). 
89. Or. Rev. Stat. $\$ \$ 469.160-.180,316.116$ (1977).

90. Promulgated pursuant to Pub. L. No. 93-409, Solar Heating and Cooling Demonstration Act of 1974, 42 U.S.C.A. $\$ 5506$.

91. Ch. 576, 1977 Mont. Laws (deductions); Ch. 574, 1977 Mont. Laws (credits); Mont. Rev. Codes Ann. \$\$84-7403 (deductions), 84-7414 (credits) (Cum. Supp. 19471977).

92. Mont. Rev. Codes Ann. \$ 84-7401 (Cum. Supp. 1947-1977).

93. Id. $\$ 84-7414$.

94. Id. $\$ 84-7402$.

95. N,D, Cent. Code $\$ 57-38-01.8$ (Supp. 1977).

96. R. G. Jones, H. M. Sramék, J. M. Pelstel, Analysiz of Stato Solar Energy Pnlicy Options. Washington, D.C.: National Conference of State Legislatures; June 1976, p. I-1, Avail.: NTIS PB-254 730.

97. Okla. Stat. Ann. tit. $68 \$ 2357.1-.2$ (West Cum. Supp. 1971-1977).

98. Ch. 209, 1977 Okla. Sess. Laws.

99. The Energy Tax Act of 1978, Pub. L. No. 95-618, $\$ 101,92$ Stat. 3174 in Cong. Index No. 97, Nov. 16, 1978. Amending the Internal Revenue Code of $19 \overline{54 \text { by }}$ adding Code Sec. $44 \mathrm{c}$.

100. Cal. Rev. \& Tax. Code $\$ \$ 17052.5(\mathrm{j}), 2360 \mathrm{l}(\mathrm{h})$ (West Cum. Supp. 1975-1977).

101. N.M. Stat. Ann. $\$ 72-15 A-11.3(c),-11.4(D)$ (West Cum. Supp. 1953-1977).

102. Mont. Rev. Codes Ann. $\$ 84-7414$ (1) (Cum. Supp. 1947-1977).

103. Except insofar as the license (franchise) taxes are enacted pursuant to the police power in addition to the taxing power. 71 Am. J. 2d, State and Iocal Taxation $\$ \$$ 28-30.

104. Id. at $\$ 163$.

105. 68 Am. Jur. 2d, Sales and Use Taxes 177, $\$ 129$.

106. Id. at $190, \S 135$.

107. 71 Am. Jur. 2d, State and Local Taxation at 583, $\$ 266$.

108. Ariz. Rev. Stat. $\$ 42-1312.01(A)(9)$ (Cum. Supp. 1957-1978).

109. Id. $\$ 42-1409(B)(9)$ (Cum. Supp. 1957-1977).

110. Conn. Gen. Stat. Ann. $\$ 12-412$ (dd) (West Cum. Supp. 1974-1978). 
111. Id. \$ 12-81(56) (West Cum. Supp. 1974-1978).

112. Ch. 1030, Ga. Laws of 1976, amended by Ch. 1309, $\$ 1$, Ga. Laws of 1978; to be codified at $\$ 92-3403 a(c)(2)(b b .2)$.

113. Me. Rev. Stat. tit. 36, § 1760(37) (1977).

114. Mass. Ann. Laws. Ch. 64H, $\$ 6$ (dd) (Michie/Law Co-op 1978).

115. Mich. Stat. Ann. $\$ 7.525(8)$ (sales), $\$ 7.555(4 \mathrm{e})$ (use).

116. N.J. Stat. Ann. $\$ 54: 32 B-8(f f)$ (West Supp. 1978-1979).

117. Tex. Tax. Gen. Code Ann. tit. 122A, $\$ 12.03(1)(r)$ (Vernon Supp. 1978).

118. Income tax provisions for depreciation or amortization are functionally similar to loans in that the taxpayer defers the tax and keeps the money longer than otherwise possible.

119. Ch. 1154, 1978 Alaska Sess. Laws; Alaska Stat. $\$ \$ 45.88 .010-.040$ (1978).

120. Ch. 1, 1978 Cal. Stats.; to be codified at Cal. Health \& Safety Code $\$ \$ 41260-65$, 50680-85.

121. Ch. $1, \S 8,1978$ Cal. Stats.

122. Ch. 264, 1976 Cal. Stats; Cal. Pub. Res. Code $\$ 25410$ (West Cum. Supp. 19631978).

123. Ch. 1243,1978 Cal. Stats; Cal. Mil. \& Vet. Code $\$ \$ 987.64,987.92$ (West Cum. Supp. 1955-1977).

124. Iowa Code $\$ 220.1-.12$.

125. Mass. Ann. Laws. Ch. $168, \S 168, \S 35(10)$ (banks); Ch. 170, $\$ 26(6)$ (co-operative banks); Ch. 171, $\$ 24(D)$ (credit unions); Ch. 172, $\$ 55$ (trust companies) (Michie/ Law Conn Supp. 1977).

126. Ch. 73, 1978 Mass. Laws; amending Mass. Ann. Laws ch. $168 \$ 35(10)$ (Michie/Law Co-op Supp. 1978).

127. Minn. Stat. Ann. $\$ 462$ A.05(14-15) (West Cum. Supp. 1963-1978).

128. Id. $\$ 462$ A.22 (West Cum. Supp. 1963-1978).

129. Mont. Rev. Codes Ann. \$ 84-7405(1)-(2) (Cum. Supp. 1947-1977).

130. Id. $\$ 84-7402(3)$.

131. Or. Rev. Stat. $\$ 407.048$ (1977).

132. S.J.R. 32, 1977 Or. Laws, amending Or. Const. art. XI-D. 
133. Ch. $732, \S 6,1977$ Or. Laws (uncodified).

134. Ch. 732, $\$ 21977$ Or. Laws (uncodified) (emphasis added).

135. Tenn. Code Ann. $\$ \$ 13-2303$ (19), -2315 (29), new section, (Cum. Supp. 1973-1977).

136. Id. $\$ 13-2316(a)-(d)$.

137. See Pub. L. No. 95-315, 92 Stat. 377 (1978); Pub. L. No. 95-476, 92 Stat. 1497 (1978); Pub. L. No. 95-113, 91 Stat. 996 (1977); Pub. L. No. 95-619, 92 Stat. 3235 (1978).

138. National. Energy Conservation Policy Act of 1978, Pub. L. 95-619.

139. Tom Hill of the Florida Solar Energy Center estimated the cost of warranty compliance (including performance standard6) for hot water systems at about \$30$\$ 40$. A. Wallenstein of the North East Solar Energy Center reported industry cost estimates of $\$ 300$ per space heating collector for performance standards compliance, which would substantially decrease the efficacy of such tax-related regulations. However, the standards could be a demand-stimulator. The latter information is derived from a meeting with SERI interns in the summer of 1978:

140. See note 3 , supra.

141. Interim Performance Criteria for Solar Heating and Combined Heating/Cooling Systems and Dwellings, Washington, D.C.: Dept. of Housing and Urban Development. Promulgated pursuant to the Solar Heating and Cooling Demonstration Act of 1974, 42 U.S.C. \$5506. See also U.S. Depl. of Commerce, National Bureau of Standards, Solar 'l'echnology Progr'ull. Interim Performance Criteria for Solar Heating and Cooling Systems in Kesidential Buildings. $2 \mathrm{~d}$ ed. Washington, D.C.: National Bureau of Standards; November, 1978; NBSIR 78-1562.

142. In contrast to income tax related standards, property tax related standards could create greater problems of (intra-state) uniformity because the property tax is locally assessed, allowing substantial local discretion as to what standards are adopted, and what systems must comply. Note, e.g., Maryland's property tax exemption authorizing localities to determine which systems are eligible. Note Virginia's property tax related certification program, in which the State Board of Housing is authorized to promulgate regulations setting forth criteria for certifiable solar energy equipment. (See also Table 2-1).

143. The National Solar Heating and Cooling Information Center (NSHCIC) lists these five states in this category. The NSHCIC is a good source of current information on solar legislation. Toll free telephone: (800) 523-2929. See note 3 to Appendix A.

144. $\$ 7$, Ch. 1081,1977 Cal. Stats.; Cal. Pub. Res. Code $\$ \$ 25600,25605$ (West Supp. 1977).

145. $\$ 2$, Ch. 409, $\$ 2$, Conn. Pub. Acts of 1976; Conn. Gen. Stat. Ann. $\$ 16 a-14(8)$ (West Supp. 1978).

146. Ch. 246, 1976 Fla. Laws; Fla. Stat. Ann. $\$ 377.705(1)-(4)$ (Supp. 1978). 
147. Ch. 309, $\$ 1,1978$ Fla. Laws; Fla. Stat. Ann. $\$ 377.705(4)(d)$ (Supp. 1978).

148. Ch. 333, $\$ 14,1976$ Minn. Laws.; Minn. Stat. Ann. $\$ 116$ H.127 (West Supp. 1978).

149. Ch. $347, \S 1(B)(1)-(2), 1977$ N.M. Laws; to be codified in N.M. Stat. Ann. $\$ 73-26-5$.

150. U.C.C. $\$ 2-315$.

151. Id. \$ 2-314.

152. Id. $\$ 2-313$.

153. 15 U.S.C. $\$ 2301$ et. seq.

154. R. Vories, Solar Warranties Workshop: A Summary, Golden, CO: Solar Energy Research Institute, August 1978. SERI TP-62-046. Avail.: NTIS.

155. Ch. 649,1978 N.Y. Laws; to be codified at N.Y. Energy Law \$S 12-101 to 12-114.

156. See C. G. Field, S. R. Rivkin, The Building Code Burden. Lexington, MA: Lexington Books, Mass., 1975; and Meeker, "Building Codes as Barriers to Solar Heating and Cooling of Buildings," Environmental Law Institute, Wash, D.C., 1978, [hereinaf ter cited as ELI Study].

157. Ch. 670, $\$ 1,1976$ Cal. Stats.; Cal. Health \& Safety Code $\$ 17959$ (West Supp. 1978).

158. New York Times, December 17, 1978 p. 70, col. 3. See 1 Solar Law Reporter 1 (May/June 1979) at 10-11.

159. Ch. 361 , $\$ 1$, 1974 Fla. Laws; Fla. Stat. $\$ 553.87$ (Cum. Supp. 1972-1978).

160. Ch. 824, 1975 Nev. Stats.; Ch. 64, 1977 Nev. Stats; Nev. Rev. Stat. $\$ 341.260(3)$.

161. Ch. 12, \$ 1, 1976 Utah Laws; Utah Code Ann. \$ 63-9-46 (1977).

162. Ch. 17̄8, 1977 Utah Laws; Utah Code Ann. $\$ 63-9-48$.

163. For a comprehensive analysis of issues related to wind technologies, see Louis $\mathrm{H}$. Mayo, Legal-Institutional Implications of Wind Energy. Conversion Systems (WECS). Final Report. Washington, D.C.: George Washington University; 1977; NSF/RA-770204. See also Taubenfield, "Wind Energy: Legal Issues and Legal Barriers;" 31 Southwestern L.J. 5, (1977).

164. See the Dubin and Philips studies cited in Miller, et al., "Solar Access and Land Use: State of the Law 1977," Environmental Law Institute, Wash., D.C., at 3 (Available from Natl. Solar Heating and Cooling Information Center (800) 5232929). See also the Phoenix Project Report of the Colorado Springs, CO Dept. of Public Utilities, 1975.

165. See United States v. Causby, 328 U.S. 256, 260-261 (1945) for an explanation of the limits of the common law doctrine in an airplane case. The doctrine is "Cujus est solum, ejus est usque ad coleum," or 'whoever has the land possesses all the space upwards to an indefinite extent', or to the periphery of the universe. 
166. Fontainebleau Hotel Corp. v. Forty-Five Twenty-Five, Inc., 114 So.2d 357, 181 Fla. Supp. 74 (1959).

167. An easement is an interest for a limited use of land which belongs to someone else. A common example of an easement is a road across someone else's property. Easements can be created by several methods, of ten by express conveyance. Easements can also be created by implication. For example, if a piece of property is divided and one piece sold to a new owner, the new owner has the right to put the new land to beneficial use. If this cannot be accomplished without an easement, and if an easement was not expressly conveyed to the new owner, then an easement can arise by implication. Another way to create an easement is by prescription. A prescriptive easement is created when one person uses another person's land for a prescribed period of time and the use is continuous and adverse to the owner's use of the land. See Richard Powell, Powell On Real Property, Vol. 3 , ๆ 404-426.

168. See, e.g., People ex rel Haogasian v. Sears, Roebuck \& Co., 287 N.E.2d 677, 52 Ill.2d 301, cert. den. 409 U.S. 1001 (1972) (cited in Thomas, note 16 supra).

169. Ch. 1366,1978 Cal. Stats; to be codified at Cal. Pub. Res. Code $\$ \$ 25980-25986$.

170. See ELI Study, note 156, supra.

171. Kraye v. Old Orchard Assoc., No. C209453 (Superior Ct. Calif., 1978) (unreported). See Current Developments in 1 Solar Law Reporter 1 (May/June 1979) at 8.

172. Colo. Rev. Stat. \$\$ 38-32.5-101-102 (Cum. Supp. 1973-1976).

173. Id.

174. Ch. 1154,1978 Cal. Stats; to be codified at Cal. Civ. Code $\$ \$ 801-801.5$.

175. Ch. 309, $§ 2,1978$ Fla. Laws; Fla. Stat. Ann. $\$ \S 377.705(1)$-(4) (Supp. 1978).

176. Ch. 1446, 1978 Ga. Laws; to be codified at Ga. Stat. Ann. \$ 85-1411-1414 (Supp. 1978).

177. Ch. 294, 1978 Idaho Sess. Laws; Idaho Code $\$ 55-615(1)-(4)$ (1978).

178. Ch. 80-430, 1977 Ill. Laws; see generally Ill. Ann. Stat. Ch. 96-1/2 \$\$ 7301-7316 (Smith-Hurd Supp. 1978).

179. Id. $\$ 7304$.

180. Id. $\$(e)(1)$.

181. Id. $\$(f)(1)$.

182. Id. $\$(f)(2)$.

183. Id. $\$ 7308(\mathrm{c})$. 
184. Ch. 227, 1977 Kan. Sess. Laws; Kan. Stat. Ann. $\$ \$$ 58-3801-3802 (Cum. Supp. 19771978).

185. Ch. 227, $\$ 2,1977$ Kan. Sess. Laws.

186. Ch. 934, 1977 Md. Laws; Md. Real Property Code Ann. $\$ 2-118(7)(8)$ (1978 Supp.).

187. Ch. 786, $\$ 21,1978$ Minn. Laws; Minn. Stats. $\$ 116 \mathrm{H}$ (Supp. 1978).

188. Ch. 152, 1978 N.J. Laws. Source: National Conference of State Legislatures and NSHCIC.

189. Ch. 425, 1977 N.D. Sess. Laws; N.D. Cent. Code, $\$ \$ 47-05-01.1,-01.2$ (1978).

190. Ch. 323, 1978 Va. Laws; Va. Code $\$ 55-336,-338$.

191. Ch. 1154,1978 Cal. Stats; to be codified at Cal. Civ. Code $\$ 714$.

192. See ELI Study, note 156 supra, at 14.

193. Ch. 314, 1978 Conn. Pub. Acts; Conn. Gen. Stat. Ann. \$ 8-2 (zoning regs.), \$ 813(D), (TDRs and PUDs), $\$ 8-23$ (Master Plans); $\$ 8-25$ (Subdivisions); $\$ 8-35 a$ (Regional Comprehensive Plans) (1978).

194. Ch. 786, $\$ \$ 12-20,1978$ Minn. Laws; Minn. Stats. $\$ 394.25(2)$ (zoning regs.-solar access districts); $\$ 394.27(7)$ (variances); $\$ 462.357(1)$ (zoning regs.-general); $\$ 462.357(6)$ (boards of appeals); $\$ 462.358(2)$ (subdivisions); $\$ 462.358(6)$ (subdivision variances) $\$ 462.39(3)$ (comprehensive planning); $\$ 473.05$ (1) (comprehensive plans); $\$ 473.859(2)$ (local land-use plans) (Supp. 1978).

195. Ch. 153, 1975 Or. Laws; Or. Rev. Stat. $\$ 215.055(1)$ (comp. plans, zoning regs.); $\$$ $215.110(1)(\mathrm{c})$ (county ordinances); $\$ 227.090(2)$ (city plans); $\$ 227.230(2)$ (city setbacks) (1978).

196. Ch. 1154, 1978 Cal. Stats.; to be codified at Cal. Govt. Code $\$ \$ 66473.1,66475.3$.

197. Ch. 1366, 1978 Cal. Stats.

198. Solar Rights Act; Ch. 169, 1977 N.M. Laws, N.M. Stat. Ann. \$\$ 70-8-2 et seg. (Interim Supp. 1976-1977).

199. See White, "The Allocation of Sunlight: Solar Rights and the Prior Appropriation Doctrine," 47 University of Colorado Law Review 47 (1976) at 423, 443, for a proposed model statute upon which the New Mexico law is based.

200. See, e.g., ELI Study, note 156 supra, at 18, and the transcripts of the meeting of ABA Select Committee on Energy at SERI, April 14, 1978.

201. See ELI Study, note 156 supra.

202. Ch. 102, \$ 1, 1977 Laws of Hawaii; Hawaii Rev. Stat. \$\$ 269-1,-27.

203. Ch. 1102,1978 Cal. Stats.; to be codified at Cal. Pub. Util. Code $\$ 2775.5$. 
204. Ark. Stat. $\$ \S 73-2501$ to 2505 (Cum. Supp 1957-1977).

205. Ch. 80-430, 1977 Ill. Sess. Laws; Ill. Rev. Stat. Ch. 96-1/2 \$7315 (Supp. 1978).

206. Mont. Rev. Codes Ann. $\$ 84-7405$ (102) (Cum. Supp. 1947-1977).

207. This Montana law is discussed more fully in the loan section at note 129, supra.

208. Ch. 835, 1976 Cal. stats; Cal. Pub. Util. Code $\$ 454$ (a-c) West Supp. 1978).

209. Ch. 264, 1978 Kan. Sess. Laws; Kan. Stat. Ann. \$ 66-117 (Cum. Supp. 1972-78).

210. Ch. 80-431, 1977 Ill. Sess. Laws; Ill. Ann. Stat. Ch. 11-2/3, $\$ 38$ (Supp. 1978).

211. Ch. 80-431, 1977 Ill. Sess. Laws.

212. Ch. 1056,1978 Iowa Acts; to be codified at Iowa Code $\$ 476$.

213. Act of Nov. 9, 1978, Pub. L. No. 95-617, 92 Stat. 3117.

214. 16 U.S.C. $\$ 2611$.

215. See 16 U.S.C. $\$ 824$ a-3.

216. See 42 U.S.C. $\$ 6807$. 
APPENDIX A

STATE PROMOTIONAL ACTIVITIES

A-1 
SERI飬

A-2 


\section{APPENDIX A}

\section{STATE PROMOTIONAL ACTIVITIES}

Laws designed to promote or publicize solar energy, other than those discussed in the body of this article, fall into four major categories: (1) research, development, and demonstration laws; (2) policy and information activities; (3) statutes governing lifecycle costing and state construction; and (4) SERI/Sun Day support. Such bills range from comprehensive statutes to single-purpose resolutions which occasionally are uncodified. Because the main categories of such legislation of ten overlap, the laws will be described on a state-by-state basis. This is not meant to imply that the bills listed are the only relevant ones. For example, many statutes creating or governing state energy agencies are not included.

\section{A.1 RESEARCH, DEVELOPMENT, AND DEMONSTRATION (RD\&D)}

Laws in this category include those governing state-administered scientific research and commercialization activities using funds from state or federal sources. Demonstration projects, as the term is used here, include only projects that are not part of the state's own construction programs.

Twenty-three states are listed for legislation in this area. Such laws are the most significant of the statutes considered in this Appendix, both in terms of the amount of funds raised and spent, and in practical support for the refinement and application of diversified technologies adapted to local conditions.

\section{A.2 POLICY AND INFORMATION ACTIVITIES (P/I)}

These activities include executive and legislative committee studies of solar policy, developinint of leyislative proposuls, Informational activities, and educational efforts publicizing the existence of solar programs (e.g., tax credits and incentives, availability of $\mathrm{RD} \& \mathrm{D}$ funds). Twenty-four states are included in this category.

\section{A.3 LIFE-CYCLE COSTING AND STATE CONSTRUCTION (LCC and SC)}

Legislative authorizations to conduct studies on existing and planned state buildings to determine the long-term feasibility of solar and conservation retrofits and new applications are contained in this category. Some of this legislation may have an impact on building codes. Both life-cycle costing and state construction categories contain 10 states.

\section{A.4 SERI/SUN DAY (SERI/S)}

This category includes state efforts to encourage the Solar Energy Research Institute (SERI) to locate in particular states, and to encourage the observance of Sun Day, which began on May 3, 1978. 


\section{A.5 STATE BY STATE SUMMARIES}

\section{Arizona: RD\&D, P/I, SERI}

Arizona created a Solar Energy Research Commission (SERC) in 1975 [1]. A fifteenmember board is authorized to promote Arizona as a site for SERI, provide grant application assistance, implement the Solar Energy Research and Demonstration Act of 1974 [2], encourage local research, and collect and disseminate information on in-state solar activities. The Commission was originally scheduled to expire at the end of 1978, but this termination date was repealed in 1977 [3].

Legislation relating to the national SERI was passed in 1976. Authority for site location was granted in 1976, whereby the Board of Regents of the State Universities was empowered to convey 300 acres for SERI, if necessary [4]. A resolution endorsing Arizona as a desirable location for SERI was also passed in 1976 [5]. Minor legislation relating to appropriations for the SERC [6], and granting to SERC the authority to charge for publications [7], was also passed in 1976. Another resolution urging the accelerated development and use of renewable energy sources was passed in 1977 [8].

\section{Arkansas: RD\&D, P/I}

Pursuant to a resolution authorizing legislative committee study to develop tax and other solar incentives, Arkansas passed an Energy Conservation and Policy Act of 1977 [9]. The Act was designed to promote the use of a diverse array of energy resources with emphasis on indigenous and renewable resources. A State Energy Conservation and Policy Office was also created which was empowered to develop a conservation program, monitor programs, recommend legislation, and compile an energy data base. Information acquisition powers were subsequently limited in order to protect the competitive position of corporations making disclosures [10].

\section{California: $\mathrm{P} / \mathrm{I}, \mathrm{RD} \& \mathrm{D}, \mathrm{LCC}, \mathrm{SC}, \mathrm{s}$}

In 1974, California created the State Energy Résources Conservation Development Commission [11]. Its mandate was, among other things, to carry out studies, research projects, and data collection on solar energy [12]. In 1977, life-cycle costing work was added to the Commission's duties [13]. Specifically, the Commission is required to prepare a manual on life-cycle costing standards and guidelines for new state buildings (Title 24). Most significantly, new state buildings over $10,000 \mathrm{ft}^{2}$ in floor area must now include supplementary solar hot water heaters, unless specifically exempted.

On February 17, 1978, a resolution declaring support for the impending Sun Day was passed [1 4].

In 1978, California passed several laws to promote solar energy use. One bill requires the Public Utilities Commission to investigate the feasibility of alternative methods of providing low-interest, long-term financing of solar energy systems [15]. The state Energy Resources Conservation and Development Commission is required by another statute to develop a plan for the maximum feasible use of solar energy in the state by 1990 [16].

Prior to 1978, no county water districts were authorized to purchase and resell solar energy devices. In 1978, enabling legislation allowed the North Marin County Water District to engage in this activity [17]. The legislature also authorized a statewide 
architectural design competition for passive solar design features, and appropriated $\$ 315,000$ for that purpose.

\section{Colorado: RD\&D, P/I, SERI, LCC}

In 1974, Colorado created the Colorado Energy Research Institute (CERI) to develop and coordinate programs relating to energy and energy-related minerals [18], with emphasis on research programs and educational development. CERI was initially involved in successful search for a manager-operator (Midwest Research Institute) for the Colorado SERI proposal. The legislature authorized a free conveyance of land for the SERI site, in the Solar Energy Research and Development Act of 1977 [19], following a resolution supporting this intent [20], and appropriations for the proposal [21]. Golden, Colorado was ultimately chosen for the SERI site. Life-cycle costing for major facilities over $20,000 \mathrm{ft}^{2}$ is required pursuant to a 1976 act which created a state office of planning and budgeting primarily for this purpose [22].

\section{Florida: RD\&D, P/I, LCC}

In 1974, the Florida legislature authorized the state Board of Regents to develop plans for a Solar Energy Center, whose main functions are to advance R\&D, disseminate information, demonstrate solar feasibility, test solar equipment, develop educational and grant-assistance programs, and assist standards development [23]. In 1978, mandatory life-cycle costing considerations in state construction were amended to require the use of solar energy systems where they are found to be most cost-efficient [24].

\section{Georgia: P/I, SERI}

In 1976, Georgia created an Office of Energy Resources, designed in part to "insure the development and placement into the marketplace of viable alternate energy resources" by evaluating state energy policies, coordinating state programs, and recommending legislation [25]. An energy extension service program was subsequently created as a subunit to disseminate energy information and to provide technical assistance [26]. A 1976 resolution, which listed the support of Kentucky, Louisiana, and Mississippi, promoted Georgia for a SERI location [27].

\section{Hawaii: RD\&D, P/I, SC}

Multi-year RD\&D funds deriving from general obligation bond proceeds were provided in 1974 for alternate energy sources. The funds went primarily to the Hawaii Natural Energy Institute, and to the Hawaii National Energy Laboratory, which was created in the same year [28]. A 1977 resolution called for a study by the Energy Resources Coordinator of legal and institutional impediments to solar energy [29]. The study is meant to culminate in recommendations for remedial action. Another resolution in that same year called for a feasibility study on installing solar energy devices in existing public buildings. The governor had previously announced his intention to install such systems in new public building construction [30].

\section{Illinois: RD\&D, P/I, LCC, SC}

Solar RD\&D was provided for in the minois Coal and Energy Development Bond Act of 1977 [31]. Of $\$ 70,000,000$ expected to be raised by general obligation bonds, $\$ 5,000,000$ is intended to be used for "other forms of energy," including "solar energy... wind generation, solid waste..." and excludes nuclear power. Also in 1977, the Illinois legislature passed a bill authorizing a Comprehensive Energy Plan, to be developed by state colleges 
and universities [32]. The plan will address conservation, $R D \& D$, and building management.

\section{Iowa: RD\&D, SC}

In 1975, Iowa created an Energy Research and Development Fund within the Energy Policy Council, to promote increased research and development of both traditional and renewable energy sources [33]. In 1977, the Iowa legislature appropriated $\$ 200,000$ for a demonstration solar energy unit to convert solar energy to steam for use in the statehouse complex [34].

In 1978, the legislature created a comprehensive solar energy program including a plan for demonstration projects in public and private buildings. The Council was directed to develop an incentive and demonstration program for encouraging the construction and use of cost-effective and diverse solar energy systems. Other sections of the comprehensive plan direct the Council to institute public educational programs, sturly nuhlic: utilities and joint solar systems, and propose solar skyspace easement legislation [35].

\section{Kansas: LCC, SC, P/I}

A 1977 concurrent resolution directed the Department of Administration to "cause" the installation of solar heating and cooling systems in all new state-owned construction, unless life-cycle costing indicates otherwise [36]. A feasibility study concerning demonstration projects in existing buildings was also requested.

\section{Kentucky: RD\&D, P/I}

In 1976, a Center for Energy Research and a Department of Energy were created to broadly research "natural energy sources," although solar energy wasn't specifically mentioned [37].

\section{Maine: RD\&D, P/I}

In 1975, Maine reenacted enabling legislation for the state Office of Energy Resources to immediately initiate informational activities, governmental coordination, federal grant assistance, formulation of a comprehensive energy policy, and research administration via an Energy Resources Development Fund [38]. A 1978 amendment added solar energy to the listing of renewable resources to be researched [39]. This amendment was accompanied by a $\$ 16,000$ appropriation for the administration of the HUD Solar Hot Water Heater Demonstration program. These funds are to generate forty $\$ 400$ grants.

\section{Maryland: $\mathbf{P} / \mathbf{I}$}

A 1976 resolution called for the development of legislative proposals for solar commercialization, and the gubernatorial appointment of a Solar Energy Commission [40].

\section{Massachussetts: LCC}

A 1976 act provided for life-cycle cost analysis on energy systems for new buildings and additions costing more than $\$ 25,000$ [41]. The Bureau of Building Construction is to summarize the estimates and regulate the new procedures. 


\section{Minnesota: SC, P/I, RD\&D}

A $\$ 50,000$ feasibility study for incorporation of solar energy into architectural plans for a new prison was authorized in 1977 [42]. An Energy Conservation Information Center was created in 1976, with information coverage to include alternative sources of energy [43]. Alternative energy research grants were authorized in 1977 , accompanied by substantial appropriations for two years [44]. At least one-quarter of the funds were to be applied to projects with a "high potential for commercialization" [45].

A comprehensive solar study by the State Energy Agency aimed at formulating solar legislation, was authorized in 1977 [46]. This legislation also created and funded a gasahol $R \& D$ program emphasizing diesel fuel for agricultural engines. A final provision was made for publicity for energy conservation, which was redefined to include the evaluation of energy systems related to heating and cooling.

\section{Montana: RD\&D, P/I}

An RD\&D fund for alternate renewable energy resources was created in 1975 [47]. The fund receives $2.5 \%$ of license and coal severance taxes (increasing to $4 \%$ in 1980). Provision was also made for publicizing tax incentives.

\section{Nebraska: SERI, SC}

A resolution encouraging in-state location of SERI was passed in 1976 [48].

In 1977,6 out of 63 state construction projects were designed to include solar applications, and funds were appropriated to that end [49]. One of the projects was a pilot study on heating an indoor-outdoor swimming pool. The largest appropriation- $\$ 160,000$ for solar hot water in the University of Nebraska construction program-was deemed a "high priority" by the legislature, but half of the $\$ 1.4$ million required by the entire project was vetoed.

\section{Nevada: RD\&D}

A 1975 act appropriated $\$ 370,000$ for construction of a Solar Energy Laboratory as part of the Desert Research Institute of the University of Nevada [50].

\section{New Jersey: SERI}

The 1976 legislature resolved to promote New Jersey as the SERI site [51].

\section{New Mexico: LCC, SC, RD\&D, P/I, SERI}

Lif e-cycle costing was established in 1975 by an act requiring a feasibility study on the use of nonfossil energy sources for heating and cooling in "major" new or altered state buildings [52]. Also in $1975, \$ 30,000$ was appropriated to the Department of Development to promote in-state solar research and commercialization, and the attraction of SERI [53].

In a 1977 act very similar to Montana's 1975 law, $\$ 2,500,000$ from the severance tax fund was appropriated to the Energy Research and Development Fund [54]. Of that amount, a minimum of $\$ 500,000$ is earmarked for use by the Board of Regents to develop solar performance standards, test solar equipment, coordinate $R D \& D$, collect and disseminate solar energy information, and coordinate state and federal programs. 
A 1977 general construction appropriations bill applied severance tax proceeds to finance $\$ 500,000$ of solar collectors at Grants College of NMSU [55]. Other projects funded from this source would be eligible for a $10 \%$ increase in appropriations if $75 \%$ of the building would be heated with solar energy. Two other appropriations were vetoed as moot: a $\$ 1.5$ million SERI site-appropriation; and $\$ 67,000$ intended for solar water heating of public secondary schools.

New York: RD\&D, P/I

In 1975, New York redesignated its Atomic and Space Development Authority as the New York State Energy Research and Development Authority (ERDA) [56]. The bill, labeled a "Safe Energy Act,". authorized ERDA to develop new energy sources including solar, and to pursue $R D \& D$, informational, and legislative recommendations.

A 1976 "Energy Law" created a State Energy Office to work with ERDA [57]. Its chief functions are studying state energy policies, providing an information clearinghouse, promulgating energy-use standards for state buildings, promoting accelerated use of renewable energy sources, and encouraging the "new ethic" of conservation.

In 1978, the environmental conservation code was amended to encourage and promote the development of "small head hydro, ... solar, wind, solid waste, energy from biomass," among other energy resources [58].

\section{North Carolina: LCC, SC, RD\&D}

A life-cycle costing bill was passed in 1975 [59], which applies to new facilities constructed, guaranteed, or insured with state funds. Renovations to buildings over $40,000 \mathrm{ft}^{2}$ are also covered. All state agencies are empowered to conduct the analyses.

A 1976 act appropriated $\$ 30,000$ to the state university for research and development of a working SHAC system applicable to commercial and residential buildings [60]. A further appropriation of $\$ 125,000$ was made in 1977 to assist the development of a reliable and easily maintainable solar thermal conversion unit capable of producing 1,000 $\mathrm{kWh} / \mathrm{month}[61]$. Some of the funds may be used for a demonstration at the State Fair.

\section{Ohio: RD\&D, P/I}

A 1975 act established the Ohio Energy and Resource Development Agency (ERDA), replacing two earlier energy agencies [62]. Five million dollars were appropriated for research and demonstation, and loan, grant, and contract sponsorship for projects including alternate energy sources.

\section{Oklahoma: RD\&D, P/I}

A 1977 Resolution authorized the State Department of Energy to conduct a study of "alternative" and supplemental energy sources, including nuclear (sic) and solar energy for possible use by state boards and agencies [63]. The Department was created in 1974, and was originally empowered to, inter alia, collect conservation data [64].

\section{Oregon: RD\&D, P/I}

In 1977 the Director of Extension Services was directed to "formulate information relating to the construction and use" of SHAC systems, and to distribute such information to the public via County Agents [65]. 
Another 1977 act established an Energy Conservation and Production Fund to assist utilities and individuals in developing nonnuclear energy sources [66]. Small-scale and environmentally benign projects were to be stressed. Loans would have become available, but the voters rejected the act in the November 1978 election [67].

\section{Rhode Island: $\mathbf{P} / \mathbf{I}$}

Two resolutions created and extended a State Energy Technology Study Commission to report on solar and wind energy by March 16, 1977 [68]. A legislative commission was created in 1977 to study the economic potential of solar technologies, and to study the "feasibility of financial and tax incentives to encourage the implementation of energy conservation alternatives" [69].

\section{South Carolina: S}

A Sun Day concurrent resolution was passed less than a month before the May 3, 1978 event [70]. General support for increased government RD\&D was expressed.

Tennessee: $\mathbf{P} / \mathbf{L}, \mathrm{SC}, \mathrm{RD} \& \mathrm{D}$

The Tennessee Energy Act of 1977, empowered the Energy Authority (formerly the Energy Office) [71] to guide the general direction of energy policy, control and coordinate state building energy use, conduct informational activities, control and coordinate $\mathrm{RD} \& \mathrm{D}$ in solar energy and renewable energy resources, and to report on the current solar market structure.

\section{Texas: LCC, RD\&D}

The Energy Conservation in Public Buildings Act of 1975, promotes life-cycle costing [72]. The State Building Commission (SBC) is to develop energy performance standards for various classes of state buildings. Authorities exempted from SBC standards are required to create their own. Model energy conservation city codes and design and construction manuals for residential and commercial buildings are also required. A 1977 resolution encouraged more specific feasibility studies for "alternative, nonexhaustible energy sources" [73]. The Texas Energy Development Act of 1977 declared a public need for government support of alternative energy technologies [74]. Out of a $\$ 5$ million fund, $\$ 1.5$ million. was appropriated to sular, biomass, and wind energy $K D \& D$.

\section{Utah: P/I, SERI}

A 1977 resolution belatedly promoted Utah as the site for SERI [75]. A "comprehensive energy policy" for Utah, based on a committee report, was concurrently adopted [76], terming "desirable" the conservation and development of renewable energy resources (solar, wind, and geothermal). This resolution also recognized that the main focus of the energy policy would be the development of coal. An Energy Conservation and Development Council was subsequently created to implement the state energy policy, but there were no direct solar references in the enabling legislation [77]. A resolution was also passed requiring further study of the newly adopted energy policy, for the purpose of developing legislative proposals [78].

\section{Vermont: SERI}

A 1976 resolution endorsed New England as the site for SERI, and encouraged an inventory of state and private solar resources in Vermont [79]. 


\section{Virginia: $\mathbf{P} / \mathbf{I}, \mathbf{R D \& D}$}

In 1975, legislation created a Solar Energy Center within the state Science Museum [80]. In 1977, the Center was transferred to the Virginia Energy Office [81]. The purposes of the Center are to provide an information clearinghouse, coordinate datagathering, coordinate federal and state programs, promote private and public cooperation, develop public educational programs, and provide policy assistance.

\section{Washington: LCC, P/I, RD\&D}

Life-cycle costing was authorized in 1975 for all public agencies [82]. "Major" public facilities of over $25,000 \mathrm{ft}^{2}$ that will be newly built or $50 \%$ renovated are subject to the law. The energy cost analysis compares three systems over one year of simulated operation, and estimates long-term energy consumption, maintenance, and finance costs. In 1976, a State Energy Office was created with conventional powers and duties relating to information, coordination, $R \dot{D} \& D$, etc. [83]. This legislation declared a new state policy encouraging the development of a "diverse array of energy resources with emphasis on renewable energy resources." 


\section{APPENDIX A}

\section{REFERENCES}

1. Ch. 20, $\$ 2,1975$ Ariz. Sess. Laws; Ariz. Rev. Stat. $\$ \$ 41-571$ to 574 (Supp. 1978 ).

2. 42 U.S.C. $\$ 5551$ et seq.

3. Ch. 58, 1977 Ariz. Sess. Laws; Ariz. Rev. Stat. $\$ \$ 41-572(B), 574(9)-(10)$ (Supp. 1978).

4. Ch. 156, §6, 1976 Ariz. Sess. Laws; Ariz. Rev. Stat. $\$ 41-574$ (Supp. 1978).

5. S.J.R. No. 1002, 1976 Ariz. Sess. Laws; Ariz. Rev. Stat. \$ 41-574 (Supp. 1978).

6. Ch. 3, 1976 Ariz. Sess. Laws.

7. Ch. 12, 1976 Ariz. Sess. Laws; Ariz. Rev. Stat. $\$ 41-575$ (Supp. 1978).

8. H.C.R. No. 2013 , Ariz. Sess, Laws of 1977.

9. Ch. 103, 1977 Ark. Acts; Ark. Stat. Ann. \$\$ 5-1301-1309 (Supp. 1977).

10. Ch. 426, 1977 Ark. Acts; Ark. Stat. Ann. \$\$ 5-1304(b), -1305(a) (Supp. 1977).

11. Ch. 276, 1974 Cal. Stats; Cal. Pub. Res. Code $\$ \$ 25400-25600$ (West Supp. 1977).

12. Id. $\$ \S 25401,25600(\mathrm{c})$.

13. Ch. 773, 1977 Cal. Stats; Cal. Pub. Res. Code $\$ \$ 25487-25498$ (West Supp. 1977).

14. A. R.R. No. 105, Roo. Ch. 27, 1070 Cal. 3tats.

15. Ch. 1100,1978 Cal. Sess. Laws; to be codified at Cal. Pub. Util. Code $\$ 2851$.

16. Ch. 1155,1978 Cal. Sess. Laws; to be cudifled at Cal. Püb. Kes. Code $\$ 25309.5$.

17. Ch. 1101,1978 Cal. Sess. Laws; to be codified at Cal. Water Code $\$ 31052$.

18. Ch. 95, 1974 Colo. Sess. Laws; Colo. Rev. Stat. \$\$ 124-9-19, -20 (Supp. 1974).

19. Ch. 342,1977 Colo. Sess. Laws; to be codified in Colo Rev. Stat. $\$ 24-82-50.1$ (Cum. Supp. 1973-1975).

20. H.J.R. 1034, 1970 Colü. Bess. Luws.

21. Ch. 20, 1976 Colo. Sess. Laws.

22. Ch. 116, 1976 Colo. Sess. Laws; Colo. Rev. Stat. $\$ \$ 24-37-100.2,-100.3,-103,-104$, -107 (Cum. Supp. 1973-1976).

23. Ch. 187, I9'/4 F'la. Laws; Fla. Stat. Ann $\$ 255.255(5)$ (West 1975). 
24. Ch. 27, 1978 Fla. Laws; Fla. Stat. Ann. $\$ 255.254(2)$ (West Supp. 1977).

25. Acts of 1976, 1976 Ga. Laws; Ga. Code Ann. $\$ \$ 40-436$ to 438 (Cum. Supp. 19751978).

26. H.R. No. 208-823, Res. Act. No. 29, 1977 Ga. Laws.; (uncodified).

27. H.R. No. 378 (no Res. act. \# or date available), 1976 Ga. Laws.

28. Ch. 235 and Ch. 236, 1974 Haw. Sess. Laws (Natural Energy), omitted from Haw. Rev. Stat.

29. S.R. 62, S.C.R. No. 86, 1977 Haw. Sess. Laws.

30. H.R. 427, 1977 Haw. Sess. Laws.

31. Ch. 432, 1977 ll. Laws; Hl. Ann. Stat. Ch. 93, $\$ \$ 402,407$ (Cum. Supp. 1964-1978).

32. Ch. 433, 1977 Ill. Laws; Ill. Ann. Stat. Ch. 144, $\$ 186.3$ (Cum. Supp. 1964-1978).

33. Ch. 56, 1975 Iowa Acts; Iowa Code $\$ 93.14$ (Cum. Supp. 1972-1978).

34. Ch. 16, 1977 Iowa Acts.

35. Ch. 1056, $\$ \$ 4-9,1978$ Iowa Sess. Laws.

36. S.C.R. No. 1601,1977 Kan. Sess. Laws.

37. Ch. 299, 1976 Ky. Acts; Ky. Rev. Stat. $\$ 152$ A .011-.180 (Oct. 1975).

38. Ch. 587, 1975 Me. Acts; Me. Rev. Stat. tit. 5, SS 5004-5009 (Supp. 1978).

39. Ch. 685, 1978 Me. Acts; Me. Rev. Stat. tit 5 \$ 5005(G) (Supp. 1978).

40. H.J.R. No. 48, 1976 Md. Laws.

41. Ch. 433, 1976 Mass. Laws; Mass. Ann. Laws. Ch. 149, $\$ 44 M$ (Michie/Law Co-op Cum. Supp. 19'(6-19'78).

42. Ch. $451, \$ 1,1977$ Minn. Laws.

43. Ch. 333, 1976 Minn. Laws; Minn. Stat. Ann. \$ 116H.085 (1977).

44. Ch. 455, 1977 Minn. Laws.

45. Ch. 381 , 1977 Minn. Laws; Minn. Stat. Ann. \$ 116H.087 (Supp. 1977).

46. Id. at $\$ 116 \mathrm{H.07i}$.

47. Ch. 501, 1975 Mont. Laws; Mont. Rev. Codes Ann. $\$$ 84-1319(b) (Cum. Supp. 19661977).

48. L.R. 104, 1976 Neb. Laws. 
49. Ch. 549 , $\$ \S 14.35,36,38,43,44,1977$ Neb. Laws.

50. Ch. 636, 1975 Nev. Laws; Nev. Rev. Stat. \$ 369.7956 (1975).

51. A.C.R. 167,1976 N.J. Laws.

52. Ch. 200, 1975 N.M. Laws; N.M. Stat. Ann. $\$ 6-2-29.1$ (Supp. 1975).

53. Ch. 83, 1975 N.M. Laws; N.M. Stat. Ann. $\$ \$ 4-37-2,-3$ (Supp. 1975).

54. Ch. 347, 1977 N.M. Laws.

55. Ch. 91, 1977 N.M. Laws.

56. Ch. 864, 1975 N.Y. Laws; N.Y. Public Authorities Law $\$ 1854$ (i)(c) (McKinney Cum. Supp. 1970-1978).

57. Chapters 819-821, 1976 N.Y. Laws; N.Y. Energy Law $\$ \$ 1-101$ to 7-103 (inclusive) (McKinney Supp. 1977).

58. Ch. 396, 1978 N.Y. Laws, to be codified at N.Y. Env. Consv. Law $\$ 2361$, N.Y. Energy Law \$§ 3-101, 5-107.

59. Ch. 434,1975 N.C. Sess. Laws.

60. Ch. 911,1976 N.C. Sess. Laws.

61. Ch. 971, 1977 N.C. Sess. Laws.

62. H.B. Sub. 584, 1975 Ohio Sess. Laws; Ohio Rev. Code Ann. $\$ 122.63$.

63. H.J.R. No. 1013,1977 Okla. Sess. Laws.

64. Ch. 1, 1974 Okla. Sess. Laws; Okla. Stat. Ann. tit. 74, $\$ 3370$ (West Supp. 1978).

65. S.J.R. 18, 1977 Or. Laws.

66. S.B. 572 , Ch. 732,1977 Or. Laws.

67. S.J.R. 32, 1977 Or. Laws.

68. Res. No. 59, 1975 R.I. Acts and Resolves; Res. No. 131, 1976 R.I. Acts and Resolves.

69. Res. No. 287, 1977 R.I. Acts and Resolves.

70. H. 3968, 1977 S.C. Acts.

71. Ch. 303, 1977 Tenn. Pub. Acts; Tenn. Code Ann. $\$ \$ 4-2801$ to 4-2822 (Supp. 1977).

72. Ch. 89, 1975 Tex. Gen. Laws. Vernon's Ann. Rev. Civ. Stat. of Texas art. 678i, \$\$ 13 (1977). 
73. H.S.R. No. 24, 1977 Tex. Gen. Acts.

74. Ch. 838, 1977 Tex. Gen. Acts; Vernon's Ann. Rev. Civ. Stat. of Texas art. 4413(47b), \$\$ 1-9 (1977).

75. S.C.R. No. 2, 1977 Utah Laws.

76. S.C.R. No. 1, 1977 Utah Laws.

77. Ch. 177, 1977 Utah Laws; Utah Code Ann. \$ 63-53-1 (Supp. 1978).

78. S.J.R. No. 37, 1977 Utah Laws.

79. J.R.S. 35, Res. No. 63,1976 Vt. Acts.

80. Ch. 331, 1975 Va. Acts; Va. Code \$ y-65.2:1 (répéáleđ) (1978).

81. Ch. 601, 1977 Va. Acts; Va. Code $\$ 10-214$ (repealing $\$$ 9-65.2:1).

82. S.B. 2016, Ch. 1777, 1975 Wash. Laws; Wash. Kev. Code $\$ \$ 39.35 .010-.900$ (P.P. 1977).

83. Sec. 4, Ch. 108, 2nd Ex. Sess., 1976 Wash. Laws; Wash. Rev. Code $\$ \$ 43.21$ F.010.070 (P.P. 1977). 
APPENDIX B

FINDING THE LAW

B-1 


\section{S=P1荢}

B-2 


\section{APPENDIX B}

\section{FINDING THE LAW}

Codifications of enacted bills are valuable for at least three reasons. First, they facilitate access to the current law for legislators, designers, builders, consumers, bureaucrats and lawyers. Second, the legal importance of legislation lies not in the language of a bill as passed, but as it appears in the state code. The codifications are frequently abbreviated versions of a bill, and put its language in the proper context of the extant laws. Finally, as a research methodology, location of codifications is the most thorough method of discovering solar legislation.

Although search of codifications is time-consuming and time-limited (by delayed publication of code supplements), locating codifications has resulted in the discovery of several laws or amendments previously unreported by the organizations actively involved in tracking certain areas of solar legislation: the National Conference of State Legislatures (NCSL-Energy Policy Project) [1], and the National Solar Heating and Cooling Information Center (NSHCIC-Franklin Institute) [2]. The NSHCIC has limited itself to the solar heating and cooling of buildings (SHACOB). An excellent third source of information on state solar legislation (1974-1976) relating to buildings is contained in two volumes by Robert M. Eisenhard [3] of the National Bureau of Standards. Other summaries by the Southern Conference of State Legislatures, and Consumer Action Now, are also useful references [4].

The three major summary sources of information have their limitations. The NCSL format is simple and readable, yet its chronological approach forces the reader to collate isolated references to find the current status of the law. The NSHCIC format is stateby-state, but it is terse in its summations and necessarily omits important details, in addition to non-SHACOB legislation. Proposed bills and bill copies are available from them on request. Both the NCSL and NSHCIC cite the laws only by bill number or chapter law of a certain year. However, most libraries keep only the most current sesslun's' laws availabie on the shelves. Many states (Maryland for example) do not have parallel tables of bill, chapter, and code numbers which facilitate location of codifications of older laws. These reference sources have nevertheless been a valuable aid to researchers in the solar field, including the author, who expresses his gratitude for research assistance and advice.

Searching for the current status of solar law in the code books has numerous drawbacks. Code indices frequently contain no reference to "solar" under various headings despite the presence of one or more solar laws in the state [5]. One bill may be codified in multiple sections. . Codifications are generally outdated by up to a year, even when supplemented. Finally, codifications generally give no indication of repealed and proposed legislation. The Eisenhard volumes are the only ones that offer codification citations (along with pertinent forms, bill copies, and empirical data). Yet they continue only through 1976, and the citations reflect the bills only as they were intended to be codified. Resolutions, for example, are rarely codified. Occasionally the compiler changes the intended codification or adds new code numbers. Citations as used herein generally utilize official state code numbers, as compiled. 


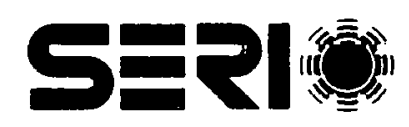

B-4 


\section{APPENDIX B}

\section{REFERENCES}

1. See Energy Report to the States, "State Solar Legislation 1974-77" Vol. 4, No. 8, April 28, 1978.

2. See "State Solar Legislation," January 1979, available upon request. Toll-free telephone (800) 523-2929.

3. See R. M. Eisenhard, A Survey of State Legislation Relating to Solar Energy. Washington, D.C.: National Bureau of Standards; April, 1976; NBSIR 76-1082. Avail.: NTIS, PB 258235; R. M. Eisenhard, State Solar Energy Legislation of 1976: A Review of Statutes Relating to Buildings. Washington, D.C.: National Bureau of Standards, September, 1977; NBSIR 77-1297. Avail.: NTIS, PB 273899. A more current edition is being compiled.

4. Joan E. Porte, "Solar Legislation of the Fifty States," Consumer Action Now, Washington, D.C., April 19, 1978;. See also The Book of the States 1978-79, Council of State Governments, $\mathrm{Ky}$. This is an excellent general reference for purposes of gaining background information on all varieties of state laws and programs, including information about taxation. In addition, see a short discussion of limited selections of state legislation by the Electric Power Committee of the Natural Resources Section of the American Bar Assoc., in "Annual Review of Significant Activities of 1977", XI Natural Resources Lawyer, 1 (1978), at 21-28.

5. Indeed, one minor but useful reform might be the addition of one or more solar headings in legislative and other legal indices. 


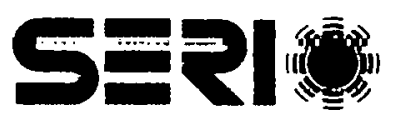

B-6 
APPENDIX C

STATE CODIFICATION AND LEGISLATION CITATIONS

C-1 


\section{SEPI}

C-2 


\section{APPENDIX C \\ STATE CODIFICATION \& LEGISLATION CITATIONS}

$\underline{\text { State }}$

Alabama

Alaska

Arizona

Arkansas

Calif ornia

Colorado

Connecticut

Delaware

District of

Columbia

Florida

Georgia

Hawaii

Idaho

Illinois

Indiana

Iowa
Abbr.

Ala.

Alas.

Ariz.

Ark.

Cal.

Colo.

Conn.

Del.

D.C.

Fla.

Ga.

$$
\begin{gathered}
\text { Codification } \\
\text { (in order of } \\
\text { preference) }
\end{gathered}
$$

Ala Code tit. $\mathrm{X}, \S \mathrm{X}$

Alaska Stat. $\$ \mathrm{X}$

Ariz. Rev. Stat. $\$ \mathrm{X}$

Ark. Stat. Ann. $\$ \mathrm{X}$

Cal [subject] Code

$\checkmark \mathrm{X}$ (West)

Colo. Rev. Stat. $\$ \mathrm{X}$

Conn. Gen. Stat. § X

Conn. Gen. Stat. Ann.

S X (West)

Del. Code tit. X, $\S \mathrm{X}$

D.C. Code $\$ X$

Fla. Stat $\$ X$

Fla. Stat Ann. S $\mathrm{X}$

G.A. Code $\$ X$

G.A. Code Ann. $\$ X$

Haw. Rev. Stat. $\S \mathrm{X}$

Idaho Code $\$ \mathrm{X}$

IIl.

III Rev. Stat. Ch. X, $\$ \mathrm{X}$

Ill. Ann. Stat. Ch. X,

$\$ \times$ (Smith-Hurd)

(name act \& original $\$ \#$;

above numbering unofficial)

Ind. Code $\$ X$

Ind. Code Ann. $\$$ X (Burns)

Iowa Code $\$ \mathrm{X}$

Iowa Code Ann. $\$ \mathrm{X}$ (West)
Session Laws

19xx Ala. Acts

19xx Alaska Sess. Laws

19xx Ariz. Sess. Laws

19xx Ark. Acts

19xx Cal. Stats.

19xx Colo. Sess. Laws

19xx Conn. Pub. Acts

Del. Laws

19xx D.C. Code

Legis. \& Adm. Service

19xx Fla. Laws

19xx Ga. Laws

19xx Haw. Sess. Laws

19xx Idaho Sess. Laws

19xx Ml. Laws

19xx Ind. Acts

19xx Iowa Acts 


\begin{tabular}{|c|c|c|c|}
\hline State & Abbr. & Codification & Session Laws \\
\hline Kansas & Kan. & Kan. Stat. Ann. $\$ X$ & 19xx Kan. Sess. Laws \\
\hline Kentucky & Ky. & $\begin{array}{l}\text { Ky. Rev. Stat. } \$ \text { X } \\
\text { Ky. Rev. Stat. Ann. } \$ \text { X } \\
\text { (Baldwin) }\end{array}$ & $19 x x \mathrm{Ky}$. Acts \\
\hline Louisiana & La. & $\begin{array}{l}\text { La. Rev. Stat. Ann. } \\
\S \mathrm{X} \text { (West) } \\
\text { La. Civ. Code Ann. } \\
\text { art. X (West) }\end{array}$ & 19xx La. Acts \\
\hline Maine & Me. & $\begin{array}{l}\text { Me. Rev. Stat. } \\
\text { tit. X, } \$ \mathrm{X}\end{array}$ & 19xx Me. Acts \\
\hline Maryland & Md. & $\begin{array}{l}\text { Md. [subject] Code } \\
\text { Ann. \$ X } \\
\text { Md. Ann. Code (1957) } \\
\text { art. X, } \$ \text { X }\end{array}$ & 19xx Md. Laws \\
\hline Massachusetts & Mass. & $\begin{array}{l}\text { Mass. Gen. Laws. Ann. } \\
\text { Ch. X, } \$ \text { X } \\
\text { Mass. Ann. Laws. Ch. X, } \$ \text { X } \\
\text { (Michic/Law Co-op) }\end{array}$ & 19xx Mass. Laws \\
\hline Michigan & Mich. & $\begin{array}{l}\text { Mich. Comp. Laws Ann. } \$ \mathrm{X} \\
\text { Mlch. Stat. Ann. } \$ \mathrm{X}\end{array}$ & 19xx Mich. Pub. Acts \\
\hline Minnesota & Minn. & $\begin{array}{l}\text { Minn. Stat. } \$ \mathrm{X} \\
\text { Minn, Stat, Ann. } \$ \mathrm{X} \text { (West) }\end{array}$ & 19xx Minn. Lows \\
\hline Mississippi & Miss. & Miss. Code Ann. $\$ X$ & 19xx Miss. Laws \\
\hline Misoouri & Mo. & $\begin{array}{l}\text { Mo. Rev. Stat. } \$ \mathrm{X} \\
\text { Mo. Ann. Stat. } \$ \mathrm{X} \text { (Vernon) }\end{array}$ & 19xx Mo. Laws \\
\hline Montana & Mont. & Mont. Rev. Codes Ann. $\varsigma \mathrm{X}$ & 19xx Mont. Laws \\
\hline Nebraska & Neb. & Neb. Rev. Stat. $\$ \mathrm{X}$ & 19xx Neb. Laws \\
\hline Nevada & Nev. & Nev. Rev. Stat. $\$ \mathrm{X}$ & $19 x \times$ Nev. Stats. \\
\hline New Hampshire & N.H. & N.H. Rev. Stat. Ann. $\S \mathrm{X}$ & $19 x \times$ N.H. Laws \\
\hline New Jersey & N.J. & $\begin{array}{l}\text { N.J. Rev. Stat. } \$ X \\
\text { N.J. Stat. Ann. } \$ \text { X (West) }\end{array}$ & 19xx N.J. Laws \\
\hline New Mexico & N.M. & N.M. Stat. Ann. $\S \mathrm{X}$ & 19xx N.M. Laws \\
\hline New York & N.Y. & $\begin{array}{l}\text { N.Y. [subject] Law } \\
\text { (McKinney) }\end{array}$ & 19xx N.Y. Laws \\
\hline
\end{tabular}




\section{State}

North Carolina

North Dakota N.D.

Ohio

Oklahoma

Oregon

Pennsylvania

N.C.

Ore.

$\mathrm{Pa}$.

Okla.
Abbr.

Oklahoma
Oregon
Pennsylvania

Rhode Island

Okla. Stat. tit. X, $\$ X$ Okla. Stat. Ann. tit. X, $\S \mathrm{X}$ (West)

Ohio Rev. Code Ann.

$\$ \mathrm{X}$ (Page)

Ohio Rev. Code Ann. $\$$ X

(Baldwin)

N.C. Gen. Stat. $\$ X$

N.D. Cent. Code $\$ X$

19xx N.C. Sess. Laws

19xx N.D. Sess. Laws

19xx Ohio Laws

19xx Okla. Sess. Laws

Or. Rev. Stat. $\$ X$

19xx Or. Laws

19xx Pa. Laws
R.I.

S.C.

South Carolina

$X$ Pa. Cons. Stat. $\$ X$

$\mathrm{X}$ Pa. Cons. Stat. Ann. $\$ \mathrm{X}$ (Purdon)

Pa. Stat. Ann. tit. X, $\S X$

(Purdon)

(This is unofficial)

R.I. Gen Laws $\$ X$

S.C. Code $\$ X$

S.D. Comp. Laws Ann. $\subseteq X$

Tenn. Code Ann. $\$ \mathrm{X}$

Tex. [subject] Code Ann.

tit. X, \& X (Vernon)

Tex. Stat. Ann.

Utah

Vermont

Virginia

Washington

West Virginia W.Va.

Wisconsin

Wyoming
Wis.

Vt.

Va.

Wash.

Utah Code Ann. $\$ \mathrm{X}$

Vt. Stat. Ann. tit. X, $\$ \mathrm{X}$

Va. Code $\$ X$

Wash. Rev. Code $\$$ X

Wash. Rev. Code Ann. $\$$ X

W. Va. Code $\$ X$

Wis. Stat. $\$ X$

Wis. Stat. Ann. $\$ X$ (West)

Wyo.

Wyo. Stat. $\$ \mathrm{X}$ 19xx R.I. Pub. Laws

19xx S.C. Acts

19xx S.D. Sess. Laws

19xx Tenn. Pub. Acts

19xx Tex. Gen. Laws

$19 \times x$ IJtah Laws

19xx Vt. Acts

19xx Va. Acts

19xx Wash. Laws

19xx W. Va. Acts

$19 \mathrm{xx}$ Wis, Laws

19xx Wyo. Sess. Laws 


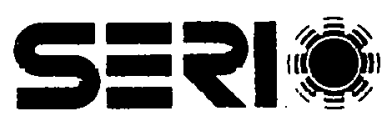

C-6 


\section{CITATION POINTERS}

See "A Uniform System of Citation," 12th ed. (1976), pp. 12-16, 50-60, 100-40.

Codes are preferable to Session Laws (SL). SL Code numbers are not always official.

Cite name of codification, subdivision (not if scattered) year in parentheses (varies with volume); give year(s) of original or replacement volume. If not published by the state, cite private publisher (even if official version).

Supplements: (Supp. 19xx). If necessary also cite main body of law in main volume.

Unofficial Codes: need to be cited only if statute does not appear in official code.

Session Laws: name of act (official, popular, or full date), public law or chapter number, volume or year, name of publication, page, year of enactment (unless in volume title).

Codifications: Example: "Solar Access Act," Ch. 1, $\$ 1,1979$ Colo. Sess. Laws.

Amended Statutes: Cite both acts if in different sources.

If citing amendment only, give original version parenthetically (amending).

Give relevant history if citing original (amended $19 x \mathrm{x}$ ).

Parallel sources: If source is not preferred, give parallel cite if available in tables.

Normally code citations use double capitals; large capitals for the first letter of each work, small capitals for the remaining letters. In contrast, session law references use regular (small) capitals only for the first letter. Where it is not feasible to use double capitals, regular capitalization of the entire code cite is recommended, but capitalization of only the first letter is permissible.

Regulations are often cited according to compilations of state administrative rules, which utilize differen part numbers for different agencies, (the names of which are usually abbreviated), followed by the regulation numbers. 
SEPI喽

C-8 


\section{TABLE C-1. PROPERTY TAX INCENTIVES}

SHACOB Solar heating and cooling of buildings. Includes controls, wiring, pumps, storage tanks, exchangers, etc. present in active collector systems.

Passive Structural elements absorbing and radiating solar thermal energy, of ten via nonmechanical systems. Examples include eaves, large thermal mass walls, roof ponds.

Hot Water Heating of water, as opposed to space heating.

Wind Wind energy conversion producing mechanical or electrical power.

Bio Bioconversion; commonly in the form of methane generation from agricultural products and wastes.

$\underline{\text { PV }} \quad$ Photovoltaics, the production of electricity directly from sunlight.

Hydro/Ocean Technologies ranging from water wheels, low-level water turbines, osmosis, temperature-gradient exploitation (especially in the ocean).

TE

Thermal-electric; electrical power produced from steam heating, usually by reflection of sunlight from heliostats into a central-station receiver.

Measurement Formulae - Exemption Equals:

(1) Total cost/value/price (C/V/P) (as assessed).

(2) Difference between $\mathrm{C} / \mathrm{V} / \mathrm{P}$ of solar and conventional systems.

(3) Lcoser of (3) and set dollar amiuint.

(4) Set percentage of $C / V / P$.

(5) Other - local variatioun or un!mually declining rate.

(6) Maximum assessment equals value of conventional system necessary to serve the building. 


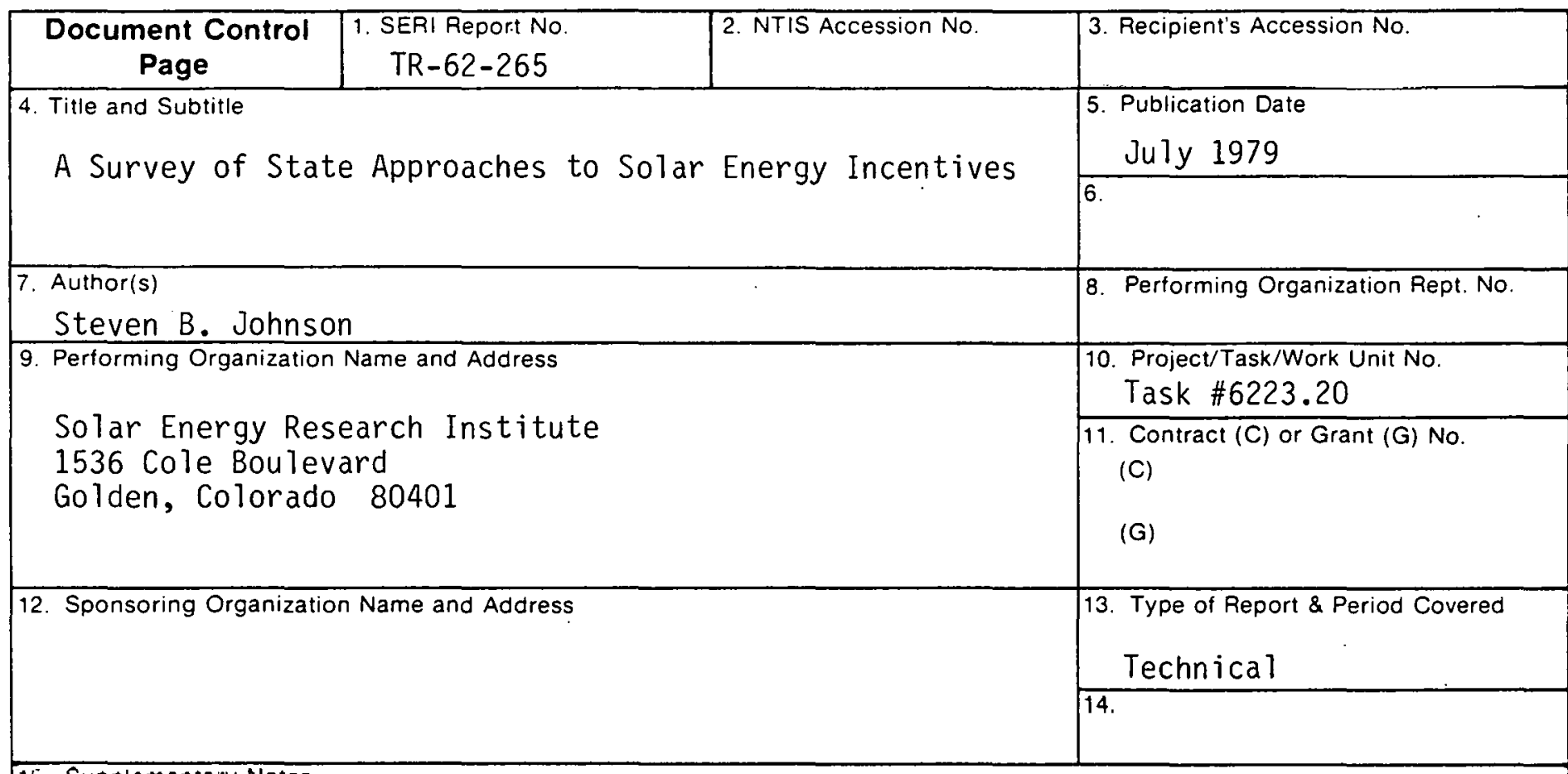

15. Supplementary Notes

16. Abstract (Limit: 200 words)

This article is a comprehensive survey of state statutes designed to encourage the application of solar technology. A large majority of the states have enacted financial incentives designed to stimulate solar energy use. Commonly, these incentives include preferential property tax treatment of solar systems, and income tax benefits to solar users. There are a wide variety of other tax breaks as well, including excise and franchise tax incentives. Some states have recently developed loan or grant programs for solar installations. Other states have addressed aspccts of real property and land-use planning law, which have served as barriers to eilher the installation of solar technology or access to sunlight. In addition to removing such obstacles as restrictive covenants and zoning limitations, the legislation of several states provides affirmative recognition of the potential of real property law to serve as a spur to solar development, through solar easements, planining and zonlng, and public nuisance. A small number of states have legislated in the field of utility regulation, addressing important questions of (1) nondiscriminatory rates for utility backup to solar systems and public utility commissions, and (2) utility involvement in solar energy applications.

17. Document Analysis

a. Descriptors Legislation; Laws; Legal Aspects; State Government; Regulations; Building Codes; Solar Rights; National Energy Act; Financial Incentives; Residential Buildings; Commercial Buildings; Public Utilities; Solar Cooling Systems; Solar Heating Systems; b.Identifiers/Open-Ended Terms Wind Power; Photovoltaic Cells; Hot Water Systems; Hydrothermal Systems; Ocean Thermal Energy Conver'sion; Biomass

c. UC Categories

59

18. Availability Statement

NTIS, U. S. Dept. of Commerce

5285 Port Royal Rd.

Springfield, VA 22161

\begin{tabular}{|c|c|}
\hline & No. of Pages \\
\hline & 106 \\
\hline & Price \\
\hline & $\$ 6.50$ \\
\hline
\end{tabular}

